$$
\text { Pontifícia Universidade C Católica }
$$

Elizabeth Freitas Rodrigues

A Economicidade dos Centros de Distribuição:
Uma análise para o varejo brasileiro

Tese de Doutorado

Tese apresentada ao Programa de Pós-Graduação em Engenharia de Produção da PUC-Rio como requisito parcial para obtenção do título de Doutor em Engenharia de Produção.

Orientador: Prof. Nélio Domingues Pizzolato

Rio de Janeiro

Outubro de 2013 


$$
\text { Pontifícia Universidade C Católica }
$$

Elizabeth Freitas Rodrigues

\section{A Economicidade dos Centros de Distribuição: Uma análise para o varejo brasileiro}

Tese apresentada como requisito parcial para obtenção do grau de Doutor pelo Programa de Pós-Graduação em Engenharia de Produção da PUC-Rio. Aprovada pela Comissão Examinadora abaixo assinada.

Prof. Nélio Domingues Pizzolato

Orientador

Departamento de Engenharia Industrial - PUC-Rio

Prof. Fernando Ramos Corrêa Departamento de Administração Industrial - CEFET-RJ

Prof. Luiz Felipe Roris Rodriguez Scavarda do Carmo

Departamento de Engenharia Industrial - PUC-Rio

Prof. Osvaldo Luiz Gonçalves Quelhas

Centro Tecnológico - UFF

Prof. Paulo Roberto Tavares Dalcol Departamento de Engenharia Industrial - PUC-Rio

Prof. José Eugenio Leal

Coordenador Setorial do Centro Técnico Científico - PUC-Rio

Rio de Janeiro, 03 de outubro de 2013 
Todos os direitos reservados. É proibida a reprodução total ou parcial do trabalho sem a autorização da universidade, da autora e do orientador.

\section{Elizabeth Freitas Rodrigues}

Bacharel em Administração, mestre em Gestão Tecnológica. É professora e pesquisadora do Centro Federal de Educação Tecnológica Celso Suckow da Fonseca - CEFET-RJ, no curso de graduação em Administração. Possui capítulos de livros, bem como artigos publicados em periódicos nacionais e internacionais.

Ficha Catalográfica

Rodrigues, Elizabeth Freitas

A economicidade dos centros de distribuição: uma análise para o varejo brasileiro / Elizabeth Freitas Rodrigues; orientador: Nélio Domingues Pizzolato. - 2013.

$111 \mathrm{f} . ; 30 \mathrm{~cm}$

Tese (doutorado) - Pontifícia Universidade Católica do Rio de Janeiro, Departamento de Engenharia Industrial, 2013.

Inclui bibliografia

1. Engenharia Industrial - Teses. 2. Logística. 3. Centros de distribuição. 4. Rede de varejo. I. Pizzolato, Nélio Domingues. II. Pontifícia Universidade Católica do Rio de Janeiro. Departamento de Engenharia Industrial. III. Título. 


\section{Agradecimentos}

Meu primeiro agradecimento é a Deus, Pai amado, que cuida de mim e me ampara sempre para que eu não tema o que está a minha frente. Obrigada Senhor, por tudo.

Ao estimado Prof. Dr. Nélio Domingues Pizzolato pela atenção, ensinamentos, e, por me orientar nesta tese de doutorado. Nélio, muito obrigada pela sua dedicação ao longo destes 04 anos de estudo.

Aos meus pais, pela orientação contínua, pela educação e caráter transmitidos.

Ao Julio, meu marido e amigo inseparável, pelo amor, apoio e compreensão.

À minha amada Lívia, simplesmente por existir. Obrigada pelo apoio, filha.

À minha família que procurava entender minhas ausências, devido à dedicação ao doutorado.

Ao CEFET-RJ e ao Departamento Acadêmico de Administração. Agradeço a todos os professores pelo apoio e incentivo que me deram nesta jornada.

Ao Departamento de Engenharia Industrial da PUC-RIO, pela oportunidade que me foi concedida em cursar o Programa de Pós-Graduação em Engenharia de Produção.

Aos Professores e Funcionários do Departamento de Engenharia Industrial, pela dedicação, amizade, e bate-papos que sempre animavam os meus dias na PUC. 


\section{Resumo}

Freitas Rodrigues, Elizabeth; Pizzolato, Nélio Domingues (Orientador). A Economicidade dos Centros de Distribuição: Uma análise para o varejo brasileiro. Rio de Janeiro, 2013. 111p. Tese de Doutorado Departamento de Engenharia Industrial, Pontifícia Universidade Católica do Rio de Janeiro.

As grandes redes do varejo revolucionaram seus sistemas logísticos posicionando Centros de Distribuição - CDs - perto aos grandes centros urbanos. Esta estratégia possibilitaria mantê-los próximos aos pontos de venda para um rápido ressuprimento, por proporcionar condições favoráveis para lidarem mais facilmente com os problemas de tráfego crescente, que restringem o acesso dos grandes caminhões aos centros urbanos e, além disso, associado a um amplo espectro de motivos, visava à otimização dos processos logísticos. O presente estudo tem como objetivo mensurar os benefícios econômicos resultantes desta nova estratégia logística implementada por organizações de varejo na adoção de Centros de Distribuição. Estes ganhos estão relacionados com os seguintes fatores: (i) redução nos custos de transporte originados dos fornecedores, (ii) redução de custos operacionais e de estoque, (iii) liberação de espaço nobre nas lojas para a exposição de mercadorias e estacionamento, (iv) redução de mão de obra devido à centralização dos controles dos produtos recebidos, e (v) redução da incidência da falta de produto. Por outro lado, a cadeia de varejo internaliza alguns custos relativos à operação do Centro de Distribuição, como os custos operacionais do $\mathrm{CD}$ e os de transporte de mercadorias deste às lojas. Este estudo qualifica esses fatores apoiando-se em literatura científica e quantifica esses custos de maneira empírica.

\section{Palavras-chave}

Logística; Centros de Distribuição; Rede de Varejo. 


\section{Abstract}

Freitas Rodrigues, Elizabeth; Pizzolato, Nélio Domingues (Advisor). The economy of distribution centers: an analysis for the Brazilian retail. Rio de Janeiro, 2013. 111p. DSc. Thesis - Departamento de Engenharia Industrial, Pontifícia Universidade Católica do Rio de Janeiro.

Large retail chains have revolutionized their logistics systems positioning Distribution Centers - CDs - near large urban centers. This strategy would enable them to stay close to the outlets for a quick resupply, by providing favorable conditions in order to deal more easily with the growing traffic problems, which restrict access of large trucks to urban centers, and furthermore, associated with a wide spectrum of reasons, aimed to the optimization of logistics processes. The present study aims to measure the economic benefits of this new logistics strategy implemented by retail organizations in the adoption of Distribution Centers. These gains are related to the following factors: (i) reduction in transportation costs arising from suppliers, (ii) reduction of inventory and operating costs, (iii) release of prime space in stores for parking and display of goods, (iv)reduction of manpower due to the centralization of control of incoming goods, and ( $v$ ) reduction of stock-outs. On the other hand, the retail chain internalizes some costs related to the operation of the distribution center, as operating costs, and freight from the $\mathrm{CD}$ to the stores. This study describes these factors relying on scientific literature and quantifies these costs empirically.

\section{Keywords}

Logistics; Distribution Centers; Retail Network. 


\section{Sumário}

1. Introdução 12

$\begin{array}{ll}\text { O problema } & 13\end{array}$

1.1. Objetivos 17

1.2. Caracterização da pesquisa 18

1.3. Organização do Trabalho 21

2. Fundamentaç 23

2.1. O Gerenciamento da Cadeia de Suprimentos (Supply Chain 25

$\begin{array}{ll}2.1 .1 . \text { Estrutura conceitual de um SCM } & 29\end{array}$

2.1.2. Processos de negócios na cadeia de suprimentos 32

2.1.3. Os componentes gerenciais do SCM 35

$\begin{array}{ll}\text { 2.2. Logística } & 37\end{array}$

2.2.1. Custos Logísticos 41

3. A análise de economicidade de um Centro de Distribuição - uma estrutura analítica $\quad 50$

3.1. Informações sobre o varejo brasileiro e a empresa estudada 52

3.2. A empresa - seus processos gerenciais e componentes de gestão 57

3.3. Elementos que promovem redução de custos 62

3.3.1. Redução no custo de transporte 64

3.3.2. Redução no custo do estoque $\quad 67$

3.3.3 Aumento do espaço nobre nas lojas

3.3.4 Centralização de controles e redução de mão de obra nas lojas 76

3.3.5. Redução da incidência da falta de produto 78

4. A aplicação da estrutura Analítica - Uma empresa do Varejo $\begin{array}{ll}\text { Brasileiro } & 81\end{array}$

4.1. Quantificação dos ganhos decorrentes da implantação de um CD 81

4.1.1 Redução no custo do transporte $\quad 81$

4.1.2 Redução no custo do estoque $\quad 84$

4.1.3. Aumento no espaço nobre das lojas $\quad 86$

4.1.4. Redução do custo com mão-de-obra $\quad 88$

4.1.5. Redução da falta de produto 92

5. Conclusão e resultados obtidos $\quad 97$

5.1. Contribuição da pesquisa 102

5.2. Sugestões de prosseguimento da pesquisa 103

$\begin{array}{ll}\text { Referências bibliográficas } & 105\end{array}$

Apêndice 1: Demonstrativo de correlação e variância - Produto $\begin{array}{ll}\text { Higiene pessoal } & 110\end{array}$

Apêndice 2: Demonstrativo de correlação e variância - Produto Refrigerante 


\section{Lista de Figuras}

Figura 1: Estrutura de análise de redução de custos em um CD 16

$\begin{array}{ll}\text { Figura 2: A estrutura da cadeia de suprimentos } & 27\end{array}$

Figura 3: Framework do gerenciamento da cadeia de suprimentos 30

Figura 4: Gerenciamento da cadeia de suprimentos: integrando e gerenciando processos de negócios na cadeia de suprimentos

Figura 5: Framework de logística integrada 40

Figura 6: Fatores que compõem os Custos logísticos $\quad 42$

$\begin{array}{ll}\text { Figura 7: Políticas de abastecimento } & 46\end{array}$

Figura 8: Fatores satélites da cadeia de suprimentos $\quad 63$

Figura 9: Comparativo entre $\mathrm{n}^{\circ}$ de viagens com e sem CDs 66

$\begin{array}{lr}\text { Figura 10: Política de ressuprimento adequada } & 69\end{array}$

$\begin{array}{ll}\text { Figura 11: O lote econômico de compra } & 70\end{array}$

Figura 12: Mapa da cidade do Rio de Janeiro - Valor do $\mathrm{m}^{2}$

Figura 13(a) e (b): Área de lojas e estacionamento antes e depois dos CDs 


\section{Lista de Tabelas}

Tabela 1: Composição de custos e margem de uma empresa industrial típica

Tabela 2: Distribuição dos investimentos da empresa controladora

Tabela 3: Preço médio de frete $(\mathrm{R} \$)$

Tabela 4: Economicidade após instalação do CD 


\section{Lista de Gráficos}

Gráfico 1: Curva bibliográfica consultada 20

Gráfico 2: Evolução área de vendas x $n^{\circ}$ lojas $\quad 55$

Gráficos 3(a) e 3(b): Informativos financeiros da empresa estudada 55

Gráfico 4: Redução no custo total do frete 84

Gráfico 5: Redução no Custo Total do $\mathrm{m}^{2}$ nas lojas e nos CDs 87

Gráfico 6: Redução do custo de Mão de obra das Lojas x CD 91

Gráfico 7: Comportamento da demanda anual do produto analisado $\begin{array}{ll}\text { (higiene pessoal) } & 94\end{array}$

Gráfico 8: Comportamento da demanda anual do produto analisado (refrigerante) 


\section{Lista de Siglas e Abreviaturas}

A - custo de encomendar cada pedido

CD - Centros de Distribuição

CLM - Council of Logistic Management

CPDS - Council for Physical Distribution System

CRM - Customer relationship management

CSCMP - Council of Supply Chain Management Professionals

CT - custo total administrável dos estoques em uma loja

$\mathrm{CT}_{\mathrm{CD}}$ - custo total administrável dos estoques concentrados em um $\mathrm{CD}$

$\mathrm{CT}_{\mathrm{n}}$ - custo total administrável dos estoques do conjunto $n$ de lojas

D - demanda anual observada em uma loja

EBITDA - Earnings Before Interest, Taxes, Depreciation and Amortization

EDI - Electronic Data Interchange

EOQ ou LEC - Lote Econômico de Compra

ERP ou SAP/ERP - Enterprise resource planning

FIPE - Fundação Instituto de Pesquisas Econômicas

GSCF - Global Supply Chain Forum

$\mathrm{h}$ - custo de manter em estoque por unidade-ano

IBGE - Instituto Brasileiro de Geografia e Estatística

ILOS - Instituto de Logística e Supply Chain

LT - Lead Time

PDV - Ponto de Venda

PIB - Produto Interno Bruto

Q - lote econômico

$\mathrm{Q}^{*}=$ quantidade ótima de cada pedido

SCM - Supply Chain Management

SRM - Supplier Relationship Management

TIC - Tecnologia da informação e comunicação

VMI - Vendor managed inventory 


\section{1 \\ Introdução}

A necessidade de suprir adequadamente os variados e dispersos pontos de vendas, e melhor gerenciar todo o processo de recebimento de produtos de uma multiplicidade de fornecedores, levou as organizações envolvidas com o varejo ao desenvolvimento de procedimentos centralizados, resultando em uma distribuição mais eficiente, flexível, dinâmica e notavelmente mais econômica. As vantagens decorrentes da adoção de Centros de Distribuição (CD), ao lado de sua simplicidade lógica, sugerem que, depois de implantado por uma empresa, tenha passado a ser adotado pelas demais, devido a suas imensas vantagens operacionais, profundas repercussões nas rotinas correntes e significativas reduções nos custos administrativos.

Muitos são os fatores que colaboram para concretização da centralização de estoques através de Centros de Distribuição. Dentre eles destaca-se a evolução da Tecnologia da Informação e Comunicação - TIC - que possibilitou o desenvolvimento de sistemas de informação, que aliados a processos complementares permitem uma armazenagem eficiente. As grandes empresas, principalmente varejistas, executam projetos de localização de centros de distribuição a fim de alcançarem redução de custos em seus estoques e distribuição e, da mesma forma, aumentarem o nível de satisfação do cliente que é atendido mais rapidamente, não se defrontando com a falta de produtos nos pontos de venda finais.

O gerenciamento da distribuição física é um dos mais antigos característico desafio logístico, no qual a empresa deve planejar o atendimento dos seus clientes que estão dispersos geograficamente. Estudos sobre localização de Centros de Distribuição, assim como modelos heurísticos para estas localizações são diversos, e os primeiros trabalhos remetem à década de 60, como: KUEHN \& HAMBUERGER (1963); EFROYMSON \& RAY (1966); SPIELBERG (1969).

Os estoques têm representado um dos maiores desafios para as organizações, mas o uso do CD oferece uma oportunidade para melhorar o seu gerenciamento. As empresas, dentro de seus ambientes de negócios, buscam 
reduzir os custos com estoques e simultaneamente melhorar o nível de serviço oferecido ao cliente, e a implantação de um CD é, justamente, uma decisão crítica, pois tem por objetivo achar um equilíbrio entre estes dois fatores, a saber: a redução dos estoques e a melhora no nível de serviço (DASKIN \& COULLARD, 2002).

Um CD permite a consolidação dos estoques que existem nos diversos pontos de venda de uma rede varejista, os quais ocupam espaços que poderiam ter utilização mais nobre. Essa transferência promove um significativo ganho operacional, com forte impacto na redução dos custos e ganhos de eficiência. Por outro lado, o CD exige um importante aperfeiçoamento dos sistemas de informação e intenso envolvimento de parceiros logísticos responsáveis pela alimentação dos produtos e serviços, e subsequente abastecimento das lojas.

Diante das considerações anteriores emergem diversos fatores econômicos a serem considerados ao analisar as vantagens advindas da implantação de um CD, pois este promove reduções em diversos tipos de custos da rede, como: (i) redução nos custos de transporte originados dos fornecedores, (ii) redução de custos de estoque, (iii) liberação de espaço nobre nas lojas para a exposição de mercadorias e estacionamento, (iv) diminuição do manpower utilizado para recepção e armazenagem de mercadorias nas lojas, em razão de um processo que apresenta significativos ganhos em escala, e ( $v$ ) redução da incidência da falta de produto. Esses fatores são detalhados neste trabalho, com o objetivo de demonstrar e quantificar as significativas vantagens dos CDs.

\section{O problema}

A economia mundial, assim como as corporações estão sofrendo grandes transformações devido a uma série de fatores, a saber: terceirização, necessidades de implementação de processos lean e, também a globalização. Para sobreviver à nova ordem econômica, as empresas precisam adaptar-se a esta realidade, na qual o sucesso de uma organização individual está relacionado com sua habilidade em competir, desempenhando diferentes papéis nas cadeias de suprimento dinâmicas. Assim, o gerenciamento da cadeia de suprimentos tornou-se uma iniciativa 
estratégica para as organizações que pretendem aumentar seu potencial competitivo (CHING, 1999).

As recentes reivindicações do cliente final como tecnologia, preço, qualidade e serviço geram uma reação em cadeia, exigindo das empresas parceiros competitivos, flexíveis e com domínio tecnológico, para atender essas necessidades. Entende-se que os fatores flexibilidade, domínio da tecnologia e competitividade devem ser observados pelas organizações e seus gestores, a saber: (i) a flexibilidade para atender às variações de demanda de mercado e garantir a entrega contínua do produto de acordo com o prazo; (ii) o domínio de tecnologia para se informar das novidades tecnológicas e de outros produtos no mercado; e (iii) a competitividade, para que seja possível a permanência no mercado interno e externo, em um contínuo processo de superação da concorrência.

O desempenho das atividades de suprimentos e de distribuição depende da otimização da rede logística, que é alcançada com base na análise estratégica da organização. Uma vez definida a quantidade e o posicionamento das instalações em uma rede logística, toda a operação de transporte e distribuição dos produtos estará condicionada a esta configuração. Desta forma, as decisões estratégicas sobre instalações influenciam o desempenho e a eficiência da cadeia de suprimentos, a rentabilidade da empresa e definem ainda a estrutura física do sistema logístico. Todas estas características devem ser mensuradas e indicadores devem ser avaliados para reduzir as incertezas sobre a operacionalidade do sistema logístico e a consequente centralização - objeto de estudo deste trabalho tornando-se um fator viável e rentável para a empresa.

De acordo com Mintzberg et al. (2003), uma estratégia bem formulada ajuda a ordenar e alocar os recursos de uma organização para uma postura singular e viável, com base em suas competências e deficiências internas e aliado a uma visão antecipatória do ambiente externo, providências contingentes são realizadas em relação a oponentes inteligentes.

Segundo Porter (1981), a concorrência é o fator determinante do sucesso ou do fracasso de uma organização, determinando como a adequação de suas atividades, ao longo de toda a cadeia de valor, irá contribuir para o seu desempenho. Desta forma, traçar objetivos que sejam conectados a missão da 
empresa, assim como desdobrar tais objetivos em indicadores mensuráveis, faz-se necessário para o bom gerenciamento de qualquer negócio.

Silva (2006) ressalta que sistemas de gestão estratégica devem desdobrarse em metas e, consequentemente, indicadores que mostrem coerência entre os parâmetros mensurados, fatores críticos da empresa, suas estratégias competitivas, metas e objetivos estratégicos adotados.

Kaplan \& Norton (1997) afirmam que o objetivo de um sistema de mensuração deve ser o de motivar os executivos e colaboradores a implementarem com sucesso a estratégia nas unidades de negócio. Desta forma, as empresas que conseguem traduzir a estratégia em indicadores conseguem explicitar quantitativamente seus objetivos e metas.

Sem medições não é possível garantir que o desempenho seja o desejado, enquanto que, com medições erradas corre-se o risco de sub-otimizar o desempenho de todo o sistema. (RUMMLER \& BRACHE, 1994).

Com base no que estes autores citam, vale deixar claro que medições erradas podem até levar à ineficiência, pela aplicação de investimentos exacerbados sobre fatores irrelevantes.

Martins \& Teóphilo (2000) apresenta as características que um sistema de mensuração de desempenho deve possuir: ser congruente com a estratégia competitiva; ter medidas financeiras e não financeiras; direcionar e suportar a melhoria contínua; identificar tendências e progressos; facilitar o entendimento das relações de causa e efeito; ser inteligível para os colaboradores; abranger todo o processo, desde o fornecedor até o cliente; ter as informações disponíveis em tempo real, para toda a organização; ser dinâmico; influenciar a atitude dos colaboradores; proporcionar a avaliação do grupo e não somente o indivíduo isoladamente. A vantagem competitiva deve acontecer como consequência deste gerenciamento.

Segundo Barney \& Hesterly (2011), vantagem competitiva é a capacidade de uma empresa gerar maior valor do que as suas concorrentes, sendo este a diferença entre os benefícios percebidos por um cliente que compra os seus produtos ou serviços e o custo econômico total desses. Portanto, o tamanho da vantagem competitiva de uma empresa é a diferença entre o valor econômico que ela consegue criar e aquele apresentado por seus rivais. 
Diante do exposto, pergunta-se:

a) Existe atualmente na literatura um modelo descritivo que aborde os cinco fatores de redução de custo antes citados, de forma consolidada, para análise de economicidade de um centro de distribuição?

b) É possível evidenciar a economicidade de tais indicadores para um exemplo aplicado a uma rede de varejo?

A estrutura analítica-descritiva:

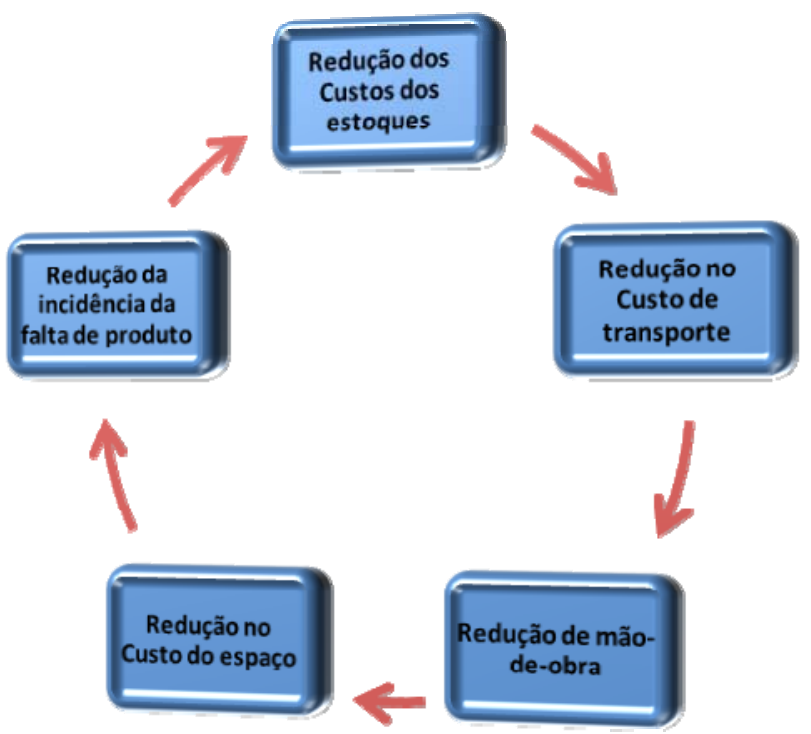

Figura 1: Estrutura de análise de redução de custos em um CD. Fonte: a autora

A autora escolheu o modelo de Lambert et al (1998) por este melhor evidenciar a cadeia de suprimentos da empresa focal para o objetivo pretendido neste trabalho, em detrimento de modelos trazidos por outros autores.

É importante ressaltar que, de acordo com a cadeia de suprimentos proposta por Lambert et al. (1998), este trabalho somente analisará o primeiro nível da cadeia à montante e à jusante da empresa focal. 


\section{1}

\section{Objetivos}

A distribuição física é parte de um conjunto integrado de decisões que envolvem níveis de serviços aos clientes, padrões de estoque, organização do transporte e políticas de compras e vendas. Todo esse conjunto de decisões visa prover um fluxo eficiente de materiais e produtos ao longo de toda a cadeia de suprimentos em direção aos clientes.

Algumas empresas se defrontam com a decisão estratégica quanto ao número de CDs a implantar, sua localização e quais clientes atender a partir de cada um deles. Segundo Erlebacher \& Miller (2000), um dos objetivos que a empresa deve avaliar é o de manter um nível de serviço aceitável, mas minimizando os custos operacionais do $\mathrm{CD}$, os custos dos estoques de segurança, os custos de transporte entre fornecedores e CDs, e destes aos clientes finais.

$\mathrm{Um} \mathrm{CD}$, em especial, assume diversas funções que seriam exercidas pelas múltiplas lojas, desde a de centralizador das compras e do relacionamento com os fornecedores até as funções de receptor, controlador de produtos comprados e seu armazenamento, para posterior entrega a sua rede de lojas, quando se tornar necessário repor os produtos consumidos pelos clientes finais. Em todas as funções desempenhadas pelo $\mathrm{CD}$ existe um ganho de escala, ao concentrar atividades dispersas pelas lojas em uma única instalação.

Para as redes de varejo, que gerenciam as lojas e os seus fornecedores, a transferência do recebimento dos produtos e sua estocagem para pontos centrais CDs - promove ganhos diversos.

Este trabalho tem como objetivo evidenciar cinco indicadores que a literatura ${ }^{1}$ coloca como relevantes para a análise da economicidade de um Centro de Distribuição, a saber:

(i) redução nos custos de transporte originados dos fornecedores,

(ii) redução de custos de estoque e custos operacionais,

(iii) liberação de espaço nobre nas lojas para a exposição de mercadorias e estacionamento,

\footnotetext{
${ }^{1}$ Starr \& Miller (1962); Maister (1976); Eppen (1979)
} 
(iv) redução de mão de obra devido à centralização dos controles dos produtos recebidos, e

(v) redução da incidência da falta de produto.

Como objetivos específicos têm-se:

(i) entender, com base na literatura, os modelos e técnicas matemáticas que comprovem a economicidade de um Centro de Distribuição.

(ii) descrever como os custos operacionais de um CD se comparam aos custos correspondentes nas lojas e demonstrar sua economicidade.

(iii) realizar uma comparação tanto analítica como empírica entre o modelo de entrega direta loja-a-loja e o modelo de distribuição feita através de um $\mathrm{CD}$, comprovando o ganho deste último.

(iv) analisar os resultados obtidos, de modo a estabelecer conclusões em relação à sua eficiência, precisão, praticidade e aplicabilidade.

Ao evidenciar o estado da arte sobre tais indicadores, este trabalho demonstra, através de um exemplo do varejo brasileiro, que tais indicadores podem ser aplicados a uma rede com aproximadamente 100 lojas, centralizadas em um único Centro de Distribuição. Além da aplicação, este estudo também quantifica e evidencia as reduções de custos proporcionadas por estes indicadores.

O exemplo de varejo discutido nesta tese não chega a atingir um estudo de caso, pois não ocorreu o acesso privilegiado a nenhuma empresa. Entretanto, os relatórios divulgados por grandes empresas permitem indicações diretas de diversos parâmetros. Adicionalmente, muitas apurações indiretas, mormente nas tarifas de transporte, foram obtidas, como sintetizado na seção 1.2..

\section{2}

\section{Caracterização da pesquisa}

De acordo com os critérios de classificação de pesquisa propostos por Gil (2009) e por Vergara (2007), quanto aos objetivos, esta pesquisa pode ser classificada como exploratória, pois estuda mais profundamente um assunto pouco explorado, no que diz respeito à evolução do modelo de análise de economicidade, com a consolidação de diversos indicadores já apresentados por 
autores renomados, mas que agora se compilam em uma estrutura analítica.

A pesquisa exploratória parte do mesmo princípio das demais que necessitam de uma pesquisa bibliográfica, pois haverá sempre uma experiência prática com problemas semelhantes ou uma análise de exemplos análogos que podem estimular a compreensão, além de uma pesquisa de campo com a aplicação a entrevistas (GIL, 2009)

Esse tipo de pesquisa geralmente tende à forma de um estudo aplicado, por ser específico e consistir na análise de uma unidade de estudo como o exame detalhado de um ambiente, de um sujeito ou de uma situação em particular (NEVES, 1996). Este estudo aplica-se a uma única empresa do varejo situada na cidade do Rio de Janeiro

No que concerne à pesquisa da empresa de varejo brasileira, apresenta também características de uma pesquisa descritiva, pois objetiva expor as características de um determinado fenômeno - o impacto da centralização em uma rede de lojas - bem como estabelecer correlações entre variáveis - custo e tempo.

Baseia-se em fontes múltiplas de evidência - primárias e secundárias - e se beneficia do desenvolvimento prévio de proposições teóricas para direcionar a coleta e a análise dos dados.

O estudo documentado nesta pesquisa está circunscrito a um Centro de Distribuição localizado no Rio de Janeiro que centraliza os estoques de aproximadamente 100 lojas de uma rede varejista. A análise volta-se somente para o modelo de distribuição direta e cross-docking, não analisando outras formas que também influenciam os processos de distribuição, como VMI Vendor Managed Inventory -, a postergação, entre outros, e também não avalia produtos perecíveis de baixo ciclo.

Tem suporte de um levantamento documental e de uma pesquisa bibliográfica envolvendo um estudo sistematizado desenvolvido com base em periódicos, livros, teses e dissertações, artigos científicos da época e recentes.

O Gráfico 1 demonstra a curva das referências bibliográficas consultadas neste trabalho de pesquisa, onde é possível evidenciar uma distribuição que apresenta a consolidação do conhecimento sobre o assunto estudado. Foram utilizadas as seguintes palavras-chave para esta pesquisa: localização de depósitos/centros de distribuição; custos de transporte e de armazenagem. 
Foi também utilizada documentação interna da empresa - tanto material de domínio público como os encontrados em seu website, além de entrevistas informais, pouco estruturadas, com o objetivo de colher informações dos gerentes de nível tático da empresa focal.

Para entender também a dinâmica do setor, algumas entrevistas foram feitas com pessoas relacionadas à cadeia de suprimentos da empresa focal.

De acordo com a mesma taxionomia, a investigação é ex post facto, pois se refere a um fato já ocorrido no momento da pesquisa, impossibilitando qualquer controle ou manipulação das variáveis sob estudo.

De acordo com a caracterização de Gil (2009), a abordagem metodológica da pesquisa é qualitativa, pois por meio de uma observação cuidadosa, e algumas antecipações ou suposições sustentáveis, procura-se entender as leis que regem o varejo, assim como a decisão pela centralização de estoques.

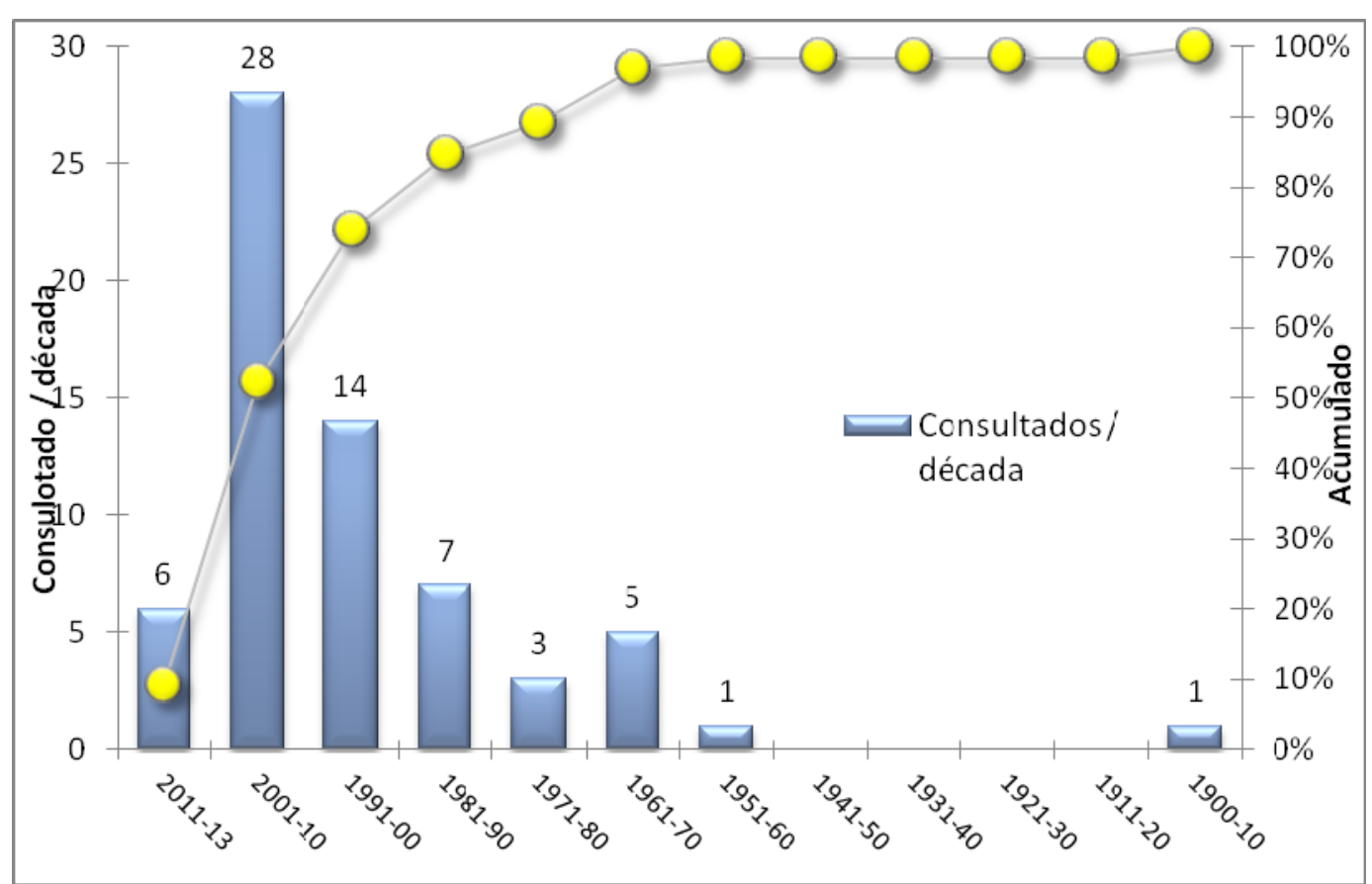

Gráfico 01: Curva bibliográfica consultada. Fonte: A autora 


\section{3}

\section{Organização do Trabalho}

Esta dissertação está organizada em cinco capítulos. Este Capítulo introdutório apresenta a contextualização do sistema logístico e a problemática do assunto a ser analisado. Expõem-se os diversos problemas envolvidos na análise da economicidade quando da centralização de estoques através de Centros de Distribuição, pontuando assim a relevância do tema escolhido. Demonstram-se ainda as razões de efetuar um estudo sobre a economicidade dos Centros de Distribuição, sendo listadas as justificativas da pesquisa. E ainda, abordam-se os objetivos do estudo, delimitando-se os pontos que se pretende pesquisar. $\mathrm{O}$ Capítulo apresenta ainda a exposição da metodologia e da estrutura do trabalho.

O Capítulo 2 apresenta a revisão teórica baseada na bibliografia relevante para o tema em questão, abordando os conceitos básicos da logística, dos custos logísticos e dos Centros de Distribuição.

O Capítulo $3^{2}$, também pautado na bibliografia, apresenta os fatores relevantes na análise de uma implantação de Centros de Distribuição, demonstrando os pontos fundamentais para a análise econômica de tais instalações. São apresentados ainda modelos matemáticos a serem utilizados para a demonstração da economicidade. Através de uma estrutura analítica formulada com este propósito, cinco indicadores são avaliados, a saber: (i) redução dos custos do transporte originado nos fornecedores; (ii) redução dos volumes e custos de estoque; (iii) aumento de espaço nas lojas destinado à exposição de mercadorias e estacionamento; (iv) redução da mão de obra pela centralização dos controles sobre os produtos recebidos; e (v) redução de back-orders.

O Capítulo $4^{3}$ demonstra a aplicabilidade da estrutura de análise através de um exemplo extraído de uma rede de varejo brasileira que têm seus estoques centralizados e gerenciados através de um único Centro de Distribuição.

O Capítulo 5 constitui-se das conclusões e considerações finais da tese, buscando responder a questão central de pesquisa, expressa no objetivo geral deste trabalho. Os objetivos específicos também são abordados e evidenciados de

\footnotetext{
2 Os fatores descritos no Capítulo 3 foram parcialmente publicados no artigo Rodrigues \& Pizzolato (2013a).

${ }^{3}$ Os resultados obtidos no Capítulo 4 foram parcialmente publicados no artigo Rodrigues \& Pizzolato (2013b).
} 
forma a dar os subsídios necessários para responder à questão central da tese. São feitas ainda sugestões para prosseguimento futuro da pesquisa. 


\section{2}

\section{Fundamentação Teórica}

O aumento da competição global e a fusão das grandes empresas vêm imprimindo um novo cenário às organizações que buscam, continuamente, o controle de seus custos, tentando ao mesmo tempo otimizar a localização de suas instalações e ampliar sua eficiência operacional. Gerenciar suas Cadeias de Suprimentos, além de proporcionar uma visão integrativa, possibilita às organizações gerenciar materiais e fluxos de informação com fornecedores e clientes, bem como entre as diferentes áreas dentro da empresa.

Esta revisão inicia-se evidenciando o estudo de consolidação de estoques em Centros de Distribuição. Tal revisão não pretende trazer à tona todo o conhecimento a este respeito, mas tão somente indicar linhas de pesquisa já desenvolvidas por autores notórios na área.

Atualmente, muitas organizações utilizam-se da estratégia de estabelecer Centros de Distribuição devido às vantagens decorrentes destes, as quais são objeto de identificação e quantificação neste trabalho. De acordo com BALLOU (2001), o CD é uma configuração de armazém onde são recebidas cargas consolidadas de diversos fornecedores; essas cargas são fracionadas a fim de agrupar os produtos em quantidade e sortimento precisos e então, encaminhadas para os pontos de venda que pertencem ao seu espaço de atendimento.

As funções básicas de um CD, segundo CALAZANS (2001), são: recebimento, movimentação, armazenagem, separação de pedidos e expedição. A mercadoria chega do fornecedor e é recebida pelo $\mathrm{CD}$, podendo ser armazenada para futura expedição ou ser expedida diretamente, o que é chamado de crossdocking - operação na qual o produto é recebido e encaminhado diretamente para o cliente - com o mínimo de tempo possível, a fim de não mantê-lo em estoque. Quando destinada à armazenagem, a mercadoria é movimentada para seu determinado local no estoque, até que seja solicitada através de um pedido; naquele momento então é separada e encaminhada para expedição, onde é transportada até o destino estabelecido. 
Quando a pesquisa sobre Centros de Distribuição é direcionada para o trade-off entre custos de transporte, custos de armazenagem e nível de serviço, muitos são os estudos desenvolvidos que demonstram os benefícios desta centralização. Eppen \& Schrage (1981) modelam um sistema de armazéns onde há uma distribuição normal de demanda, custos de armazenagem e de backorder proporcionalmente idênticos e sem evidências de transbordo. $\mathrm{O}$ modelo proposto pelos autores utiliza-se de uma política de operação revista periodicamente e sem estoques de manutenção, onde o sistema consiste em um $\mathrm{CD}$ que não mantém estoques, mas que os aloca nos varejistas utilizando um framework baseado no modelo de multi-periods newsvendor. Schwarz (1981) demonstra os benefícios de consolidar estoques em um framework de Lote econômico de multi-depósitos.

Em outra linha, Erlenbacher \& Meller (2000) desenvolvem um modelo analítico que objetiva estabelecer o número ideal de Centros de Distribuição, sua localização, bem como quais clientes servir, minimizando assim os custos fixos de operação do $\mathrm{CD}$, custos de estoque, custo de transporte entre as plantas e os CDs, mantendo níveis aceitáveis de serviço ao cliente. Effroyson \& Ray (1966) consideravam o problema de determinar o número e alocação dos CDs com o objetivo de minimizar os custos fixos e de transporte associado ao $\mathrm{CD}$, e atender um grupo de clientes localizados em pontos dispersos.

Entretanto, vale aqui trazer à tona alguns conceitos relevantes $\mathrm{e}$ contemporâneos na literatura que possibilitarão o entendimento da utilização, economicidade e características da operação de um Centros de Distribuição.

Apesar do conceito de Centro de Distribuição anteceder o conceito de SCM - Supply Chain Management -, faz-se necessário apresentá-lo, pois devido a um pensar sistêmico das organizações, os CDs atualmente são gerenciados partindo do pressuposto que há toda uma Cadeia de Suprimento a sua volta que deve ser estabelecida em conjunto e gerida como uma rede de múltiplos negócios.

Desta forma, é necessário abordar o que a literatura apresenta sobre SCM e suas características. 


\section{1}

\section{O Gerenciamento da Cadeia de Suprimentos (Supply Chain Management)}

A literatura não traz um marco histórico definindo o surgimento do termo Supply Chain Management - SCM. No início dos anos 1980, o termo começou a ser utilizado para descrever uma mistura e renomeação de atividades já estabelecidas nos negócios, principalmente as atividades de logística e gerenciamento de produção (PECK, 2005).

Com o passar dos anos novas atividades foram incluídas e seu conceito foi estendido, incluindo os aspectos de marketing, desenvolvimento de novos produtos, gerenciamento de pedido e pagamento (COOPER et al., 1997). Porém, a clareza sobre seu significado só ocorre no final da década de 90, especialmente no mundo acadêmico. Apesar da clareza estabelecida, é ainda um conceito em evolução e cuja utilização se restringe a um conjunto de empresas mais avançadas (WANKE et al., 2011).

O movimento de SCM surge a partir da valorização das atividades logísticas nas empresas. Embora tais atividades fossem praticadas pelos indivíduos há muitos anos, originariamente com fins militares (Ballou, 2001; Pires, 2004), até a década de 80/90 a logística tinha status secundário nas empresas industriais.

Somente com a revolução da tecnologia da informação; do desenvolvimento e gestão de alianças e parcerias com fornecedores e distribuidores; dos produtos com ciclos de vida reduzidos; da intensa competição nos mercados globais e do surgimento de novos modelos de produção, foi que a logística surge como fonte de vantagens competitivas (BOWERSOX, 1996; SIMCHI-LEVI et al.,2003).

As atividades logísticas nas empresas, que nos primórdios só abrangiam atividades de transporte e armazenagem, passam também a executar atividades como controle de estoques, embalagem, processamento de pedidos e manuseio de materiais. A expansão das atividades logísticas possibilitou, inicialmente, a integração interna com outras funções da empresa, principalmente marketing e produção. Essa primeira etapa é conhecida como a evolução do conceito de logística integrada, e que atualmente está bastante consolidada nas organizações produtivas (WANKE et al., 2011). 
O gerenciamento da cadeia de suprimentos é uma área rica em desafios que tem atraído crescente interesse de economistas, administradores, engenheiros, matemáticos, entre outros profissionais. O principal desafio imposto pelo SCM consiste, basicamente, em integrar processos e estruturas de tomada de decisão cujo universo de abrangência engloba várias organizações, muitas vezes com interesses antagônicos.

Uma estrutura integrada de tomada de decisão deve ser realizada por meio da administração compartilhada de processos-chave de negócios, que interligam as diversas unidades organizacionais da cadeia, exigindo uma eficiente coordenação funcional e temporal de empresas e clientes.

O desafio da integração presente no SCM pode ser enfrentado considerando a cadeia de suprimentos como uma entidade única, cujos programas de planejamento e de atuação têm sido modelados nas mais diversas áreas de interesse, com vistas à otimização global do sistema. Existem na literatura vários tipos de abordagens para modelar o planejamento conjunto e colaborativo da cadeia de suprimentos, conforme segue.

A cadeia de suprimentos - supply chain - é responsável por todos os estágios envolvidos, direta ou indiretamente, na obtenção, produção e liberação de um determinado produto/serviço ao cliente final, sendo formada por uma rede de empresas autônomas, ou semi-autônomas, que agregam valor ao produto/serviço, e tem como objetivo maximizar o valor global gerado (CHOPRA \& MEINDL, 2004).

Para Peck (2006), a cadeia de suprimentos compreende o fluxo de materiais, bens e informações, que passam dentro e entre as organizações, ligados por um leque de facilitadores tangíveis e intangíveis, incluindo relacionamentos de processos, atividades e sistemas integrados (informação), sendo que na prática são ligados por redes de transporte físico e de distribuição, e infra-estrutura de comunicação e transporte.

Uma representação linear de uma cadeia de suprimentos pode ser vista na Figura 2. Essa figura que representa a empresa foco tem um conjunto de fornecedores que atuam diretamente sobre ela - fornecedores de primeira camada - first layer suppliers -, outro conjunto de fornecedores desses fornecedores fornecedores de segunda camada - second layer suppliers - e assim por diante. 
Da mesma forma, a empresa focal possui um conjunto de clientes com os quais se relaciona de forma direta - clientes de primeira camada - (first layer distribuidores) e outro com os quais se relaciona de forma indireta - clientes de segunda camada (second layer - varejista e/ou cliente final). A representação ainda indica o sentido básico dos relacionamentos que a empresa foco pode conduzir: à montante - upstream - no sentido de seus fornecedores, e à jusante downstream - no sentido do cliente final (LAMBERT et al., 1998).

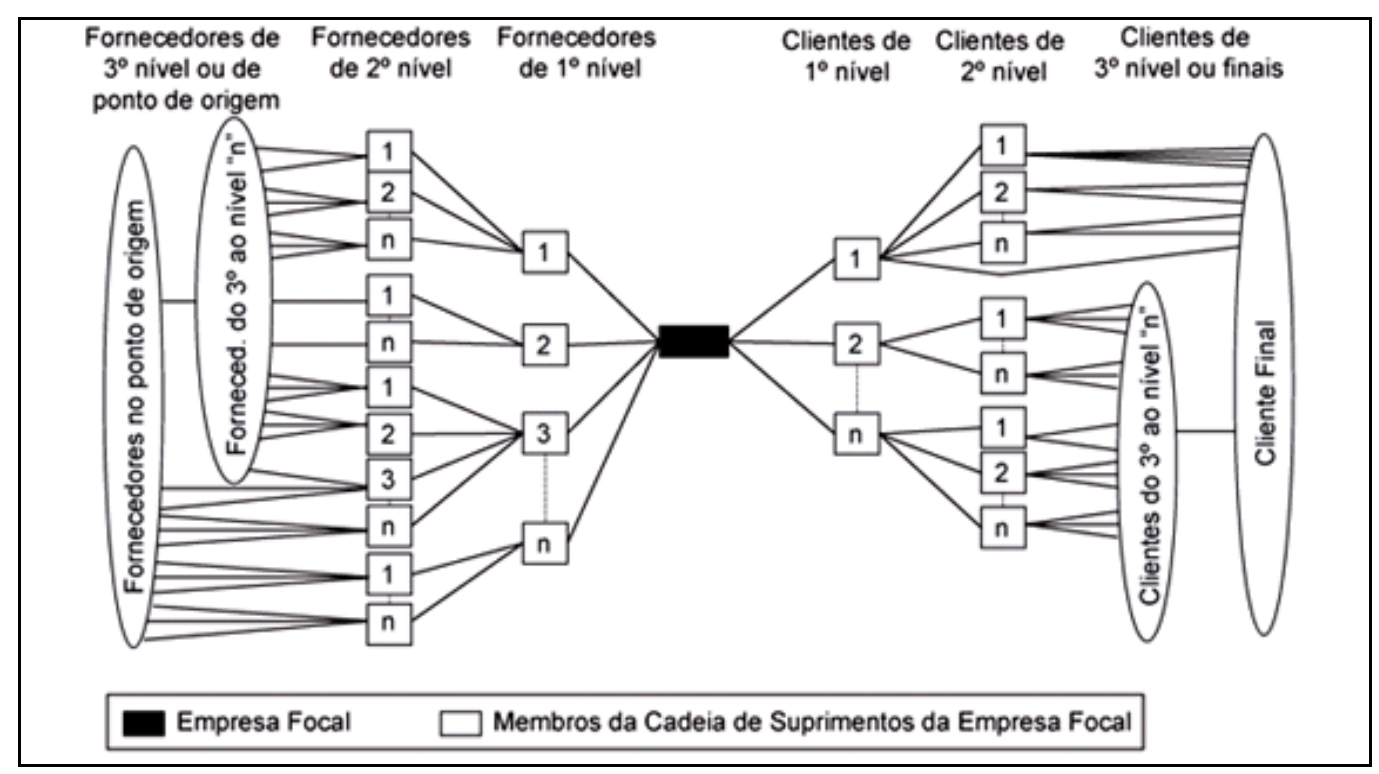

Figura 2: A estrutura da cadeia de suprimentos.

Fonte: Adaptado de Lambert \& Cooper (2000)

Embora o termo cadeia transmita uma ideia de linearidade, é de reconhecimento universal que o termo cadeia de suprimentos não é uma cadeia linear de negócios com relacionamentos um a um, mas uma rede de trabalho com múltiplos negócios e relacionamentos (PIRES, 2004).

Como na realidade é uma rede complexa de instalações e organizações com objetivos distintos e conflitantes, alguns autores sugerem o uso do termo rede de suprimentos - supply networks - ao invés de cadeia de suprimentos (SIMCHILEVI et al.,2003). Além do mais, uma cadeia de suprimentos não é estática, e sim um sistema dinâmico que evolui ao longo do tempo.

Sua visualização depende do foco que se deseja ter da mesma: se no ciclo completo da atividade logística (end-to-end) ou apenas em partes. O escopo de 
uma cadeia de suprimentos é definido pelo número de empresas, atividades e funções envolvidas (COOPER et al., 1997).

O conceito de gerenciamento da Cadeia de Suprimentos surgiu para integrar eficientemente todas as instalações que impactam os custos e desempenham um papel na fabricação de um produto de acordo com as exigências do cliente. Assim sendo, a mercadoria deve ser produzida e distribuída na quantidade certa, para a localização certa e no tempo certo, visando minimizar os custos globais do sistema e, ao mesmo tempo, atingir o nível de serviço desejado, sendo eficiente e também eficaz. (SIMCHI-LEVI et al.,2003).

Desta forma, a cadeia de suprimentos surge para integrar os processos e funções não só dentro das organizações, mas também entre organizações. Para atingir os objetivos deste novo conceito, novos processos e funções foram agregados às funções e processos logísticos, passando a logística a ser um subcomponente do SCM.

Apesar de um aparente entendimento, tanto o termo Cadeia de Suprimentos quanto o escopo do Gerenciamento da Cadeia de Suprimentos ainda são confusos para a maior parte das pessoas, o que pode levar a dificultar a implementação prática dos processos e funções de sua abrangência. Do mesmo modo, Larson \& Halldorsson (2004) revelaram que logística e SCM continuam a ser vistos ou como sinônimos para as mesmas atividades, sendo uma, subconjunto da outra, ou como duas coisas distintas, mas como disciplinas que se sobrepõem.

As atividades da logística incluem tipicamente a gerência inbound e outbound do transporte, gerência da frota, armazenamento e manipulação de materiais, preenchimento do pedido, projeto de rede da logística, gerência de estoque, planejamento da demanda e do fornecimento, e gerência de fornecedores de serviços terceirizados da logística.

Em níveis variados, a função da logística inclui também a busca e a obtenção de matérias-primas, o planejamento e programação da produção, embalagem e montagem, e o serviço ao cliente, além de estar envolvida em todos os níveis do planejamento e da execução - estratégico, tático e operacional. A gerência da logística é uma função integradora, que coordena e otimiza todas as atividades, assim como integra atividades da logística com outras funções da empresa como marketing, vendas, produção, finanças, e tecnologia de informação. 
Já o SCM, segundo o CSCMP (2011), abrange o planejamento e a gerência de todas as atividades envolvidas na busca e obtenção de matérias-primas, nas trocas de produtos/serviços e informações, em todas as atividades da logística, na coordenação e colaboração com membros do canal (que podem ser fornecedores, intermediários, terceiros e clientes).

Essencialmente, o SCM integra a gerência de demanda e do fornecimento dentro e através das empresas que compõem o canal de suprimentos. O SCM é uma ferramenta de integração com responsabilidade primária de ligar funções e processos principais do negócio, dentro e através das companhias, em um modelo coeso e de alta performance. Inclui todas as atividades da gerência da logística ditas acima, assim como operações de produção, e dirige a coordenação dos processos e das atividades com e através do marketing, das vendas, do projeto de produto, das finanças e da tecnologia de informação (CSCMP, 2011).

\subsection{1}

\section{Estrutura conceitual de um SCM}

SCM na realidade representa um novo modo de se gerenciar os negócios e relacionamentos com os outros membros da cadeia de suprimentos. O modelo de Lambert \& Cooper (2000), desenvolvido inicialmente pelo GSCF (Global Supply Chain Forum,) em 1994, é o evidenciado neste trabalho por este melhor evidenciar a cadeia de suprimentos da empresa focal para o objetivo pretendido neste trabalho, em detrimento de modelos trazidos por outros autores.

Vale lembrar que todas as empresas possuem uma cadeia de suprimentos, com a qual interagem, desde o fornecedor de matéria-prima ao consumidor final, assim como toda empresa se insere em uma ou em várias cadeias. Todos os membros da cadeia necessitam ser controlados, com uma intensidade que depende de diversos fatores, especialmente a complexidade do produto, o número de fornecedores disponíveis, e a disponibilidade de matérias-primas. As dimensões da Cadeia de Suprimentos a serem consideradas em cada nível dependem do comprimento da cadeia, do número dos fornecedores e dos clientes em cada um dos referidos níveis. 
É importante ainda ressaltar que é raro que uma empresa participe somente de uma única Cadeia de Suprimentos. Para a maioria de fabricantes, a cadeia de suprimentos parece menos uma cadeia ou canal e mais uma árvore, onde os galhos e as raízes são os clientes e fornecedores. Além disso, existem diferentes tipos de relacionamentos na Cadeia de Suprimentos, alguns mais próximos que outros.

A figura 3 ilustra o framework de Gerenciamento de uma Cadeia de Suprimentos conforme proposto por Lambert \& Cooper (2000). Essa figura mostra três núcleos da estrutura de gerenciamento que serão discutidos a seguir.

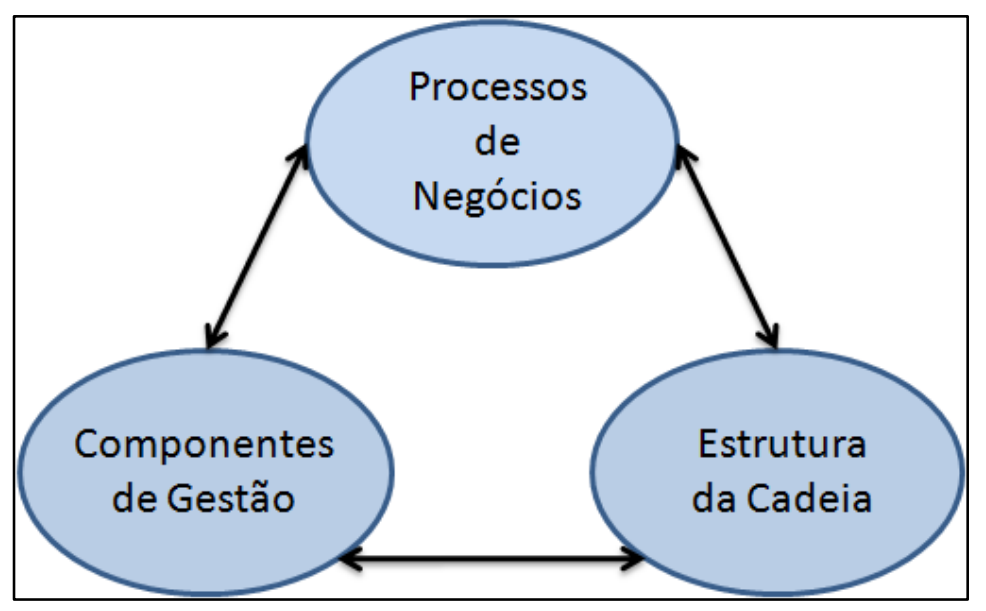

Figura 3 - Framework do gerenciamento da cadeia de suprimentos. Fonte: Lambert \& Cooper, 2000

É importante ter um conhecimento e uma compreensão explícitos deste Gerenciamento da Cadeia de Suprimentos, e o primeiro núcleo a ser abordado estrutura da cadeia - apresenta três aspectos primários, conforme sugerido pelos autores, a saber: (1) os membros da cadeia; (2) as dimensões estruturais e, (3) os tipos de links.

(1) Os membros da cadeia de suprimentos - $O$ primeiro passo é identificar quem são os membros que farão parte da visualização da cadeia de suprimentos, visto que colocar todos os membros pode se tornar muito complexo. Uma base sugerida pelos referidos autores para a escolha dos membros é a identificação entre: (a) membros primários que são as empresas ou negócios estratégicos que executam atividades que agregam valor na produção de um produto/serviço específico para 
um dado cliente ou mercado, e (b) os membros de apoio - empresas ou negócios estratégicos que simplesmente proveem recursos, conhecimento, utilidade ou ativos para os membros primários da cadeia de suprimentos - similar à cadeia de valor definida por Porter (1981) para a identificação das atividades. Definindo os membros primários e de apoio, é possível delimitar o ponto de origem e o ponto de consumo. No presente trabalho são classificados como membros primários os fornecedores diretos da empresa focal, e esta pesquisa se restringirá a estes membros.

(2) As dimensões estruturais da rede - três dimensões estruturais são essenciais para descrever, analisar e gerenciar uma cadeia de suprimentos: (a) estrutura horizontal - refere-se ao número de camadas na cadeia; (b) estrutura vertical - refere-se ao número de fornecedores/clientes representados em cada camada, e (c) a posição horizontal - onde a empresa se localiza dentro da cadeia de suprimentos. Este trabalho analisa somente uma camada da estrutura horizontal à montante e à jusante. A cadeia a ser descrita possui em sua estrutura vertical muitos fornecedores à montante, e à jusante todas as lojas (pontos de venda) da empresa focal espalhadas pela cidade do Rio de Janeiro.

(3) Os tipos diferentes dos links de processos - os níveis de integração e gerenciamento variam de link para link, uma vez que os direcionadores para integração são situacionais e diferentes. Alguns links são mais críticos que outros, e eles podem não estar necessariamente nos membros imediatamente adjacentes. Como consequência, a tarefa de alocar recursos escassos entre os diferentes links na cadeia de suprimentos se torna crucial. Quatro tipos diferentes de links foram identificados entre os membros de uma cadeia de suprimentos: (a) os gerenciados - são os links que são importantes para a empresa, e devem ser integrados e gerenciados; (b) os monitorados - não são tão críticos para a empresa, contudo tão frequente quanto for necessário, a empresa 
deve simplesmente monitorar ou auditar como o link está sendo gerenciado e integrado apropriadamente entre os outros membros; (c) os não gerenciados - são os links em que a empresa focal não está ativamente envolvida, nem são críticos bastante para usarem recursos de monitoramento, isto é, deixa com que os outros membros da cadeia gerenciem o link apropriadamente, ou devido a recursos limitados, deixa por conta deles próprios; $e(d)$ os não-membros - são os links entre membros da cadeia de suprimentos da empresa focal e não membros da cadeia de suprimentos, isto é, fazem parte de outra cadeia de suprimentos, mas que podem afetar a performance da empresa focal e de sua cadeia de suprimentos. Neste trabalho dar-se-á atenção somente aos links gerenciados.

\section{1 .2}

\section{Processos de negócios na cadeia de suprimentos}

Segundo Lambert (2004), um SCM bem-sucedido requer uma mudança de gerenciamento das funções individuais para o gerenciamento de um conjunto de processos integrados, que são usados para estruturar as atividades entre os membros de uma cadeia de suprimentos. Para o autor, é necessária uma reengenharia ampla na forma de gerenciamento da cadeia de suprimentos através da implantação, em conjunto, de processos de negócios integrados nos membros da cadeia de suprimentos. O valor de se ter processos de negócios padronizados em uma cadeia de suprimentos é válido para que os gerentes das organizações possam usar uma linguagem comum e possam associar os processos de suas companhias com os outros membros da cadeia de suprimentos.

A motivação para implementar processos de negócios internamente e com outros membros da cadeia de suprimentos pode ser para fazer com que as transações se tornem mais eficientes e eficazes, indo de encontro com as expectativas dos clientes, através da padronização das transações e na transferência de informação, ou para estruturar os relacionamentos na cadeia de suprimentos buscando comprometimentos mútuos de longo prazo (LAMBERT, 2006). 
Lambert (2004) identifica oito processos essenciais do SCM que devem ser implementados nas organizações, sendo que todos são multidisciplinares e transorganizacionais por natureza, a saber: (1) CRM (Consumer relationship management - gerenciamento do relacionamento do cliente); (2) Gerenciamento do serviço ao cliente; (3) Gerenciamento da demanda; (4) Preenchimento do pedido; (5) Gerenciamento do fluxo de produção; (6) SRM (Supplier relationship management - gerenciamento do relacionamento com fornecedores); (7) Desenvolvimento do produto e comercialização; (8) Gerenciamento reverso.

Em consonância com a proposta deste trabalho e aos processos que são relevantes para o seu desenvolvimento, somente alguns dos processos de negócios propostos por Lambert \& Cooper (2000) são detalhados, a saber: Gerenciamento da Demanda; Preenchimento do Pedido; e, Supplier Relationship Management.

\section{(a) Gerenciamento da demanda}

Gerenciamento da demanda é o processo que busca o equilíbrio entre as necessidades do cliente com a capacidade da Cadeia de Suprimentos. Parte deste gerenciamento envolve estar atento à determinação do que e quando os clientes irão comprar.

Um bom sistema de gerenciamento de demanda utiliza pontos de venda e dados de clientes-chave para reduzir a incerteza e prover fluxo eficiente através da Cadeia de Suprimentos. É importante notar que este processo não é limitado à previsão da demanda. Também coordena efetivamente as necessidades de marketing e os planos de produção em bases que abranjam toda a empresa.

Tal gerenciamento é importante diante do tema abordado no presente estudo, visto que o gerenciamento da demanda deve ocorrer nos pontos de venda finais - lojas do varejo -, identificando produtos-chave para as referidas lojas e seus consumidores, assim como o gerenciamento da demanda das $n$ lojas deve ser feito com acuracidade pelo Centro de Distribuição, a fim de que nenhum ponto de venda final deixe de ser abastecido em suas necessidades. É o planejamento e o gerenciamento da demanda acontecendo nas diversas camadas da cadeia de suprimento. 


\section{(b) Preenchimento do pedido}

Esse processo envolve não somente o preenchimento do pedido. Engloba todas as atividades necessárias para definir as necessidades do cliente, de projetar uma cadeia, e de capacitar uma empresa a encontrar as necessidades do cliente, enquanto minimiza o custo total entregue.

Um trabalho de parceria com os fornecedores é fundamental neste processo para que o CD consiga suprir todas as lojas do varejo ao menor tempo e custo possíveis.

\section{(c) SRM (Supplier relationship management)}

Este processo provê uma estrutura para desenvolvimento e manutenção de relacionamentos com fornecedores. É um espelho do CRM e envolve desenvolver relacionamentos mais próximos com um pequeno grupo de fornecedores, baseados nos valores que eles trazem à empresa no decorrer do tempo, que seriam os fornecedores-chave.

A informatização do processo de compras pela utilização de ferramentas de comunicações mais rápidas - via EDI (Eletronic Data Interchange) - também provê um modo de se reduzir tempo e custo despendidos nas transações de compras, possibilitando um enfoque maior no gerenciamento de fornecedores.

Um bom relacionamento com os fornecedores de primeira camada é condição fundamental para que as evidências em redução de tempo e custo de entrega sejam efetivas na cadeia que o presente trabalho está focando. $\mathrm{O}$ gerenciamento deste relacionamento é de extrema relevância para que resultados significativos sejam uma realidade.

A visualização dos processos de negócios na cadeia de suprimentos pode ser observada na Figura 4. 


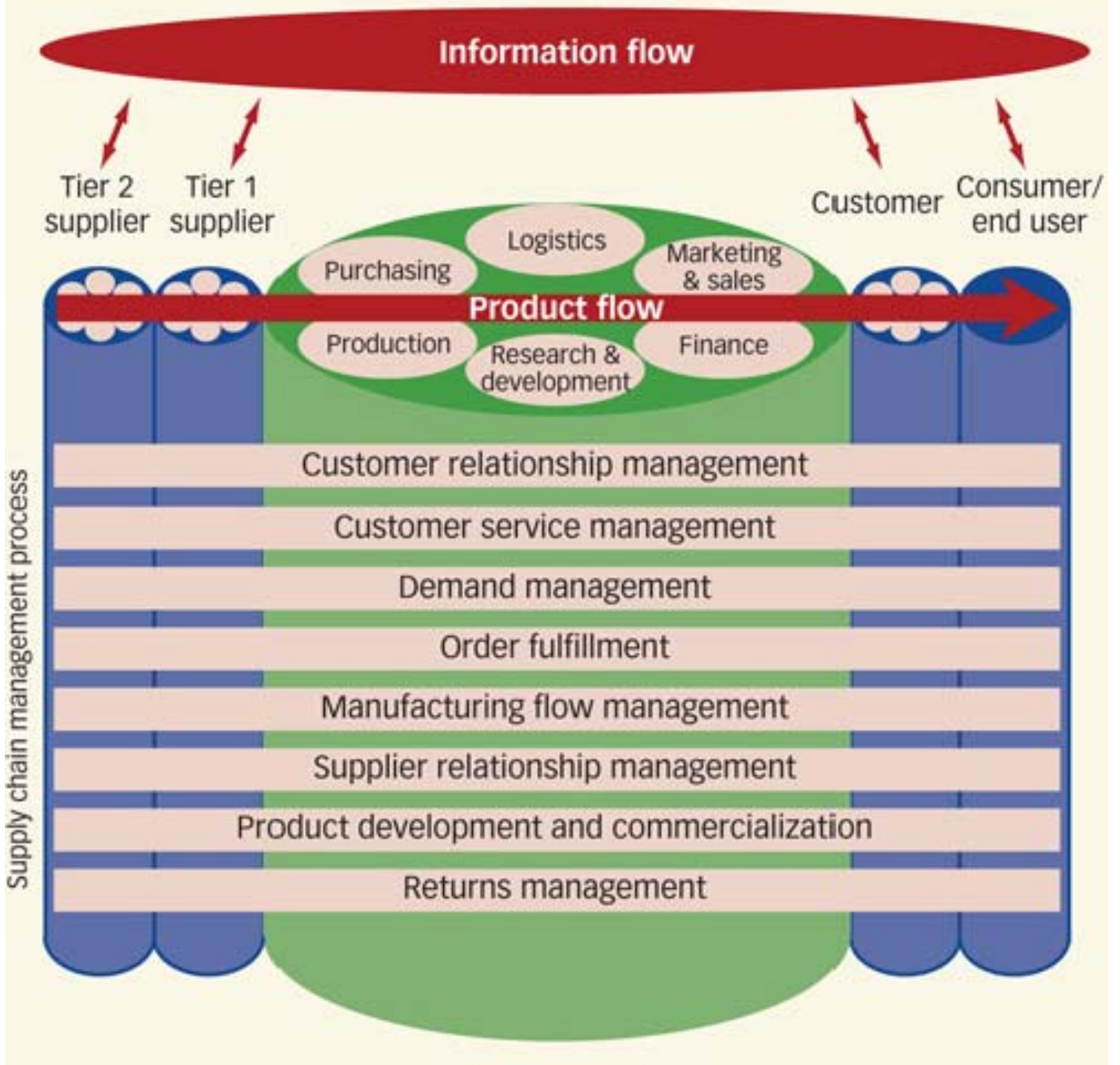

Figura 4 - Gerenciamento da cadeia de suprimentos: integrando e gerenciando processos de negócios na cadeia de suprimentos.

Fonte: LAMBERT, et al.1998.

\subsection{3}

\section{Os componentes gerenciais do SCM}

Com base em revisão de literatura e pesquisas com executivos desenvolvidas pelos autores Lambert \& Cooper (2000), foram identificados nove componentes gerenciais que devem receber especial atenção por parte das empresas que enfrentam o desafio do SCM. Tais componentes foram divididos em dois grupos: componentes técnicos e físicos, mais fáceis de serem mensurados; e componentes gerenciais e comportamentais mais intangíveis e, portanto, mais difíceis de serem mensurados e controlados. 
Dentre os componentes técnicos e físicos, os autores citam:

- planejamento e controle das operações - chave para a movimentação da organização ou da cadeia de suprimentos em uma dada direção. Quanto mais integrado for o planejamento, maiores os benefícios percebidos da integração. $\mathrm{O}$ controle pode ser implementado através da definição de indicadores de performance globais;

- estrutura de trabalho e de atividades - indica como a empresa realiza suas tarefas e atividades. O nível de integração das atividades numa cadeia é um importante fator de sucesso na integração da cadeia;

- estrutura organizacional - refere-se à organização da empresa e à organização da cadeia. A utilização de equipes multidisciplinares ou de equipes compostas por pessoas de várias empresas da cadeia é um fator de estímulo à integração da cadeia;

- estrutura do fluxo do produto - refere-se à estrutura da rede de obtenção, produção e distribuição ao longo da cadeia;

- estrutura do fluxo de comunicação e informação - o tipo de informação, que é compartilhada, e a frequência de compartilhamento são fatores que têm forte influência na integração da cadeia.

Dentre os componentes gerenciais e comportamentais, os autores citam:

- métodos de gerenciamento - que incluem a filosofia corporativa e as técnicas de gerenciamento utilizadas. Estruturas diferentes são difíceis de integrar;

- estrutura de poder e liderança - afeta a forma da cadeia de suprimentos. Tanto a falta de poder, como a concentração de poder, pode afetar o nível de comprometimento dos membros da cadeia e consequentemente o processo de integração da cadeia; 
- estrutura de riscos e recompensas - a divisão dos riscos e recompensas pode afetar o comprometimento dos membros da cadeia;

- cultura e atitudes - diferentes culturas e atitudes organizacionais dificultam a integração.

Apesar da importância dos elementos técnicos associados à implementação do SCM, Lambert \& Cooper (2000) acreditam que as empresas que tiverem como foco de gerenciamento somente os componentes relacionados aos aspectos físicos e técnicos do processo enfrentarão dificuldades, uma vez que os componentes gerenciais e comportamentais definem o comportamento organizacional, influenciando a implementação dos primeiros.

Lambert et al. (1998) enfatizam que a Gestão de Cadeia de Suprimentos e a Logística não são sinônimos.

Muitos pesquisadores e acadêmicos, tentando relacionar Logística e Gestão da Cadeia de Suprimentos, determinaram 4 (quatro) perspectivas: a Re-rotulista, onde Gestão da Cadeia de Suprimentos é o que antes era a Logística; a Tradicionalista, que encaixa a Gestão da Cadeia de Suprimentos dentro da logística; Unionistas, que enquadram a Logística dentro da Gestão da Cadeia de Suprimentos; e os Inter-seccionistas, que consideram a Gestão da Cadeia de Suprimentos como a união da logística, marketing, operações e compras. A perspectiva Unionista é a adotada pela maioria das escolas de administração, sendo Lambert e Cooper integrantes desta (COSTA et al., 2005).

Como este trabalho discorre sobre as ações logísticas ao longo da cadeia do varejo, demonstrando ganhos advindos deste gerenciamento, o conceito de logística é abordado a seguir.

\section{2}

\section{Logística}

Produzir, transportar, armazenar, distribuir. Estes termos, se pensados em conjunto, retratam uma atividade há muito colocada em prática pelas sociedades, 
mas que ganhou maior sentido e organização somente a partir do século XX: a Logística.

A logística é um verdadeiro paradoxo. É, ao mesmo tempo, uma das atividades econômicas mais antigas e um dos conceitos gerenciais mais modernos. Desde que o homem abandonou a economia extrativista e deu início às atividades produtivas organizadas, com produção especializada e troca de excedentes com outros produtores, surgiram três das mais importantes funções logísticas, ou seja: estoque, armazenagem e transporte.

Foi a partir década de 80 que o desenvolvimento da Logística tornou-se revolucionário em virtude de fatores, como explosão da tecnologia da informação, alterações estruturais surgidas nos negócios e na economia dos países emergentes, formação de blocos econômicos e o fenômeno da globalização.

De acordo com o Council of Supply Chain Management Professionals, CSCMP (2011), a definição de logística, em tradução livre, passa a ser a seguinte:

"Logística é a parte do processo da Cadeia de Suprimento que planeja, implementa e controla tanto o fluxo normal e reverso, efetivamente $e$ eficientemente, quanto o armazenamento de materiais, serviços, além de relatar a informação desde o ponto de origem até o ponto de consumo, com o propósito de atender os requisitos dos clientes. Seu gerenciamento é responsável pela coordenação e otimização de todas as atividades logísticas, assim como a integração dessas atividades com outras funções, incluindo marketing, vendas, produção, finanças e tecnologia da informação".

Em termos operacionais, segundo Ballou (2001), a Logística envolve todas as operações relacionadas com planejamento e controle de produção, movimentação de materiais, embalagem, armazenagem e expedição, distribuição física, transporte e sistemas de comunicação que, realizadas de modo sincronizado, podem fazer com que as empresas agreguem valor aos serviços oferecidos aos clientes, oportunizando um diferencial competitivo perante a concorrência. 
Para definir a importância da logística, Ballou (2001) salienta que ela é responsável por oferecer mercadorias ou serviços esperados pelos clientes, nos locais apropriados em relação as suas necessidades, nos prazos acertados ou esperados e nas melhores condições físicas possíveis, a fimm de atender às necessidades dos clientes, proporcionando o máximo de retorno financeiro para a empresa.

Bowersox (1996) entende que o objetivo central da logística é o de atingir um nível de serviço ao cliente pelo menor custo total possível, buscando oferecer capacidades logísticas alternativas com ênfase na flexibilidade, na agilidade, no controle operacional e no compromisso de atingir um nível de desempenho que implique um serviço perfeito.

Ballou (2001) afirma que o planejamento logístico tem por objetivo desenvolver estratégias que possam resolver os problemas de quatro áreas de destaque nas empresas que são: (i) o nível de serviços oferecido aos clientes; (ii) localização das instalações de centros de distribuição; (iii) decisões de níveis de estoque; e (iv) decisões de transportes que devem ser utilizados no desenvolvimento de todo o processo.

É o conceito de logística integrada que vários autores consideram como fundamental para o gerenciamento da Cadeia de Suprimentos. A Figura 5 evidencia o framework de logística integrada. 


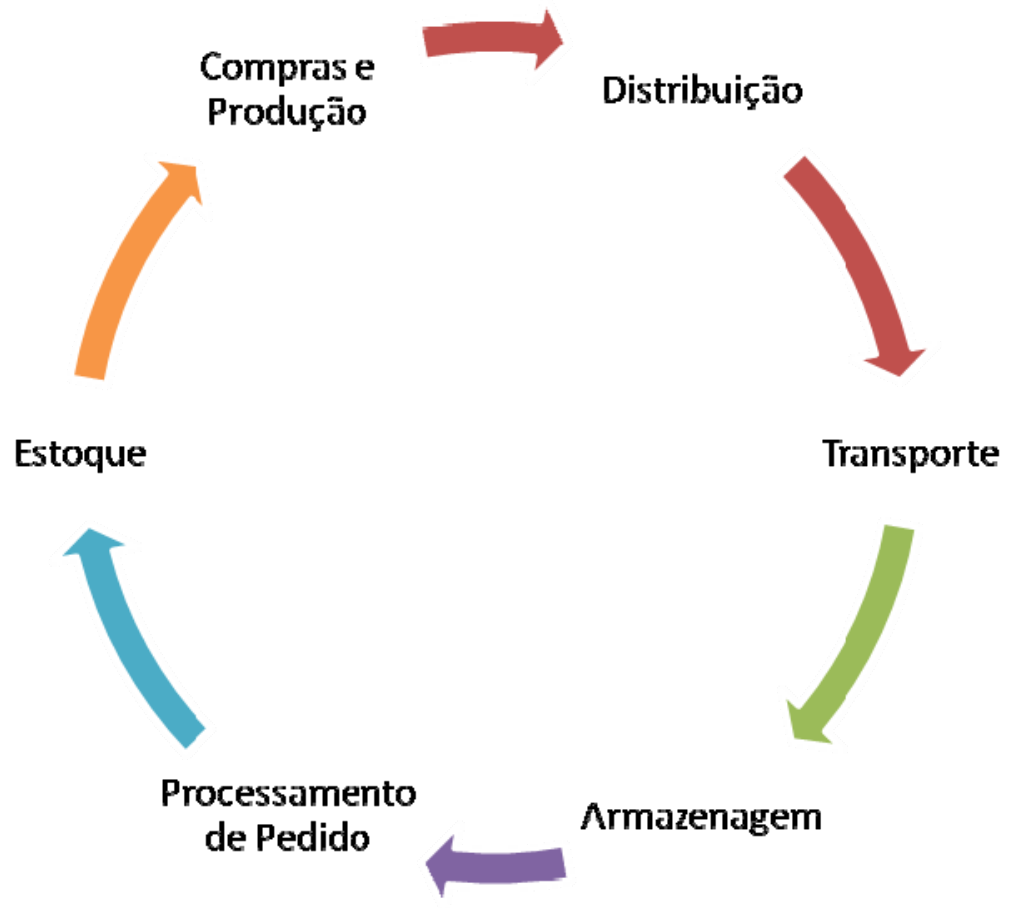

Figura 5: Framework de logística integrada. Fonte: Wanke et.al., (2011).

O conceito de logística integrada parte do princípio de que o sistema logístico deve ser entendido como um instrumento operacional de marketing. Um dos modelos mais utilizados para o estabelecimento de uma estratégia de marketing é o do marketing mix (KOTLER, 1998), popularmente denominado de modelo dos 4 Ps. Segundo este modelo, a estratégia de marketing deve ser estabelecida a partir de políticas de produto, preço, promoção e praça, ou seja, canais de distribuição.

Ao definir uma política de canais de distribuição, cria-se para a organização logística uma missão, pois cabe à logística o papel de operacionalizar esta política. Portanto, a estrutura de um sistema logístico deve ser projetada a partir do estabelecimento de sua missão, que resulta da formalização dos tipos e níveis de serviços a serem oferecidos aos diferentes canais e segmentos de clientes. A montagem de um sistema logístico, por outro lado, compreende cinco componentes básicos: transporte; armazenagem; estoque; processamento de pedidos/ informações, e produção/compras.

De acordo com este conceito, o papel da organização logística é atender os níveis de serviços estabelecidos pela estratégia de marketing ao menor custo total de seus componentes, ou seja, ao menor somatório dos custos dos componentes. 
Importante chamar atenção para os trade-offs existentes entre os componentes do sistema logístico. A existência destes trade-offs exige uma coordenação / integração entre os diversos componentes.

Desta forma, entende-se que na logística integrada os custos dos cinco componentes básicos devem ser gerenciados de perto e isto leva à necessidade de discorrer, neste trabalho, sobre o conceito de custos logísticos apresentados pela literatura, pois é pautado na redução de tais custos que o presente trabalho se desenvolve.

\subsection{1}

\section{Custos Logísticos}

Diante da evolução das atividades logísticas, as organizações enfrentam dois problemas básicos: o primeiro referente à magnitude dos custos logísticos e o segundo, à maneira que estes custos são alocados. O bom gerenciamento de tais custos pode favorecer o aumento da eficiência nos processos internos e externos à organização, como também melhorar a relação com seus prestadores de serviço e clientes, muitas vezes vítimas de um subsídio cruzado de custos (WANKE, 2011).

Embora não existam levantamentos específicos, estima-se que no Brasil os gastos com as atividades logísticas correspondem a cerca de $12 \%$ do PIB, e que, na média, o transporte corresponde a $60 \%$ dos custos logísticos. (ILOS 2012)

No âmbito das empresas a Logística tem uma importância econômica significativa. Na Tabela 1 é apresentada a composição dos custos e margem típicos de uma empresa industrial representativa.

Tabela 1 - Composição de custos e margem de uma empresa industrial típica.

\begin{tabular}{|c|c|}
\hline Margem & $8 \%$ \\
\hline Custos logísticos & $19 \%$ \\
\hline Custos de Marketing & $20 \%$ \\
\hline Custos de Produção & $53 \%$ \\
\hline
\end{tabular}

Fonte: Wanke (2011) 
Verifica-se pela Tabela 1 que os custos logísticos representam cerca de 19\% da receita total, e, o que é mais importante, o dobro da margem líquida de cerca de $8 \%$. Portanto, qualquer redução nos custos logísticos pode ter um forte impacto nas margens e, consequentemente, no lucro de uma companhia.

A Figura 6 evidencia os fatores que compõem o custo logístico de uma organização, adotando o modelo do Instituto de Logística e Supply Chain.

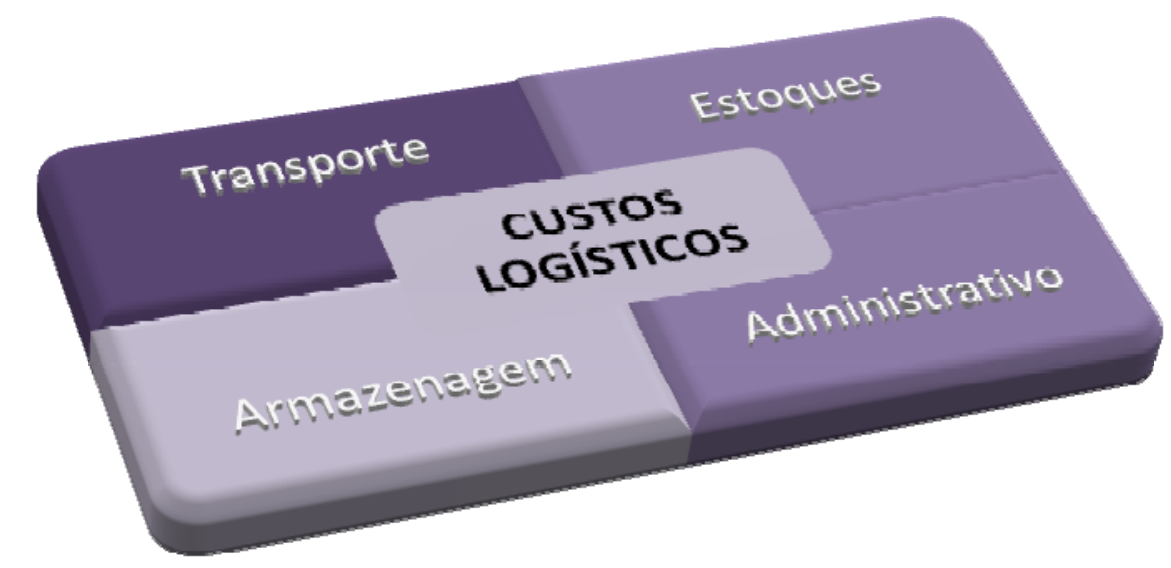

Figura 6: Fatores que compõem os Custos logísticos. Fonte: ILOS (2012)

\section{a) Transporte}

O transporte, na maioria das vezes, representa a maior parcela do custo logístico de uma empresa. Devido a isto, a preocupação com este fator é relevante e deve ser analisada continuamente com vistas à redução.

É importante também destacar que o transporte tem papel fundamental na satisfação do cliente final devido ao mesmo estar ligado à dimensão tempo. Segundo Wanke et al. (2011), do ponto de vista de custos, os transportes representam, em média, cerca de $60 \%$ das despesas logísticas, o que, em alguns casos, pode significar duas ou três vezes o lucro de uma companhia, como é o caso, por exemplo, do setor de distribuição de combustíveis.

Desde os primórdios, o transporte tem sido utilizado para disponibilizar produtos onde existe demanda potencial, dentro do prazo adequado às necessidades do comprador. Mesmo com o avanço de tecnologias que permitem a troca de informações em tempo real, o transporte continua sendo fundamental 
para que seja atingido o objetivo logístico, que é o produto certo, na quantidade certa, na hora certa, no lugar certo, ao menor custo possível. Ainda segundo o autor, dentre os principais trade-offs que afetam a função transporte, destacam-se os relacionados ao estoque e ao serviço ao cliente.

Em uma visão não integrada, o gestor de estoques possui somente o objetivo de minimizar custos com estoque, sem analisar todos os custos logísticos. Esse tipo de procedimento impacta de forma negativa nas outras funções logísticas, como, por exemplo, a produção, que passa a necessitar de maior flexibilidade, pois terá que lidar com lotes menores e mais frequentes, ocasionando um custo maior. Além disso, uma gestão de transporte caracterizada pelo transporte mais fracionado acarreta aumento do custo unitário do transporte.

Com relação ao trade-off de serviço ao cliente, deve-se ao fato das principais exigências do mercado geralmente estarem ligadas à pontualidade do serviço, à capacidade de prover um serviço porta-a-porta, à flexibilidade no que diz respeito ao manuseio de uma grande variedade de produtos, ao gerenciamento dos riscos associados a roubos, danos e avarias e à capacidade de o transportador oferecer mais que um serviço básico de transporte.

De acordo com Wanke et al. (2011), estudos realizados em empresas brasileiras constataram um padrão elevado de ineficiência no transporte, sobretudo nas atividades de carregamento e descarregamento, em que os tempos de espera geralmente ultrapassam seis horas. Por outro lado, um grande número de transportadoras mensura seus custos de frete com base em uma metodologia que aloca os custos fixos a cada rota em proporção à quilometragem percorrida. Esses métodos de custeio criam distorções no resultado; especificamente, rotas longas absorvem um custo maior do que deveriam absorver e as rotas curtas, um custo menor do que deveriam absorver, isto é, há um subsídio cruzado em que as rotas longas subsidiam as rotas curtas. A distorção existe porque o custo de cada rota depende, de forma significativa, dos custos de atividades de carregamento e descarregamento, que são em função do tempo que tais atividades consomem e não da quilometragem percorrida.

As consequências dessas distorções podem ser desastrosas à medida que inviabilizam um processo de negociação de preços baseado no grau de eficiência do uso dos recursos e contribuem para manutenção de práticas tradicionais de 
negociações de preço, baseadas na quilometragem e, por ocasião de reajustes, nas variações nos preços dos insumos. O subsídio cruzado entre rotas implica preços baixos para rotas curtas e preços altos para as rotas longas. Como rotas curtas custam mais que o sistema tradicional de custeio indica, pois alocam pela quilometragem, elas serão pouco lucrativas, ocorrendo com as rotas longas exatamente o contrário. Essa situação faz com que a gerência de muitas transportadoras não utilize sistemas de custeio como ferramenta de apoio à tomada de decisão, tornando-os cada vez mais desacreditados.

A penetração cada vez mais rápida em novos mercados ou a consolidação do market share já existente passa pela adoção de novas estratégias para gestão da distribuição na Cadeia de Suprimentos. É dentro desse contexto que deve ser entendido o estabelecimento de parcerias - alianças logísticas - de uma empresa com seus prestadores de serviço de transporte.

Segundo Bowersox (1996), o relacionamento tradicional existente entre uma empresa e suas transportadoras é antagônico e adversário, isto é, um jogo do tipo "perde-ganha", em que cada uma das partes está buscando sempre aumentar sua margem no negócio em detrimento da outra. Em geral as empresas contratantes barganham tabelas de preço de frete em função de seu poder econômico. Consequentemente, o compartilhamento de informações e o planejamento de diversas atividades logísticas, como, por exemplo, programação de entregas, carregamento no distribuidor e descarregamento nos clientes finais, é mínimo ou quase inexistente.

Para que haja a implementação de parcerias logísticas efetivas entre uma empresa e seus transportadores é necessário o estabelecimento de um ambiente de confiança mútua entre as partes. Não é tarefa fácil, visto que inúmeras barreiras culturais dentro e fora da organização devem ser vencidas. La Londe \& Cooper (1989) propõem uma filosofia de gestão logística capaz de enxergar os principais ganhos decorrentes de uma nova relação empresa versus transportador, ou seja, a criação de uma interface coordenada, eficiente e previsível com seus clientes. Para as transportadoras, por sua vez, a contrapartida encontra-se numa maior previsibilidade quanto ao nível de capacidade adequado - dimensionamento de frota - quanto a seu horizonte de investimento e quanto à oportunidade de aprimorar suas práticas operacionais com seus demais parceiros (diferenciação). 
Gardner \& Cooper (1994) ressaltam que o estabelecimento de relações de parceria e, consequentemente, da nova filosofia de gestão proposta por La Londe \& Cooper (1989), é facilitado quando se limita o número de parceiros transportadores, possibilitando maior controle sobre o serviço fornecido, ao ser garantido em contrapartida um maior e mais seguro volume de frete no longo prazo.

Em um processo de instalação de um $\mathrm{CD}$, os custos com transporte partindo do fornecedor têm uma significativa redução devido à mudança de uma entrega descentralizada e fragmentada, para uma entrega centralizada, diminuindo, entre outras coisas, o tempo de entrega nos pontos finais de venda. Neta situação, é primordial que ocorram as parcerias logísticas, objetivando o "ganha-ganha" para as partes.

\section{b) Custo de Estoque e Armazenagem}

Na mesma proporção em que se realiza uma análise dos custos de comprar e estocar, os responsáveis pela área de materiais identificam primeiro os custos que serão afetados por sua decisão, antes da realização do pedido de materiais.

Os custos que incidem sobre o estoque são:

- Custo de Aquisição

- Custo de Armazenagem

- Custo do Pedido

- Custo da Falta de Estoque

A administração central da empresa deverá determinar ao Departamento de Controle de Estoques o programa de objetivos a serem atingidos, isto é, estabelecer certos padrões que sirvam de guia aos programadores e controladores e também de critérios para medir a performance do Departamento.

Estas políticas são diretrizes que, de maneira geral, (a) estabelecem metas da empresa quanto a tempo de entrega dos produtos ao cliente; (b) definem o número de depósitos e/ou de almoxarifados e da lista de materiais a serem estocados neles; (c) até que níveis deverão flutuar os estoques para atender uma alta ou baixa das vendas ou uma alteração de consumo; (d) até que ponto será permitida a especulação com estoques, fazendo compra antecipada com preços 
mais baixos ou comprando uma quantidade maior para obter descontos; e (e) definem a rotatividade dos estoques.

As definições das políticas são muito importantes ao bom funcionamento da administração de estoque. Os itens $\boldsymbol{c}$ e $\boldsymbol{e}$ citados são os que merecem maior atenção, porque é exatamente neles que também vai ser medido o capital investido em estoques.

Tome-se o exemplo adotado por Wanke et al. (2011), em que um Centro de Distribuição - CD - possua demanda anual média de 300 unidades para um determinado produto e considere duas políticas de ressuprimento alternativas, conforme Figura 7. Na política 1 são enviados 6 carregamentos com 50 unidades ao longo do ano. Na Política 2 as 300 unidades são enviadas de uma só vez.
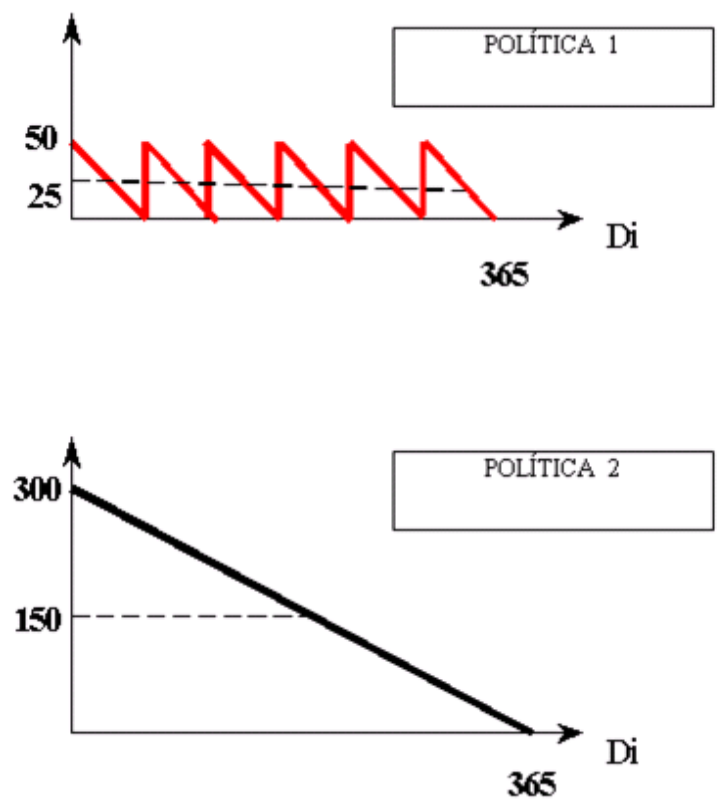

Figura 7: Políticas de abastecimento. Fonte: WANKE et al. (2011)

Na primeira política a empresa incorre num menor custo de oportunidade de manter estoques, por operar com um nível de estoque médio de apenas 25 unidades. Os gastos com transporte, entretanto, são maiores não apenas devido a um maior número de viagens, mas também devido aos carregamentos fracionados.

Por outro lado, na Política 2, os custos de oportunidade de manter estoques são maiores (nível de estoque médio de 150 unidades). Em contrapartida, os gastos com transporte são menores por ocorrer apenas uma viagem, e o custo 
unitário do frete pode ser menor, em virtude de possíveis economias de escala decorrentes do envio de um único carregamento consolidado.

Vale ressaltar que a política ideal sempre será determinada com base no valor mínimo da soma do custo de oportunidade de manter estoques com os gastos com transporte. Em resumo, o trade-off custo de estoque $\mathrm{x}$ custo de transporte x nível de serviço se faz presente nesta tomada de decisão logística.

No varejo, os custos de armazenagem também são bastante representativos. Não há dúvidas sobre a relevância dos custos associados ao espaço em gôndolas e a reposição de mercadorias. No entanto, esses custos usualmente não são vistos como de armazenagem. Na realidade, não importa se a empresa os considera, ou não, como de armazenagem, mas sim se a mesma metodologia de alocação pode ser utilizada com sucesso. Afinal, isto se refere à movimentação e acondicionamento de mercadorias.

Outra forte tendência do varejo é operar com depósitos de estoques centralizados e com a prática do cross-docking, tornando mais expressivos os custos de armazenagem, relativamente aos custos de estoque, que tendem a reduzir-se diante da centralização.

Voltando a atenção para a centralização dos estoques - objeto de estudo deste trabalho - alguns autores já discutiam tal assunto na década de 60. Starr \& Miller (1962) consideram estoques de reserva em $n$ depósitos e examinam a transferência de parte destes estoques para um depósito central verificando os ganhos de escala. Os autores afirmam que o mesmo nível de proteção pode ser oferecido, mas com menor volume de estoque.

Maister (1976) demonstra a lei da raiz quadrada das locações, que estabelece que o estoque total de um sistema é proporcional à raiz quadrada do número de localizações nas quais o produto é estocado. Sua demonstração supõe também o uso do lote econômico de compras. Eppen (1979) parte do the newsboy problem, ou problema do pequeno jornaleiro, com demanda normal e examina o efeito de centralizar os estoques, e chega às seguintes conclusões: o custo de manter estoques em um sistema descentralizado é superior aos custos de um sistema centralizado; a magnitude das economias depende da correlação das demandas; e se as demandas são idênticas e não correlacionadas, os custos aumentam segundo a raiz quadrada do número de pontos de demanda. Nozick \& 
Turnquist (1998) estudaram a demanda de concessionárias de automóveis, sujeitas a demandas que seguem a distribuição de Poisson, e concluíram que, ao centralizar estoques, o nível de estoque necessário evolui segundo a raiz quadrada do número de concessionárias.

\section{c) Custo Administrativo}

Qualquer atividade, seja ela industrial ou do varejo, necessita de matériasprimas, componentes, equipamentos e serviços que possam permitir a sua devida operação. No ciclo de um processo de fabricação, antes de se dar início à primeira operação, os materiais e insumos gerais devem estar disponíveis, mantendo-se com certo grau de certeza, a continuidade de seu abastecimento a fim de atender as necessidades ao longo do período.

A necessidade de se comprar adequadamente, verificando melhores prazos e preços, assim como qualidade e volume dos produtos adquiridos, é enfatizada por todos os empresários, juntamente com as necessidades de estocar em níveis adequados e de racionalizar o processo produtivo. Algo também importante refere-se a manter-se bem relacionado com o mercado fornecedor antevendo, na medida do possível, eventuais problemas que possam prejudicar a empresa no cumprimento de suas metas.

Cooper \& Lambert (1997) reforçam a importância deste processo de negócio - processamento de pedido - como fundamental para minimização do custo total entregue, através de uma parceria com os fornecedores.

Segundo Christopher (1992), os custos administrativos são os custos que ocorrem a cada vez que um pedido é emitido; são os custos fixos e variáveis referentes a esse processo. Os custos fixos são os associados aos salários do pessoal envolvido na emissão dos pedidos e não são afetados pela política existente de estoque. Os custos variáveis consistem nas fichas de pedidos e nos processos de enviar esses pedidos aos fornecedores, bem como todos os recursos necessários para tal procedimento. Portanto, o custo de pedido está diretamente determinado com base no volume das requisições ou pedidos que ocorrem no período. 
O total das despesas que compõem o custo do pedido refere-se à mão de obra - salários e encargos do setor de compras -; material utilizado para a emissão do pedido - impressos, materiais de escritório, impressora -; e custos indiretos, tais como internet, luz, água, telefone, viagens, correio, EDI, entre outros.

Para calcular o custo do pedido recomenda-se relacionar todos os gastos com salários do pessoal envolvido com a compra e manipulação de materiais, sem exceção, para o período de um ano. Da mesma forma, os custos anuais com material e custos indiretos.

Com a instalação de um Centro de Distribuição - CD, o custo do pedido é reduzido visto que todas as compras passam a ser centralizadas em um único departamento e não mais dispersas em $n$ pontos de venda do varejo. Isto leva à diminuição da incidência de erros gerados pela multiplicidade de lojas. Tudo fica centralizado no $\mathrm{CD}$, ganhando mais precisão no processo e redução de erros. $\mathrm{O}$ contato feito com os fornecedores acontecerá também partindo de um único departamento e não mais de forma descentralizada, permitindo assim melhores negociações.

Esta tese evidencia os ganhos advindos da centralização de estoques em um Centro Distribuição para uma rede de varejo brasileira, abordando os custos logísticos de um modelo descentralizado - loja-a-loja -, assim como de um modelo centralizado, evidenciando a redução de custos deste último.

O próximo Capítulo, além de contextualizar a pesquisa com base no varejo brasileiro, apresenta detalhes sobre a empresa objeto deste estudo. Evidencia ainda os fatores de redução de custos que ocorrem quando da centralização de estoques, dissertando sobre os modelos de cálculo para os referidos ganhos. 


\section{A análise de economicidade de um Centro de Distribuição - uma estrutura analítica}

O problema de localização de Centros de Distribuição é tradicionalmente uma questão de minimização de custos relacionados ao transporte de produtos a diversos pontos. O início desta teoria é normalmente atribuído a Weber (1909) que pesquisou sobre a localização de uma única indústria entre as diversas fontes de matéria prima e seus consumidores. De acordo com Eiselt \& Laporte (1995), a visão weberiana dominou a literatura, até a contribuição de Hakimi (1964) que fez a distinção entre minimização da soma de custos (minisum objective) e minimização da distância máxima (minimax objective). Desde então um fluxo grande de literatura emergiu, assim como muitas pesquisas vindas de diversos autores, como mostrado em resenhas de Love et al. (1988), Brandeau and Chiu (1989), Drezner \& Hamacher (2001), Current (2004), Revelle \& Eiselt (2005), Reese (2006), Farahani \& Hekmatfar (2009), Mello et al. (2009),

No mundo contemporâneo, os processos de armazenagem tornaram-se elementos dinâmicos, assumindo muitas outras formas e funções além da simples guarda estática, em consonância com a evolução industrial que identificou vantagens econômicas associadas à especialização e centralização da produção em determinados pontos, e o desafio subsequente de desenvolver processos de distribuição aos consumidores.

O desenvolvimento da tecnologia de informação e comunicação - TIC tem contribuído para a otimização dos processos de centralização de estoques, permitindo a rápida transferência de dados entre clientes e fornecedores; a introdução de canais de distribuição alternativos; e profundas mudanças na forma tradicional do sistema de distribuição física. Varejistas têm desenvolvido projetos para a localização de Centros de Distribuição - $\mathrm{CD}$-, com benefícios significativos para seus parceiros em ambos os extremos de suas cadeias de suprimento, lojas e fornecedores. As lojas, à jusante, que constituem um dos extremos da cadeia, vivem a realidade de mais espaços em suas prateleiras, operando com baixo custo e baixo back order em seus displays, enquanto os 
fornecedores, à montante, no outro extremo da cadeia, vivenciam o desafio de grandes reduções no custo do transporte devido a entregas centralizadas para a periferia de uma grande cidade, entregando em Centros de Distribuição que operam 24 horas por dia, deixando de desperdiçar tempo de espera nas entregas fracionadas. A entrega centralizada traz também uma redução no valor gasto com combustível e a diminuição do enfrentamento de congestionamentos nos centros urbanos onde ficam localizadas as lojas da rede.

As vantagens advindas da adoção de Centros de Distribuição são evidentes, desde vantagens operacionais, a profundas repercussões nas rotinas atuais e reduções nos custos administrativos. Cabe notar que as vantagens dos CDs não ficam restritas somente às grandes redes, mas podem ser também aproveitadas pelas pequenas, desde que devidamente assistidas por operadores logísticos.

O gerenciamento da distribuição física é certamente um grande desafio logístico e em atenção a esse desafio foi criado em Illinois, em 1963, o Council for Physical Distribution Systems (CPDS). Com a progressiva evolução do escopo da logística contemporânea, o nome desse Conselho foi alterado em 1965 para Council of Logistics Management (CLM), e em 2004 para Council of Supply Chain Management Professionals (CSCMP), com sucessivas atualizações da definição de seu escopo.

Este capítulo, baseado em trabalhos publicados por Starr \& Miller (1962), Maister (197), Eppen \& Schrage (1979), entre outros, disserta sobre os fatores econômicos considerados como vantagens na implantação de um Centro de Distribuição, tais como: (i) redução no custo do transporte, decorrente de transportes consolidados ao $\mathrm{CD}$; (ii) redução dos custos com estoques nas lojas, liberando espaços para exposição de produtos e estacionamento; (iii) centralização dos controles, visto que a recepção e verificação de produtos passa a acontecer em um único lugar e não fragmentado por lojas; (iv) diminuição do manpower utilizado para recepção e guarda de mercadorias nas lojas em razão de um processo que apresenta significativos ganhos de escala e $(v)$ redução da incidência de falta de produtos.

São também apresentadas características do varejo brasileiro e, em maior detalhe, características da empresa que é objeto deste estudo, além do papel que esta exerce no varejo brasileiro. 


\section{1}

\section{Informações sobre o varejo brasileiro e a empresa estudada}

Retroagindo na história da humanidade, constata-se que os primeiros comerciantes costumavam ir ao encontro de seus clientes ou selecionavam seus locais de trabalho de acordo com sua própria conveniência, sem grande preocupação com a vizinhança.

Com o crescimento das cidades, no entanto, eles perceberam as vantagens de se estabelecerem em locais que apresentavam uma alta concentração de atividades. Agrupados, os comerciantes poderiam atrair mais compradores, beneficiando em conjunto consumidores e a si mesmos.

Esta evolução determinou construções permanentes, a fim de abrigar o comércio local. Mais tarde, essas construções, mais desenvolvidas assumiram a forma de galerias, geralmente localizadas no centro das cidades. Em meados do século XX, dois cenários apareceram no mundo ocidental, especialmente nos Estados Unidos: uma intensa urbanização e o uso generalizado do automóvel.

O progresso global trazido pelo fim da Segunda Guerra Mundial determinou a evolução da indústria de varejo. A deterioração progressiva dos centros urbanos e a preferência dos consumidores para estacionar seus carros perto dos centros comerciais trouxe novos desafios para auxiliar os clientes. (ROZENTAL \& PIZZOLATO, 2012).

Certamente, os grandes aglomerados urbanos do Brasil não são equivalentes aos da América do Norte, porque o carro aqui não é acessível a todos e as estradas congestionadas são um impedimento para longas viagens com o objetivo de fazer compras de rotina.

O impacto econômico de varejo tem sido cada vez maior, principalmente devido à sua concentração através de processos de fusão e aquisição que alteram o equilíbrio de poder fornecedor-varejista em favor deste último. Este é certamente o caso do setor varejista brasileiro, que apresenta um cenário altamente competitivo, em que grandes grupos nacionais e estrangeiros estão adquirindo cadeias menores, a fim de obter economias de escala e aumentar o seu market share. Em 2008, este segmento foi responsável por quase 12\% do PIB - Produto Interno Bruto - do país, empregando mais de 8 milhões de pessoas; três grandes 
cadeias varejistas encontram-se entre as 20 maiores empresas brasileiras. (IBGE, 2010).

Estes investimentos em expansão estão sendo acompanhados de outras melhorias nos processos de logística e tecnologia da informação, com destaque para o foco na melhoria da eficiência operacional. O aumento da concorrência no setor é benéfica para o cliente, trazendo não só menores preços, mas também diferenciais em relação à qualidade de serviço, opções de pagamento, e maior variedade de produtos.

O setor de varejo tem um papel significativo a desempenhar, devido ao seu poder econômico global e sua posição privilegiada entre a oferta e a demanda. De fato, os varejistas podem influenciar tanto a produção quanto os padrões de consumo em todo o mundo. Do lado da oferta, cada vez mais a geografia e características da produção são moldadas por investimentos varejistas multinacionais.

Portanto, Illes (2007) afirma que os varejistas podem ter uma enorme influência em suas cadeias de fornecimento mundiais e locais, como resultado de suas estratégias de sustentabilidade que moldam várias decisões e atividades, tais como o desenvolvimento de novos produtos, estratégias de recursos humanos, condições de aquisição, produção e aspectos de distribuição e os padrões de embalagem.

Do lado da demanda, os varejistas tem o poder de influenciar a vida dos consumidores e o seu padrão de consumo - o que eles compram, usam e descartam. (McGOLDRICK, 2002). A disputa pelo consumidor, cada vez mais exigente e informado, que tem à disposição uma oferta crescente de artigos e que apresenta diferentes perfis e hábitos, está gerando uma multiplicação de estratégias e certa convergência de formatos no varejo.

Atualmente, tanto a nível mundial quanto nacional, a intensa concorrência tem levado a redefinições de cada tipo de loja ou serviço oferecido, cada um ampliando suas atividades tradicionais na direção de funções características de outros formatos ou dedicando-se a nichos específicos de mercado.

Varejo integra funções clássicas de operação comercial: aquisição, distribuição, marketing e entrega. Ele absorve mão de obra tradicional, historicamente exigindo mais educação formal e menos qualificação técnica que 
os empregados do setor industrial, mas geralmente tem uma oferta maior de empregos, se comparado à indústria. $\mathrm{O}$ varejo tem uma forte suscetibilidade às políticas econômicas e o volume de vendas tende a reagir rapidamente às mudanças no ambiente macroeconômico e à maioria dos indicadores de renda do consumidor.

O grupo objeto deste estudo atua como uma estrutura de atendimento multicanal. Além da rede de lojas físicas, a companhia chega a seus clientes com um amplo sortimento de produtos e serviços, comercializados via internet, televisão, televendas, catálogos e quiosques.

A empresa do grupo que motivou este trabalho é uma das TOP 5 do varejo físico no Brasil e está listada na Bolsa de Valores, Mercadorias e Futuros (BM\&F BOVESPA) desde 1940. A companhia possui uma base acionária composta por ações ordinárias e ações preferenciais.

Conta com um Conselho de Administração formado por oito membros, sendo cinco indicados pelos controladores, um indicado pelos acionistas minoritários e dois indicados pelo Conselho de Administração. Conta ainda com um Conselho Fiscal formado por três membros, sendo dois indicados pelo controlador e um indicado pelos acionistas minoritários.

A empresa foi fundada há quase 100 anos no Rio de Janeiro e está presente em todas as regiões do país ( 25 estados mais o Distrito Federal), com 621 lojas 389 no formato Tradicional e 232 em formato Loja-Bairro - equivalentes a 621 mil metros quadrados de área de vendas.

Em 2011, a Companhia havia estabelecido um novo recorde, tendo inaugurado 90 lojas - 62 no modelo Tradicional e 28 no modelo Loja-Bairro.

As lojas tradicionais possuem área média de vendas de 1.400 metros quadrados, reposição diária de estoques e aproximadamente 60 mil itens à venda. O modelo Loja-Bairro segue o conceito de lojas menores, com área média de vendas de 400 metros quadrados, logística just-in-time e sortimento selecionado em torno de 15 mil itens, adequado às características de cada localidade e ao perfil dos clientes dessas lojas. O Gráfico 2 evidencia a evolução do número de lojas da rede. 


\section{Evolução Área de Vendas $\times \mathbf{N}^{\circ}$ de Lojas} Posição em 31 de Dezembro

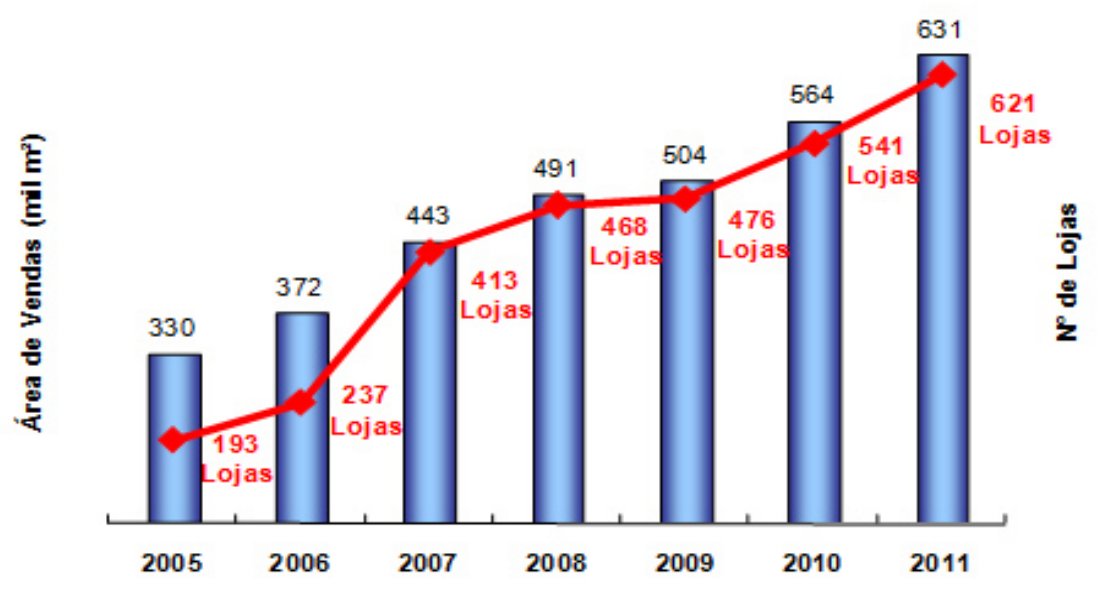

Gráfico 2: Evolução área de vendas $x \mathrm{n}^{\circ}$ lojas.

Fonte: Relatório de Administração de 2011 da empresa estudada

Entre os anos de 2000 e 2009 a empresa cresceu em cinco vezes o número de lojas, em seis vezes a receita bruta consolidada e aproximadamente 140 vezes a geração de caixa operacional consolidada (EBTIDA - Earnings Before Interest, Taxes, Depreciation and Amortization), saindo de uma margem EBITDA consolidada ( $\%$ RL) de $0,6 \%$ para $13,2 \%$ o que demonstra solidez na estratégia de crescimento e reforça as oportunidades existentes no país.

Para atingir esse crescimento recorde a empresa conta com a capacidade de execução de seus associados, sua expertise na localização e negociação de novos pontos, seus sistemas logísticos para distribuição das mercadorias e seu programa de recrutamento e treinamento de talentos.

Os informativos financeiros podem ser observados nos Gráficos 3(a) e 3(b).
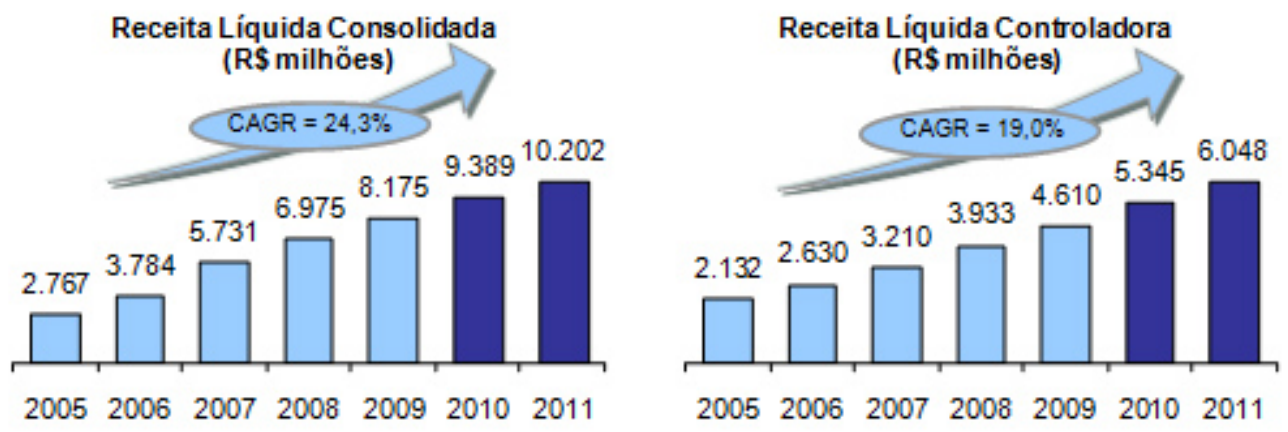

Gráficos 3(a) e 3(b): Informativos financeiros da empresa estudada. Fonte: Relatório anual da empresa (2011) 
Para isso são necessários investimentos constantes. $\mathrm{O}$ investimento da controladora da empresa no ano de 2012, foi de um total de $\mathrm{R} \$ 346,6$ milhões, com ênfase em: expansão, reforma da rede de lojas e atualização tecnológica. Neste total estão considerados os investimentos em bens destinados a aluguel. A Tabela 2 detalha a distribuição dos investimentos no ano de 2011.

Tabela 2: Distribuição dos investimentos da empresa controladora.

\begin{tabular}{|lll|}
\hline & $\begin{array}{l}\text { R\$ } \\
\text { milhoes }\end{array}$ \\
\hline Inaugurações/ Obras de melhoria & 290,8 & $83 \%$ \\
\hline Tecnologia / Logística / Operações & 35,9 & $10 \%$ \\
\hline Bens destinados a aluguel & 22,9 & $7 \%$ \\
\hline TOTAL & 349,6 & $100 \%$ \\
\hline
\end{tabular}

Fonte: Relatório da empresa estudada

A empresa garante a seus clientes preços competitivos em relação à concorrência e oferece produtos de qualidade reunidos nas seguintes unidades de negócio, produtos para Utilidade Doméstica, Lazer, Beleza, Infantil, Confecção e Alimentos de Conveniência, oferecendo produtos de grandes marcas com preços competitivos. Há uma grande variedade de produtos e grandes volumes são distribuídos por suas lojas. Há períodos de sazonalidade alta durante todo o ano para a empresa, além de Natal Páscoa, Dia das Crianças e Dia das Mães.

A venda de produtos é feita diretamente ao consumidor final com características predominantes de self-service, através de uma rede de lojas nas principais cidades de quase todos os estados do país.

A empresa possui também três Centros de Distribuição no Brasil para escoamento da sua distribuição. Estes Centros tem uma área de aproximadamente $45-50.000 \mathrm{~m}^{2}$ e abastecem as lojas diariamente. Somente os produtos perecíveis e de Páscoa são abastecidos diretamente pelos fornecedores. 
Para a evidência deste estudo avalia-se o Centro de Distribuição RJ desta rede de varejo brasileira que atende as lojas da região sudeste do Brasil, totalizando um número de aproximadamente 100 lojas, que vão desde a região metropolitana do Rio de Janeiro, até lojas localizadas no Triângulo Mineiro.

Como mencionado anteriormente, este estudo toma como base as redes de varejo que possuem lojas de departamento com produtos não perecíveis. Mas vários outros setores econômicos enfrentam um problema semelhante; um caso específico são os supermercados que lidam com mantimentos, produtos frescos, e perecíveis. A maioria destas redes usa Centros de Distribuição, mas a vida curta dos produtos requer um procedimento de entrega rápido, incluindo o envio direto de fornecedores para lojas.

Em termos da distribuição física de uma cadeia de varejo, o Centro de Distribuição tem a função de um armazém regional, onde cargas consolidadas de múltiplos fornecedores são recebidas, descarregadas e, sempre que necessário, reposicionadas para abastecer seus próprios pontos de venda. Entre o CD e cada loja o transporte é feito com cargas fracionadas e caminhões menores para reabastecer as quantidades exatas exigidas. Além disso, esse transporte é visto como uma operação interna para a empresa, pois ao chegar às lojas os produtos vão direto para as gôndolas de exposição.

A próxima seção detalha os processos gerenciais e componentes de gestão da empresa estudada, baseado no modelo apresentado no capítulo 2 .

\section{2}

\section{A empresa - seus processos gerenciais e componentes de gestão}

As ligações entre os processos de negócios são feitas através dos componentes de gestão, os quais são comumente encontrados nas empresas. Para esta pesquisa em si, e indo de encontro ao que já foi explicitado no Capítulo 2 deste trabalho, são destacados somente alguns processos gerenciais da empresa foco que são relevantes para o presente estudo e irão de encontro ao objetivo central deste trabalho, a saber, (a) Gestão da demanda (b) preenchimento do pedido e, (c) supplier relationship management. 
(a) Gestão da demanda

A empresa tem como premissa o atendimento de camadas populares. $\mathrm{O}$ público-alvo da loja é o cliente ocasional, que busca produtos baratos e, muitas vezes, em situações emergenciais. Os pontos de venda estão inseridos num macro ambiente favorável, em que o poder aquisitivo da população é crescente, bem como a exigência de qualidade e sortimento dos produtos.

Opera com um sistema de auto-serviço e apesar de os vendedores terem informações sobre os produtos, não chegam a ser técnicos. Também não são persuasivos e funcionam como gerente de clientes, pois eles têm o dever de manter o bom relacionamento com o consumidor. O principal fator é poder oferecer ao consumidor diversas soluções de compra em um só espaço, portanto, o sortimento deve ser extenso.

A empresa gera e coleta informação em massa através de seus PDVs (Pontos de venda - caixas registradoras, neste caso), em tempo real. À medida que seus produtos são vendidos as informações contidas nos códigos de barra são coletadas e armazenadas. Estas informações possibilitam a análise em curto espaço de tempo e em diversas variações - por loja, por grupo de produtos, ou por um produto específico - sendo possível analisar o hábito de compras do consumidor, o impacto de promoções, o sucesso no lançamento de um novo produto, além de prever o volume de vendas com precisão. Através deste sistema é também possível fazer um planejamento de vendas futuras.

\section{(b) Preenchimento do Pedido}

A utilização da tecnologia de automação dos PDVs está associada ao uso de um intercâmbio eletrônico de dados - EDI, onde os fornecedores podem ver em tempo real as vendas que aconteceram. Isto desencadeia a rápida reposição do estoque consumido. Em circunstâncias normais, em que há disponibilidade do produto em estoque, o fabricante imediatamente coletará o item de reposição do estoque e fará o planejamento logístico da entrega do mesmo ao varejista.

Somente alguns fornecedores, entretanto, estão conectados via EDI, sendo os demais pedidos feitos através da internet, via email. 


\section{(c) Supplier Relationship Management}

Por ter o grupo uma rede de lojas em todo o Brasil, além de tele-vendas e $e$ commerce, a empresa tem contato com diversos fornecedores e possui um alto poder de negociação com os mesmos. Desta forma, segundo afirma Porter (1980), existem algumas justificativas que aumentam o poder de barganha do varejista junto ao fornecedor, a saber: a empresa focal do presente estudo adquire grandes volumes em relação ao share de mercado que participa; os produtos que adquire representam uma fração significativa de suas compras; os produtos que compra são padronizados ou não diferenciados e, ainda, ele - o varejista -, não é uma ameaça de integração à montante para o fornecedor.

Vale também ressaltar que, no caso de varejistas, os mesmos têm o poder de influenciar a decisão de compra de seus consumidores, sendo uma grande fonte de barganha junto aos seus fornecedores, que sabedores disto ficam abertos à negociação de preços para fornecimento.

Há entre a empresa focal e seus principais fornecedores uma preocupação forte com a parceria. Dentro deste segmento se faz presente um canal muito aberto às negociações.

Entre os componentes de gestão mais visíveis e tangíveis, chamados de componentes de gestão físicos e técnicos, enquadram-se os métodos de planejamento e controle, estrutura de trabalho, estrutura organizacional, estrutura do fluxo de comunicação e de informação das cadeias e estrutura do fluxo de produto da cadeia.

Para a empresa em estudo, constatou-se que:

(i) Métodos de Planejamento e Controle - Esses métodos se encontram presentes nas técnicas adotadas para ajudar no planejamento e execução conjunta das atividades, tais como: compras, contas a pagar e receber, contabilidade, na realização de atividades de apoio, como contato com o prestador de serviços de transporte, entre outras, visando o bom andamento da operação do negócio. As técnicas de controle de tempo, de quantidade e de recursos corretos para um bom desempenho da cadeia também fazem parte desse componente. Para auxiliar a gestão do dia-a-dia, a empresa focal utiliza-se de ferramentas e softwares tais 
como, Office, SAP/ERP, EDIs E PDVs.

(ii) Estrutura de trabalho e de atividades - A empresa focal tem uma estrutura de trabalho que acontece baseada em uma cadeia interna com visão sistêmica, onde as áreas trabalham de forma integrada. $\mathrm{O}$ sistema de gestão integrada auxilia no compartilhamento de informações entre os departamentos, o que eleva o nível de atendimento dos clientes e fornecedores internos da empresa. Essa mesma filosofia é transmitida para que seja prática quando do contato com clientes e fornecedores externos.

(iii) Estrutura Organizacional - Foi possível constatar que a empresa é administrada por um Conselho de Administração e um grupo de diretores. $\mathrm{O}$ referido conselho estabelece comitês para melhor desempenho de suas funções e tem poder para eleger e destituir qualquer diretor. Os comitês são divididos em: comitê de finanças; comitê de gente e remuneração e comitê digital. Há ainda um Conselho Fiscal que tem funcionamento não permanente e possui poderes e atribuições que a lei confere.

(iv) Estrutura do fluxo de produtos da cadeia - Esse componente de gestão apresenta como seu principal elemento o estoque ao longo do processo. $\mathrm{O}$ estoque de todas as lojas da rede fica centralizado no Centro de Distribuição depois de recebidos dos seus fornecedores. As lojas somente recebem diretamente do fornecedor os produtos de utilização rápida ou perecíveis - como itens de bomboniére. O Centro de Distribuição abastece as lojas diariamente ou, no máximo em três dias - lojas mais distantes - e o fornecimento para o Centro de Distribuição acontece em prazo variado, dependendo de cada fornecedor. Alguns produtos são recebidos como cross-docking no Centro de Distribuição, e nem mesmo passam pelos seus estoques físicos, somente contábeis.

(v) Estrutura do fluxo de comunicação e de informação da cadeia - A troca de informações ao longo da cadeia demonstra-se bastante eficiente. A tecnologia auxilia bastante os processos internos e externos. Internamente, o ERP da empresa auxilia na troca de informações entre as áreas, facilitando o 
gerenciamento de informações específicas da organização e de algumas unidades de negócio. Externamente, tanto o PDV quanto o EDI auxiliam na armazenagem e envio de informações, fornecendo, por um lado, à empresa, um planejamento mais efetivo das suas vendas e, por outro lado, entregando aos fornecedores informação rápida e precisa quanto à necessidade de reposição de estoque.

Os componentes de Gestão Gerenciais e Comportamentais menos tangíveis e visíveis, mas que influenciam - componentes físicos e técnicos - devem ser implantados, pois definem o comportamento organizacional. São eles: os métodos de gestão, estrutura de poder e liderança, estrutura de risco e recompensa e cultura e atitude.

A seguir pode-se verificar como tais componentes gerenciais e de gestão acontecem na empresa focal:

(i) Métodos de Gestão - Em todos os níveis da estrutura organizacional as gerências e diretorias se envolvem e se integram. Os processos acontecem de forma holística e a empresa estabelece como um dos parâmetros fundamentais a visão sistêmica na análise da organização e de seus processos, evitando com isso ruídos ao longo da cadeia interna. Isto possibilita que seus colaboradores atuem da mesma maneira quando se relacionam com a cadeia externa.

(ii) Estrutura de Poder e Liderança - Nesta cadeia a empresa focal apresenta um grande poder na cadeia à montante, já que é uma das TOP 5 do varejo brasileiro. O poder de barganha dos fornecedores não é elevado. Há, entretanto, um equilíbrio de poder entre a empresa foco e seus concorrentes. Internamente, a hierarquia apresenta uma estrutura funcional com menos unidades de comando, ampliando o controle das remanescentes e promovendo a comunicação e integração contínuas entre as áreas.

(iii) Cultura e Atitude - Como não há diversidade neste segmento, o equilíbrio entre cultura e atitude permite o sucesso da operação. A empresa foco possui uma cultura organizacional forte que visa constantemente a integração e sinergia entre os colaboradores. Desenvolve um senso de pertencimento quando estabelece a meritocracia no propósito de incentivar seus colaboradores. Adota 
ainda políticas de crescimento para que os mesmos assumam importantes responsabilidades em um curto período de tempo.

$\mathrm{Na}$ próxima seção deste capítulo apresentam-se os fatores que fornecem redução de custos em uma centralização de estoques.

\section{3}

\section{Elementos que promovem redução de custos}

As empresas dedicam muito tempo procurando meios para diferenciar seus produtos dos de seus concorrentes. Quando a gerência reconhece que a logística afeta uma parte significativa dos custos da empresa e que o resultado das decisões tomadas sobre a cadeia de suprimentos leva a diferentes níveis de serviços ao cliente, ela está em condições de usá-la de maneira eficaz para penetrar em novos mercados, ampliar o market share da empresa, e elevar os lucros.

Os acordos comerciais multilaterais, a globalização, a evolução da tecnologia e a mudança de hábitos dos consumidores são variáveis externas que colocam as organizações em xeque, desafiando suas decisões e sua capacidade de construir estratégias vencedoras e de sobrevivência. Os desafios estratégicos são enormes. As situações de mercados se revelam cada vez mais difíceis, principalmente no setor de varejo devido à competição intensa, entrada de novos players nacionais e internacionais, variação na participação de mercado, regras impostas pelo governo e problemas financeiros.

A cadeia de suprimento tem recebido atenção especial das organizações quando da elaboração de sua estratégia, sendo o mercado consumidor o grande impulsionador destas estratégias. A SCM exige uma visão sistêmica dos gestores e apresenta enormes desafios, no entanto, para vencer na era em que o grande foco é a parceria em todos os elos da cadeia, a capacidade imaginativa dos líderes e profissionais que atuam na área tem sido cada vez mais exigida.

A Figura 9 evidencia todos os fatores que devem ser considerados em uma estratégia para a gestão da cadeia de suprimentos. 


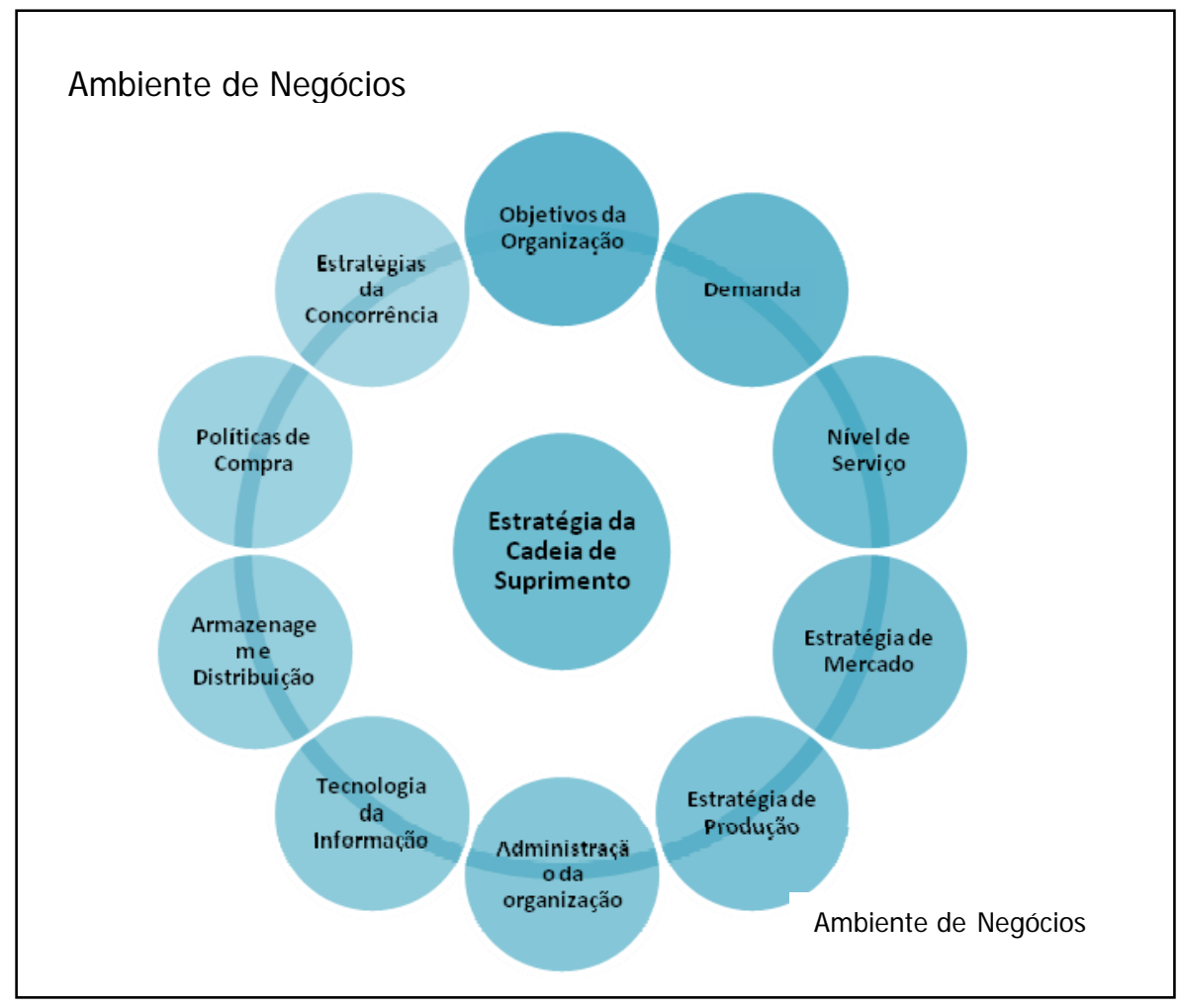

Figura 8: Fatores satélites da Cadeia de Suprimentos. Fonte: Adaptado de Christopher (2000)

A distribuição física de produtos é uma tarefa complexa tanto para os agentes produtores, que buscam atender aos clientes, como para os agentes intermediários que os compram para fins de comercialização. Em ambos os casos a distribuição física é parte de um conjunto integrado de decisões que envolvem níveis de serviços aos clientes, padrões de estoque, organização do transporte e políticas de compras e vendas. Todo esse conjunto de decisões visa prover um fluxo eficiente de materiais e produtos ao longo de toda a cadeia de suprimentos em direção aos clientes.

Como a criação de um CD tornou-se uma necessidade para toda a rede de varejo, organizações fazem estudos de análise de viabilidade operacional e financeira da implantação de um Centro de Distribuição com vistas a centralizar os estoques.

Algumas se defrontam com a decisão estratégica quanto ao número de CDs a implantar, assim como a melhor localização e quais clientes atender a partir de cada um deles. Segundo Erlebacher \& Miller (2000), um dos objetivos que a empresa deve avaliar é o de manter um nível de serviço aceitável, mas 
minimizando os custos operacionais do $\mathrm{CD}$, os custos dos estoques de segurança, os custos de transporte entre fornecedores e CDs, e destes aos clientes finais.

Para as redes de varejo, um $\mathrm{CD}$ assume diversas funções que seriam exercidas pelas múltiplas lojas, desde a de centralizador das compras e do relacionamento com os fornecedores até as funções de receptor, controlador de produtos comprados, e seu armazenamento para posterior entrega a sua rede de lojas, quando se tornar necessário repor os produtos consumidos pelos clientes finais.

Os CDs promovem ainda ganhos diversos, pois em todas as funções desempenhadas existe um ganho de escala ao concentrar atividades dispersas pelas lojas em uma única instalação. Estas diversas fontes de redução de custos são destacadas como principais drivers deste trabalho, a saber: os custos de transporte, de estoque, de mão de obra, assim como os custos de liberação de espaço nas lojas e o custo da falta de produto. Tais drivers são apresentados, detalhadamente, nas seções que se seguem:

\subsection{1}

\section{Redução no custo de transporte}

O desafio para os gestores logísticos há muito se prende ao fato dos clientes exigirem um nível de serviço elevado não querendo, entretanto, pagar a mais por isso. O preço está passando a ser um qualificador, e o nível de serviço, um diferenciador, perante o mercado. Assim, a logística ganha a responsabilidade de agregar valor ao produto por meio do serviço por ela oferecido.

E o transporte tem sido um balizador importante no que tange ao trade off redução de custos e aumento do nível de serviço.

Sob a perspectiva da Cadeia de Suprimentos, faz-se necessária a implementação de parcerias logísticas efetivas entre as empresas, que prezem pela estratégia do "ganha-ganha", principalmente no que tange aos custos com transporte, estabelecendo assim um ambiente de confiança mútua entre as partes.

No caso de um Centro de Distribuição, para avaliar os custos de transporte, deve-se dizer que a sistemática do processo consiste em receber e armazenar no $\mathrm{CD}$ os volumes recebidos dos fornecedores e abastecer as lojas com caminhões 
menores, à medida que ocorrem as vendas, com produtos conferidos e já internalizados à rede.

O abastecimento das lojas da rede estudada costuma se enquadrar em uma política, tipo $D+k$, onde $k=1,2$ ou 3. Essa política significa que todas as vendas ocorridas na data $D$, por determinada loja, serão ressupridas $k$ dias mais tarde. Naturalmente, o valor $k=1$ é reservado para as lojas nas regiões circunvizinhas, $k=2$ para as regiões próximas e $k=3$ para lojas em regiões relativamente distantes. Cabe ressaltar que o custo do transporte do $C D$ às lojas, já dentro do ambiente da rede varejista, é assumido pela própria rede, enquanto o custo do transporte desde o fornecedor aos CDs deve se tornar objeto de negociação, diante dos significativos ganhos econômicos observados nos trajetos entre fornecedores e os CDs, como justificado Nas Figuras 9(a) e 9(b).

A adoção de um Centro de Distribuição remete de imediato a uma redução nos custos globais do transporte. As Figuras 9(a) e 9(b) ilustram essas alternativas. $\mathrm{Na}$ opção 9(a) o fornecedor atende diretamente um grande número de lojas, muitas das quais recebem cargas pequenas ou fracionadas, enquanto na opção 9(b) é feito o transporte de grandes volumes em longos trajetos do fornecedor aos depósitos intermediários, e volumes menores deverão seguir dos depósitos às lojas, porém em trajetos reduzidos.

O presente raciocínio sugere que a grande redução de custos seria quase toda apropriada pelos transportadores associados aos fornecedores, que trocariam um grande número de viagens, com entregas fracionadas aos muitos clientes, por um número bem menor de viagens consolidadas aos poucos depósitos, enquanto que a rede assumiria as viagens destinadas aos ressuprimentos das lojas. Certamente, a percepção da enorme economia gerada aos fornecedores pode servir de elemento de negociação sobre fretes. 

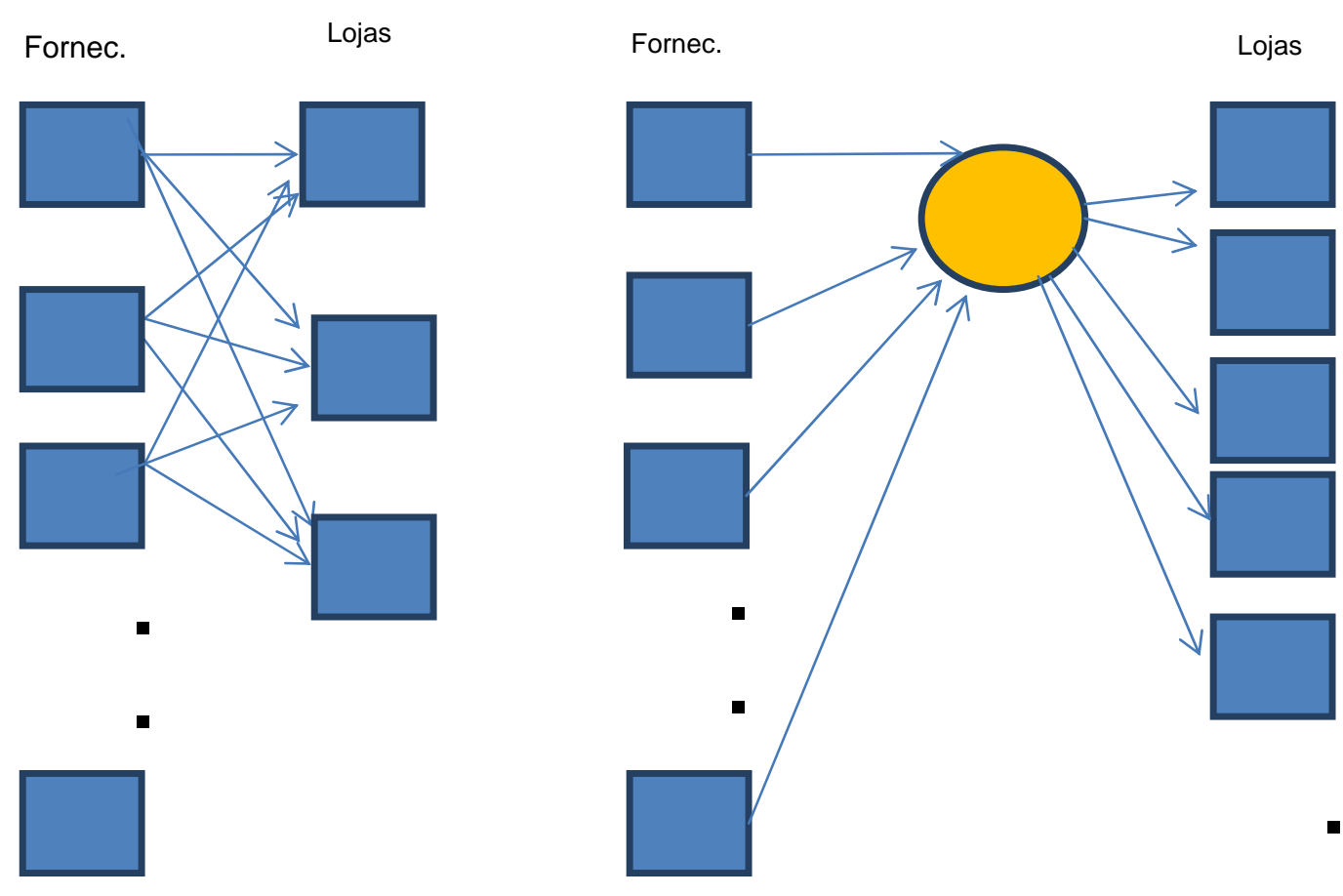

(a) Entregas diretas

(b) Entregas aos CDs

Figura 9: Comparativo entre $\mathrm{n}^{\circ}$ de viagens com e sem CDs. Fonte: a autora

Suponha uma estrutura com um $\mathrm{CD}, n$ lojas e $f$ fornecedores, e sejam $c_{1}$ o custo unitário consolidado entre os fornecedores e o $\mathrm{CD}, c_{2}$ o custo unitário da carga fracionada entre os fornecedores e as lojas, sendo, tipicamente, $c_{1}<c_{2}$. Seja ainda $c_{3}$ o custo de transporte unitário entre o $\mathrm{CD}$ e as lojas, valor em média muito inferior aos demais custos unitários, por se tratar de trechos curtos, feitos com veículos leves e com procedimentos de descarga mais rápidos. Suponha ainda que as lojas sejam visitadas diariamente, totalizando cerca de 300 viagens anuais a cada loja. Com esses dados, o número de viagens anuais nas situações 9(a) e 9(b), seriam, respectivamente: $12 n f$; e $12 f+300 n$.

Comparando-se ambos os valores, tem-se que a quantidade de viagens previstas nos dois sistemas se igualariam caso $n=f /(f-25)$. Portanto, caso $f>300$, basta um número ínfimo de lojas, como $\mathrm{n} \geq 2$, para a estrutura centralizada em um $\mathrm{CD}$ reduzir o número total de viagens. Caso $\mathrm{f}=50$ fornecedores bastariam $\mathrm{n}=2$ lojas para igualar o número de viagens e, se $\mathrm{f}>50$, qualquer valor de $n$ superior a 2 seria suficiente. 
Levando-se em conta o custo de cada viagem, a estrutura com CD torna-se ainda mais econômica, pois o valor $c_{1}$ tende a ser muito inferior a $c_{2}$.

Analogamente, na situação com três CDs, o ponto de equilíbrio seria dado pela equação $12 n f=36 f+300 \mathrm{n}$. Com isso, a quantidade de viagens previstas nos dois sistemas se igualariam caso $n=3 f /(f-25)$. Portanto caso $f>300$, basta um número ínfimo de lojas $n \geq 4$ para uma estrutura com três CDs reduzir o número total de viagens. Cálculo análogo para três CDs, incluindo os três coeficientes de custo, indicam que basta o número de lojas satisfazer a restrição: $\mathrm{n}>3 \mathrm{fc}_{1} /\left(\mathrm{fc}_{2}-\right.$ $25 \mathrm{c}_{3}$ ). Diante dos valores relativos dos coeficientes de custo, e supondo uma quantidade moderada de fornecedores, como $f>300$, a relação pode ser satisfeita a partir de valores muito baixos de $n$, como $\mathrm{n} \geq 2$.

Aliada a essa redução no número de viagens e dos custos correspondentes, há também que se considerar a diminuição das horas perdidas pelos caminhoneiros à espera da entrega das mercadorias nos pontos de venda. Levantamentos realizados pelo Centro de Estudo em Logística da COPPEADUFRJ, em diversas empresas brasileiras, determinaram um padrão elevado de ineficiência no transporte, sobretudo nas atividades de carregamento e descarregamento, em que os tempos de espera geralmente ultrapassam seis horas.

Com os CDs operando 24 horas ao dia em locais de fácil acesso, na periferia dos grandes centros urbanos, com mais espaço de manobra e menos restrições viárias e legais, este tempo de espera se reduziria, se comparado às lojas que exigem fortes restrições de acesso, assim como janelas de horários de entrega. Assim, o sistema de CDs, operando em áreas periféricas, com equipes permanentes, permite a racionalização dos processos de entrega, e sensível redução no tráfego nas regiões urbanas centrais.

\subsection{2}

\section{Redução no custo do estoque}

Uma das bases para o gerenciamento da cadeia de suprimentos é a gestão dos estoques de uma organização. Como a busca contínua pela redução dos estoques está invariavelmente associada ao aumento da eficiência operacional, tal 
redução, em particular, tem uma integração forte com armazenagem, procurement e transporte.

A definição de uma política de estoque depende de definições muito claras sobre o quanto pedir, quando pedir, quanto manter em estoque de segurança e, onde localizar.

Num mundo ideal, sem incerteza, a taxa de consumo médio diário $(d)$ dos produtos é totalmente previsível dia após dia. Desta forma, pode se saber exatamente quando o nível de estoque chegará a zero, ou seja, o momento do reabastecimento, quando devemos programar a chegada de novos produtos.

Basta desdobrar no tempo lead-time de ressuprimento (LT), a partir do momento do reabastecimento, e determinar o momento de pedir. O Ponto de Pedido (PP) é simplesmente o momento de pedir convertido para o nível de estoque através do resultado entre a taxa de consumo médio diário $(d)$ pelo leadtime de ressuprimento $(\mathrm{LT})=\left(d^{*} \mathrm{LT}\right)$.

Por outro lado, no mundo real (com incerteza) a taxa de consumo dos produtos não é totalmente previsível, podendo variar consideravelmente ao redor do consumo médio. Além disto, o lead time de ressuprimento também pode variar, ocasionando atrasos na entrega. Para se proteger destes efeitos inesperados, as empresas dimensionam estoques de segurança, além dos estoques operacionais, em função de uma probabilidade aceitável de falta de produto em estoque.

Outro elemento da dinâmica da gestão de estoques que permanece inalterado, independentemente dos motivadores à redução dos níveis de estoque, é o trade-off de custos existentes entre os estoques e outras funções logísticas.

Conforme se pode perceber na Figura 10, o objetivo da Cadeia de Suprimento com relação à gestão de estoques deve ser a determinação do tamanho do lote de ressuprimento mais apropriado ao seu nível de eficiência no processo de movimentação de materiais. Neste exemplo, o equilíbrio não se situa nem tanto à esquerda do gráfico, como nos sugere a Política 1 , nem tanto à direita, como nos sugere a Política 2. 


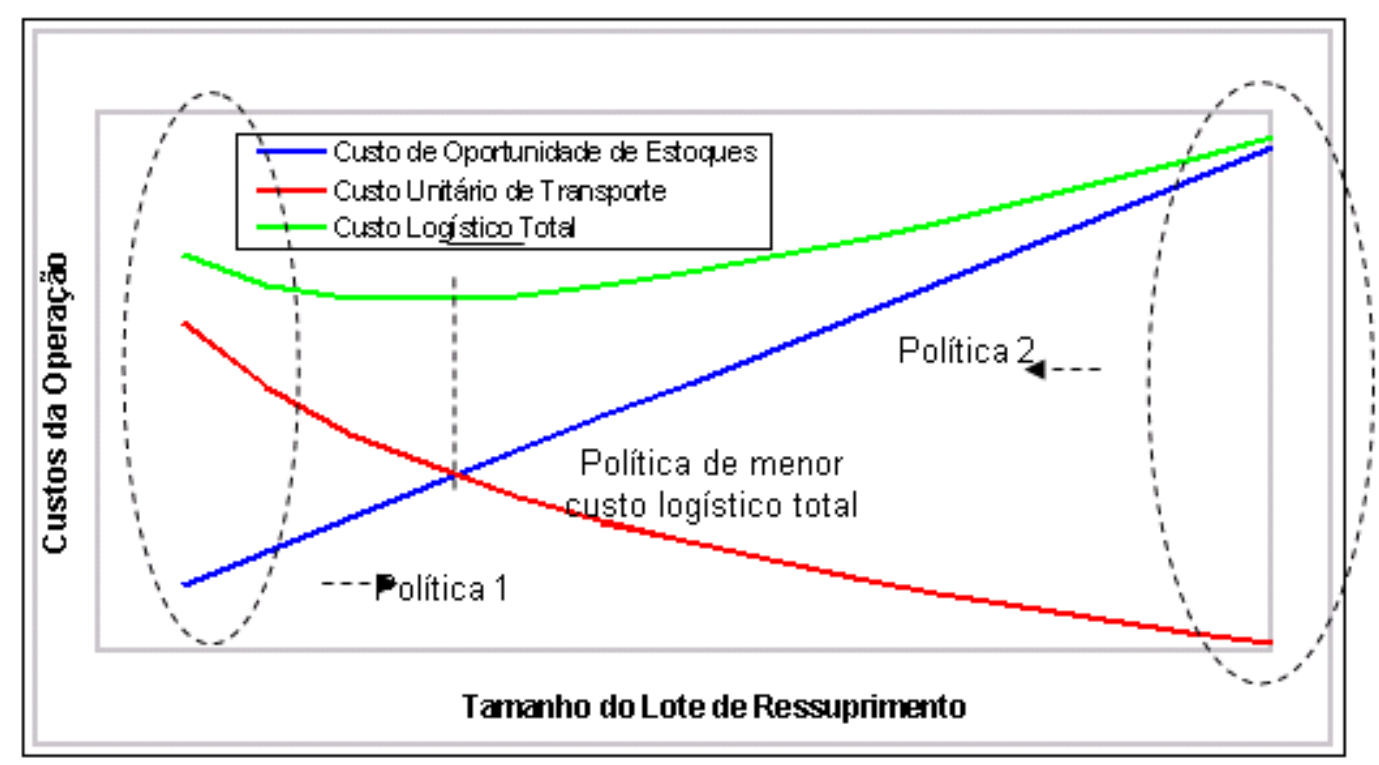

Figura 10: Política de ressuprimento adequada.

Fonte: ILOS (2012)

$\mathrm{Na}$ prática, é muito difícil para as empresas avaliarem adequadamente em que ponto do gráfico se situa sua atual política de estoques. Entretanto, é possível, através de geração de cenários e de análises incrementais nos custos de estoques e movimentação de materiais, determinarem se uma alternativa de operação acarretará um menor custo logístico total.

Desta forma, é possível evitar a percepção de que reduções isoladas nos níveis de estoque, sem serem levados em consideração impactos em outras funções logísticas, como transporte, armazenagem e processamento de pedidos, permitem uma operação de ressuprimento de menor custo total. Na realidade, conforme ilustrado pela Figura 10, as empresas devem buscar minimizar o custo logístico total de estoques, de transporte e de processamento de pedidos em função de uma determinada disponibilidade de produto desejada pelo cliente final.

O sistema mais tradicional de controle de estoques é conhecido como a fórmula do lote econômico (EOQ - Economic Order Quantity) Peterson \& Silver (1979). Esse modelo foi proposto por volta de 1925 e descreve bem os métodos de produção Taylorista da época. Entretanto o método continua sendo o mais simples e possivelmente mais útil dos métodos existentes. O modelo pressupõe que a demanda ocorra em ritmo constante e leva em conta, além da demanda anual, dois parâmetros: A, o custo de colocar um pedido, e $h$, o custo de manter em estoque. De acordo com este modelo, o nível de estoque segue um comportamento gráfico 
conhecido como dente de serra. Desse comportamento, deriva-se a conhecida expressão do lote econômico, $Q^{*}$, também mostrada na Figura 11.

O modelo repousa sobre as seguintes características:

(i) A demanda pelo produto é conhecida, constante e uniforme durante o período;

(ii) O "lead time" (L), tempo entre o pedido e o recebimento é constante.

(iii)O preço por unidade é constante, sem descontos por quantidade.

(iv)Os custos de pedido são constantes.

(v) Toda a demanda é satisfeita.

(vi)Não há interação entre produtos.

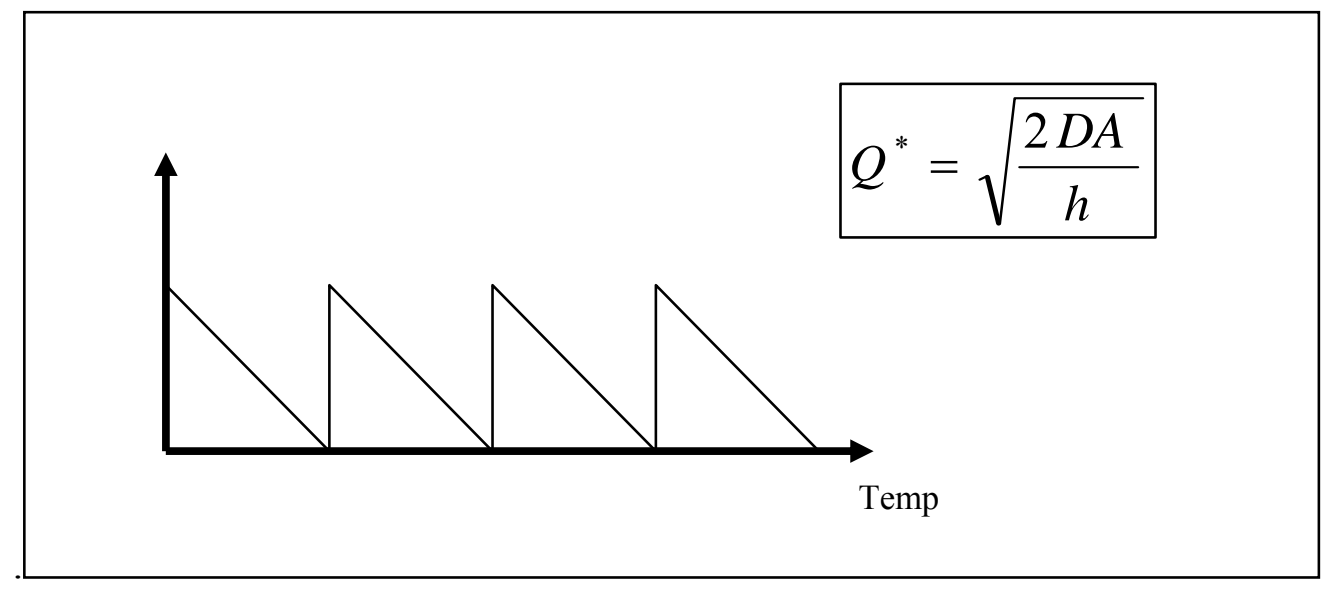

Figura 11: O lote econômico de compra.

Fonte: PETERSON \& SILVER (1979)

Onde:

$\mathrm{Q}=$ lote econômico

$\mathrm{D}=$ demanda anual observada em uma loja;

$\mathrm{A}=$ custo de encomendar cada pedido;

$\mathrm{h}=$ custo de manter em estoque por unidade-ano;

$\mathrm{Q}^{*}=$ quantidade ótima de cada pedido;

$\mathrm{CT}=$ custo total administrável dos estoques em uma loja;

$\mathrm{CT}_{\mathrm{n}}=$ custo total administrável dos estoques do conjunto de $n$ lojas;

$\mathrm{CT}_{\mathrm{CD}}=$ custo total administrável dos estoques concentrados em um CD. 
O custo total administrável dos estoques é dado pela expressão $C T$, cujo mínimo é exatamente encontrado para o lote econômico $Q^{*}$. A primeira parcela do lado direito indica o número de compras anuais ponderado pelo custo de cada compra, e o segundo termo leva em conta o estoque médio vezes o custo anual de manter em estoque, conforme Equação 1.

$$
C T=\frac{D}{Q^{*}} \cdot A+\frac{Q^{*}}{2} \cdot h
$$

(Equação 1)

Suponha agora um sistema constituído por $n$ lojas iguais e com idêntica demanda anual, ou seja, cada uma tem a demanda anual comum $D$, e os mesmos parâmetros administrativos: $A$ e $h$. Assim, o custo total das $n$ lojas seria dado pela Equação 2:

$$
C T_{n}=n \cdot C T
$$

Imagine agora o sistema operando com um $C D$ que atenda às $n$ lojas, e responsável pelo controle dos estoques de toda a rede. Para esse $C D$, a demanda observada pelo conjunto de lojas, ou demanda agregada, será $n D$, enquanto que os parâmetros poderiam ser admitidos os mesmos, pois não estariam afetados pela maior escala das compras. Aplicando-se o mesmo modelo do lote econômico, tem-se a Equação 3:

$$
Q_{C D}{ }^{*}=\sqrt{\frac{2 n D A}{h}}=\sqrt{n} \cdot Q^{*}
$$

Sendo $C T_{C D}$ a expressão do custo administrativo total, na ótica do $C D$, ela é obtida usando-se a demanda agregada e o lote econômico resultante, $Q_{C D}^{*}$, como acima definido. $\mathrm{O}$ custo total do $\mathrm{CD}$ pode ser evidenciado na Equação 4: 


$$
C T_{C D}=\frac{n D}{\sqrt{n} \cdot Q^{*}} \cdot A+\frac{\sqrt{n} \cdot Q^{*}}{2} \cdot h=\frac{\sqrt{n} \cdot D}{Q^{*}} \cdot A+\frac{\sqrt{n} \cdot Q^{*}}{2} \cdot h
$$

(Equação 4)

Desta forma, a razão entre os custos totais com os estoques das $n$ lojas isoladamente e o custo dos estoques com um $C D$ é verificado através da Equação 5:

$$
\frac{n \cdot C T}{C T_{C D}}=\frac{n \cdot\left(\frac{D}{Q^{*}} \cdot A+\frac{Q^{*}}{2} \cdot h\right)}{\sqrt{n} \cdot\left(\frac{D}{Q^{*}} \cdot A+\frac{Q^{*}}{2} \cdot h\right)}=\sqrt{n}
$$

O resultado acima proporciona uma significativa interpretação. Caso o lote econômico seja $\mathrm{Q}^{*}$ e o número de lojas $n=100$, todas observando demandas comuns e iguais a $D$, o custo total de administrar estoques aumentaria proporcionalmente a $n=100$, enquanto que com o uso do $\mathrm{CD}$ este custo administrativo evoluiria segundo a expressão $\sqrt{n}=10$, ou seja, $90 \%$ dos custos de administrar os estoques passariam a ser evitados.

Diversos trabalhos anteriores chegaram a conclusões análogas, embora usando métodos e hipóteses distintas (Zinn et al., 1989, Evers \& Beers, 1993 e Croxton \& Zinn, 2005). Starr \& Miller (1962) consideram estoques de segurança em $n$ depósitos e examinam a transferência de parte destes estoques para um depósito central e verificam os ganhos de escala. Os autores afirmam que o mesmo nível de proteção pode ser oferecido, mas com menor volume de estoque.

Maister (1976) demonstra a lei da raiz quadrada das locações, que estabelece que o estoque total de um sistema é proporcional à raiz quadrada do número de localizações nas quais o produto é estocado. Sua demonstração supõe também o uso do lote econômico de compras. Eppen (1979) parte do the newsboy problem, ou problema do pequeno jornaleiro, com demanda normal e examina o efeito de centralizar os estoques, e chega às seguintes conclusões: o custo de manter estoques e de sua falta em um sistema descentralizado é superior aos custos de um sistema centralizado; a magnitude das economias depende da 
correlação das demandas; e se as demandas são idênticas e não correlacionadas, os custos aumentam segundo a raiz quadrada do número de pontos de demanda. Nozick \& Turnquist (1998) estudaram a demanda de concessionárias de automóveis, sujeitas a demandas que seguem a distribuição de Poisson, e concluíram que, ao centralizar estoques, o nível de estoque necessário evolui segundo a raiz quadrada do número de concessionárias.

\subsection{3}

\section{Aumento do espaço nobre nas lojas}

Diante do cenário em que existe um número grande de lojas dispersas pela cidade - consequência da multiplicação dos pontos de venda do varejo -, o armazenamento de estoques nas lojas acarreta um custo elevado por um espaço que poderia ser destinado à mais exposição de produtos para o cliente final. Cabe notar que as lojas estão posicionadas em áreas valorizadas da cidade, enquanto que os CDs são construídos em áreas periféricas, a custos unitários muito inferiores.

Neste contexto, há um fator muito importante: o aumento do valor do $\mathrm{m}^{2}$. Segundo o FIPE (2012) poucos países tiveram uma valorização imobiliária comparável à do Brasil nos últimos anos. Até 2011, os preços subiram num ritmo anual de $20 \%$ a $30 \%$, em média, acima da renda nacional, a inflação e o rendimento de diversas aplicações. De acordo com o levantamento, os preços, continuam aumentando, mas de forma mais equilibrada. O Rio de Janeiro, entretanto, é a cidade que tem o valor de $\mathrm{m}^{2}$ mais caro do país; a valorização foi de $25 \%$.

A Figura 12 demonstra o valor do $\mathrm{m}^{2}$ na cidade do Rio de Janeiro. 


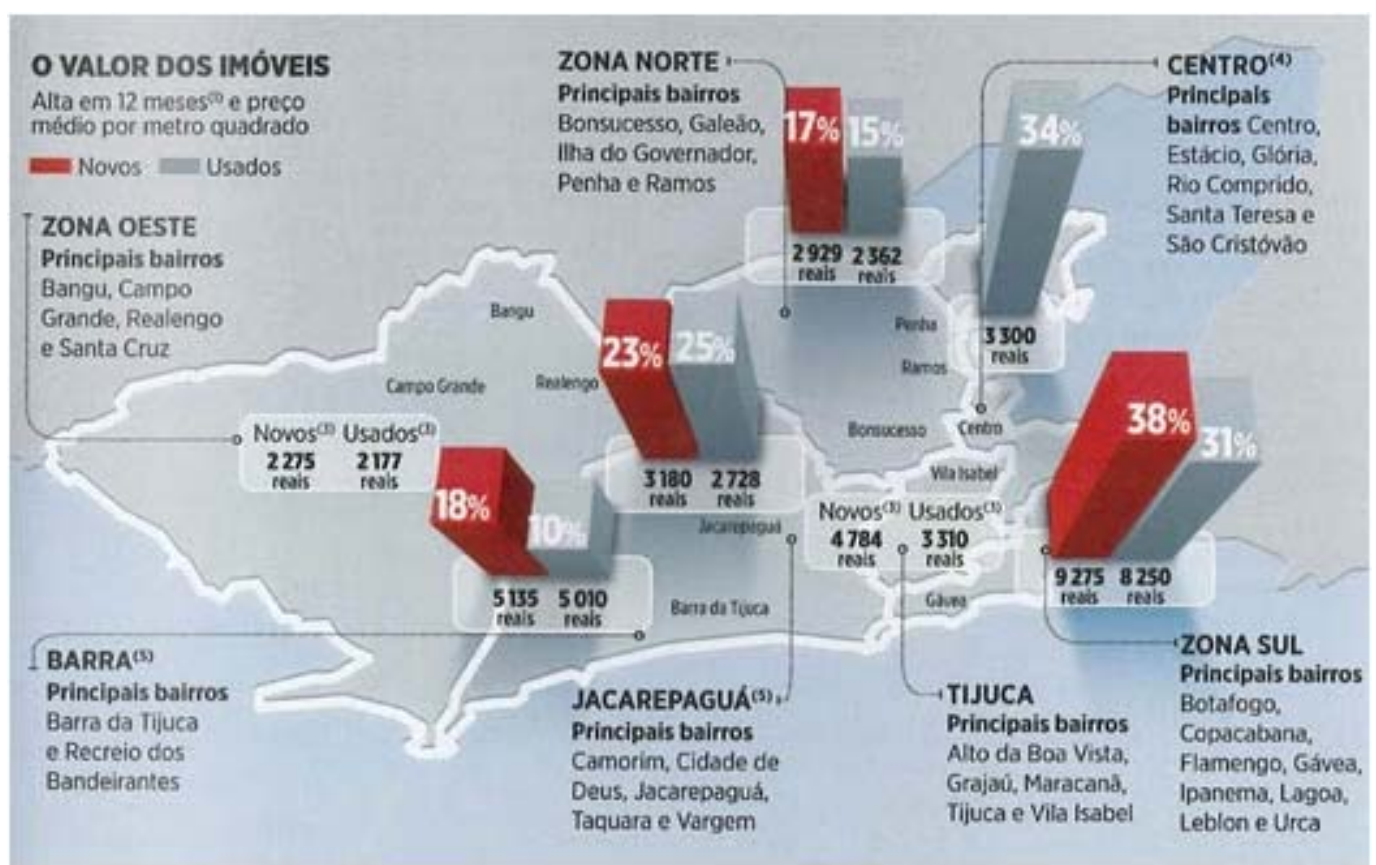

Figura 12: Mapa do Rio de Janeiro - Valor do $\mathrm{m}^{2}$. Fonte: FIPE

Suponha que uma rede de varejo possua $M \mathrm{~m}^{2}$ de área em cada uma de suas lojas para estoque/recepção de produtos. Portanto, se $n$ é o número de lojas, a área total necessária para armazenamento nos pontos de vendas seria de $n M \mathrm{~m}^{2}$. $\mathrm{O}$ custo correspondente seria obtido multiplicando-se essa área pelo custo médio do metro quadrado. Ao transferir tais estoques para o $\mathrm{CD}$ há uma notável redução de espaço exigido, pois, como mostrado na Seção 3.2, a área no CD tenderia a ser $\sqrt{n} M \mathrm{~m}^{2}$, e ainda, o custo unitário por metro quadrado na região menos nobre de instalação do CD é sensivelmente inferior ao custo das lojas. As notações abaixo transcrevem esses cálculos.

\section{(i) Custo do espaço nas lojas}

O custo do espaço ocupado pelos estoques em cada loja $i$ é dado por:

$$
c^{t}-c^{t} M^{t}
$$

Onde: $C^{i}=$ custo do espaço na loja $i$

$$
c^{i}=\text { custo unitário do } \mathrm{m}^{2} \text { na loja } i
$$$$
M^{t}=\text { quantidade de } \mathrm{m}^{2} \text { necessária para estoque na loja } i .
$$ 


\section{(ii) Custo total do espaço das lojas}

Supondo que todas as $n$ lojas tenham o mesmo custo unitário $c$ por unidade de área e o mesmo espaço $M$ destinado a estoques, então, o custo total seria dado pela Equação 6:

$$
\mathrm{C}^{\mathrm{T}}=\operatorname{TH}_{\mathrm{C}} \mathrm{t}^{\mathrm{II}} \mathrm{M}^{*}
$$

\section{(Equação 6)}

\section{(iii) Custo total do espaço no CD}

Generalizando a racionalização de estoques, como discutido na Seção 3.2, o espaço total exigido no CD seria: $\sqrt{m} M^{t}$ e o custo deste espaço pode ser evidenciado com a resolução da Equação 7:

$$
C_{C D}^{T}=c^{C D} \sqrt{n} M^{t}
$$

Onde: $\mathbf{c}^{\mathrm{CD}}=$ custo unitário do $\mathrm{m}^{2}$ do $\mathrm{CD}$

Por outro lado, como $\sigma^{C D}<c^{i}$ e $\sqrt{n}<n$, segue-se que $C_{C D}^{T}<C^{T}$. Portanto, o custo correspondente ao espaço no CD torna-se inferior ao custo nas lojas devido à conjugação de dois fatores: a diferença de custos unitários do espaço e a redução do espaço agregado necessário.

O sistema com $\mathrm{CD}$, portanto, libera espaços nobres na cadeia, à jusante, na medida em que os pontos de venda reduzem seus espaços destinados à armazenagem e ampliam os espaços destinados à oferta de produtos. Ao transferir atividades de recepção e controle das lojas para um posto especializado, há também uma redução dramática dos espaços exigidos para estacionamento de caminhões, movimentação de carga e administração dos procedimentos de recepção de mercadorias. Essas iniciativas liberam espaços de custo elevado nos pontos de venda, em favor, também, de estacionamento para clientes. 


\subsection{4}

\section{Centralização de controles e redução de mão de obra nas lojas}

Outro fator preponderante na adoção dos CDs é a centralização dos controles, que consiste na verificação dos produtos entregues, na conferência de notas fiscais, na avaliação da qualidade do produto recebido e sua conformação com o pedido, entre outras. Essa centralização diminui a incidência de erros gerados pela multiplicidade das lojas.

O Centro de Distribuição em estudo é composto basicamente por duas áreas, a comercial e a operacional. A área comercial cuida do atendimento aos clientes, e fornecedores, e a área operacional cuida de toda a logística das entregas e do funcionamento do Centro de Distribuição.

A partir de dados primários, o salário médio de um operador de empilhadeira/operador logístico é de aproximadamente R\$ 1.300,00/mês. Um fato relevante é que, levando em consideração uma margem de segurança operacional, é necessário ter um funcionário operacional para cada $100 \mathrm{~m}^{2}$ de área, portanto, o CD da empresa estudada emprega aproximadamente 450 funcionários operacionais.

Todos os controles ficam centralizados no $\mathrm{CD}$ que, devido ao ganho de escala, provoca redução no número de pessoas envolvidas, além de maior precisão do desempenho, gerando assim um número menor de erros, conjugado com redução de custos. Esse ganho de produtividade provoca reduções de custos para a empresa, ao transferir para o CD atividades feitas anteriormente pelas lojas.

A tecnologia da informação é uma grande aliada neste processo, pois os ERPs - Enterprise Resource Planning - ajudam na integração dos diversos processos na empresa, deixando de lado os vários sistemas, caracterizados como “colchas de retalhos" dentro da organização. Além disso, um sistema ERP permite à empresa fazer uma revisão dos seus processos, eliminando atividades que não agregam valor.

O ERP ajuda ainda no processo de conferência e checagem dos materiais recebidos do $\mathrm{CD}$ nas lojas, devido à emissão de relatórios de consolidação das entregas, diminuindo o tempo utilizado em tal tarefa e liberando as pessoas para atividades mais estratégicas no ponto de venda. 
Entretanto, apesar de todos estes ganhos advindos com o Centro de Distribuição no que se refere à redução do custo da mão-de-obra, vale chamar a atenção para um problema brasileiro destacado pelo Instituto ILOS - Instituto de Logística e Supply Chain. Segundo o ILOS, o setor do varejo vem crescendo fortemente desde 2008 e grande parte desse movimento é proporcionada pela expansão do mercado interno. Mas a falta de profissionais capacitados a atuar no ramo tem se apresentado como uma restrição.

Atualmente há cada vez mais tecnologia envolvida nos processos organizacionais e a maioria das pessoas não está preparada para tal, necessitando de investimento por parte da empresa para capacitá-las. Não é possível sequer estimar o total de vagas de que o setor necessita para ficar competitivo.

Para o Centro de Distribuição estudado, supõe-se que a loja $i$ de varejo opere com $F^{i}$ funcionários, ao custo unitário $p^{i}$, ocupe uma área $M^{t} \mathrm{~m}^{2}$ e uma fração $\alpha \%$ desta mão de obra esteja alocada para trabalhos de recebimento, conferência, armazenamento e movimentação de mercadorias. Desta forma, havendo $n$ lojas e supondo uma relação fixa entre o custo unitário da mão de obra $p^{i}$ em cada loja e a força de trabalho em cada loja envolvida com a recepção e controle de produtos, pode-se representar o custo de mão de obra relacionada aos controles, no conjunto I das lojas por meio da Equação 8:

$$
C_{\text {MO }}=\alpha \sum_{i=1} p^{t} F^{t}
$$

(Equação 8)

Ao se transferir todas as atividades de recebimento, controle, guarda de produtos para o $\mathrm{CD}$, os custos envolvidos passam a ser conforme a Equação 9:

$$
C \mathscr{R O}_{O}=\frac{\sqrt{n}}{n} \alpha \sum_{i=1} p^{t} F^{t}
$$

Caso todas as lojas sejam idênticas em tamanho e dados operacionais, como funcionários e custos envolvidos, a equação 9 torna-se:

$$
C_{R Q}=\frac{\sqrt{n}}{n} \propto \cdot p^{i} F^{t}
$$


As equações acima evidenciam que a centralização dos estoques em um CD promove a redução do custo com mão de obra de apoio nas lojas.

\subsection{5}

\section{Redução da incidência da falta de produto}

Vale lembrar que os custos associados à falta de produtos estão diretamente ligados ao nível de serviço atingido. Apesar de sua grande importância, tais custos muitas vezes são ignorados pela dificuldade inerente a sua determinação. $O$ custo da falta de um produto costuma ser normalmente mensurado por meio da margem de contribuição de cada venda perdida por indisponibilidade do mesmo, ou seja, o quanto a empresa deixa de ganhar por não atender a uma demanda existente. Para casos de produtos com alta margem, o custo da falta tende a ser bastante significativo, impactando muitas vezes no nível de estoque desejado.

As tecnologias ora existentes têm como objetivo proporcionar às empresas em geral uma vantagem competitiva através da utilização de bancos de dados disponibilizados por seus parceiros, permitindo uma rápida e precisa tomada de decisão. Desta forma, os EDIs tem papel fundamental para algumas lojas de varejo onde seus fornecedores conseguem visualizar, no momento da venda, a necessidade de reposição dos estoques no cliente. Assim, a falta de produto fica minimizada, sendo, porém de fundamental importância saber mensurar tais custos.

Com a adoção de CDs, a falta de produto tende a diminuir consideravelmente, elevando assim o nível de serviço percebido pelo consumidor, visto que o abastecimento das lojas segue a política já citada $D+k$, onde $k=1,2$ ou 3.

Cabe lembrar um importante resultado oferecido pela Estatística. Se a demanda de uma loja $\boldsymbol{i}$ tem demanda $D_{i}$ e variância $\sigma_{i}^{\bar{z}}$, ao serem somadas todas as lojas, as características da demanda conjunta são:

a) Demanda conjunta $\rightarrow \mathrm{D}=\sum_{i=1}^{n} D t$

Variância das somas $\rightarrow \operatorname{Var}=\sum_{=1}^{n} \sigma_{n}^{2}$ 
b) Caso as demandas de cada loja sejam independentes, então, a variância da demanda agregada seria dada pela simples soma das variâncias de cada loja. No caso mais comum, as demandas têm uma certa correlação e a expressão anterior deve ser modificada. Supondo-se $\rho_{u j}$ a correlação entre as vendas das lojas $i$ e $j$ e $d_{i}=\frac{D_{i}}{\overline{\boldsymbol{L}} D_{i}}$ a demanda relativa da loja $i$, segue-se:

$$
\sigma^{2}=\sum_{i=1}^{n} d_{i}^{2} \sigma_{t}^{2}+\sum_{\substack{n \\ j=1}}^{n} \sum_{j \neq i}^{n} d_{i} \rho_{i j} \sigma_{i} \sigma_{j} \quad \text { (Equação 10) }
$$

Portanto, no caso usual de haver correlação entre as demandas das lojas, a variância agregada resulta ser inferior à simples soma das variâncias, enquanto que o desvio-padrão seria muito inferior ao que se esperaria ao considerar cada loja separadamente. A implicação é que, ao agregar os estoques em um $\mathrm{CD}$, qualquer política conservadora de estoque reduz em muito a probabilidade de falta do produto.

Relembrando a assertiva de Starr \& Miller (1962):

"the standard deviation of a sum of random variables goes up as the square root of the number of variables in the sum. This means that a given level of protection against demand fluctuations is relatively cheaper for a sum of such variables than it is if the same level of protection is maintained for each variable separately."

Comparando-se a frase dos autores com a expressão da variância acima, inferem-se duas afirmativas: i) se as demandas por cada loja forem correlacionadas, o que normalmente se espera, o desvio padrão da demanda centralizada será inferior ao desvio padrão de todas as lojas separadamente; e ii) dependendo do tipo de correlação, o desvio padrão da demanda agregada de todas as lojas poderá ser significativamente inferior ao da demanda descentralizada. 
$\mathrm{Na}$ sequência, este trabalho busca quantificar os principais ganhos que uma organização pode obter na implantação de um CD. A obtenção de custos unitários ocorreu de modo empírico, por sondagens na literatura e consulta a diversas organizações profissionais, ou seja, foram considerados volumes transacionados e custos unitários, ambos variando dentro de certos intervalos estimados. Esses ganhos econômicos estão subdivididos em cinco subseções, as quais consideram os fatores, citados neste capítulo, que proporcionam ganhos reais para a organização. 


\section{A Aplicação da Estrutura Analítica - Uma Empresa do Varejo Brasileiro}

Como este estudo tem o propósito de mensurar e evidenciar os principais ganhos de uma organização advindos da implantação de um $\mathrm{CD}$, tais reduções expressas em custos serão apresentadas a seguir.

Os custos unitários foram empiricamente obtidos através de pesquisa na literatura e entrevistas com diversos profissionais do mercado e da empresa focal Em geral, os dados foram obtidos sempre comparando duas variáveis, como por exemplo: volume de vendas $\mathrm{x}$ custo unitário; custo do frete $\mathrm{x}$ quantidade transportada, entre outros, fornecendo assim uma região válida de resultados.

A descrição e quantificação destes ganhos econômicos estão apresentadas neste capítulo, cobrindo os cinco itens considerados relevantes para este estudo, a saber: (i) redução nos custos de transporte originados dos fornecedores, (iii) a liberação de espaço nobre nas lojas para a exposição de mercadorias e estacionamento, (iv) redução de mão de obra devido a centralização dos controles dos produtos recebidos; e ( $v)$ redução da falta de estoque.

\section{1 \\ Quantificação dos ganhos decorrentes da implantação de um CD}

Nesta seção são evidenciados os ganhos obtidos pela rede quando da instalação do CD. A Figura 1, apresentada no Capítulo 1, demonstra os cinco pontos a serem destacados no presente estudo.

\subsection{1}

Redução no custo do transporte

Suponha, por exemplo, uma rede varejista que possua aproximadamente 100 lojas de varejo de tamanho e volume de vendas semelhantes, e 1.500 fornecedores. Na situação em que a distribuição é descentralizada, tem-se a 
hipótese de que os 1.500 fornecedores visitem as 100 lojas da rede de varejo 12 vezes ao ano, gerando um total de 1,8 milhões de viagens ao ano, predominantemente com volumes fracionados.

$\mathrm{Na}$ situação da distribuição centralizada, com a adoção de um Centro de Distribuição, o mesmo número de fornecedores (f), atendendo ao CD uma vez a cada mês, ou 12 vezes ao ano, totalizariam $12 \mathrm{f}=18.000$ viagens com cargas consolidadas. Imaginando o CD abastecendo as lojas a ele atribuídas, a cada dia, 300 dias do ano, teríamos um total de $100 \times 300=30.000$ viagens de curta distância com cargas fracionadas. Portanto, o sistema proposto sugere a redução de 1.800.000 viagens anuais, normalmente longas, por 48.000 viagens, das quais 18.000 sobre trajetos longos com cargas consolidadas, mais 30.000 viagens sobre trajetos tipicamente curtos.

Acrescentem-se ainda as viagens de retorno (+ 30.000 viagens), das lojas ao $\mathrm{CD}$, onde são enviados os produtos oriundos de eventual devolução para que o $\mathrm{CD}$ centralize e gerencie tais itens junto a cada fornecedor.

Baseado em dados coletados em duas empresas de transporte, a Tabela 3 mostra o preço médio de frete/tons em reais. Nestes preços há a referência de duas outras variáveis: km percorrido e tamanho do caminhão. Estes valores referem-se a viagens da região de origem das empresas fornecedoras até o $\mathrm{CD}$ do varejista, do CD para as lojas e vice-versa.

Tabela 3 - Preço médio de frete $(\mathrm{R} \$)$.

\begin{tabular}{|l|l|l|}
\hline $\begin{array}{l}\text { Fornecedor para as lojas } \\
\text { (entrega descentralizada) } \\
\text { Caminhão pequeno } \\
\text { trajetos longos }\end{array}$ & $\begin{array}{l}\text { Fornecedor para o } \\
\mathrm{CD} \\
\text { (entrega } \\
\text { centralizada) } \\
\text { Carreta / trajetos } \\
\text { longos }\end{array}$ & $\begin{array}{l}\text { CD para as lojas } \\
\text { (entrega centralizada) } \\
\text { Caminhão pequeno } \\
\text { trajetos curtos }\end{array}$ \\
\hline $\begin{array}{l}\mathrm{R} \$ 522,75 / \text { ton } \\
\text { Capacidade Max.: } 5 \text { tons }\end{array}$ & $\begin{array}{l}\mathrm{R} 142,57 / \text { ton } \\
\text { Capacidade Max.: } \\
23 \text { tons }\end{array}$ & $\begin{array}{l}\mathrm{R} \$ 138,94 / \text { ton } \\
\text { Capacidade Max.: } 5 \text { tons }\end{array}$ \\
\hline
\end{tabular}

Fonte: Empresas de transporte 


\section{Memória de cálculo para a redução do custo:}

$\underline{\text { Sistema Descentralizado (Fornecedores para as lojas) }}$

$\mathrm{R} \$ 522,75 \times 5$ tons $\times 1500$ fornecedores $\times 100$ lojas $\times 12$ visitas no ano $=$

$\mathrm{R} \$ 4.704 .750 .000,00$

Sistema Centralizado (Fornecedores para o CD)

$\mathrm{R} \$ 142,57 \times 23$ tons $\times 1500$ fornecedores $\times 1 \mathrm{CD} \times 48$ visitas no ano $=\mathrm{R} \$$ 236.095.920,00

$\underline{\text { Sistema Centralizado (CD para as lojas) }}$

$\mathrm{R} \$ 87,76 \times 5$ tons $\times 100$ lojas $\times 300$ visitas no ano + as viagens de retorno com as devoluções (300 visitas ao ano) $=\mathrm{R} \$ 41.682 .000,00$

\section{Total do sistema descentralizado: $\mathrm{R} \$ \mathbf{4 . 7 0 4 . 7 5 0 . 0 0 0 , 0 0}$}

Total do sistema centralizado: $\quad$ R\$ 277.777.920,00

Os valores da Tabela 2 permitem constatar que a redução no custo do frete é considerável.

De acordo com tal suposição é possível observar que, o custo total do frete no sistema descentralizado é em média $\mathrm{R} \$ 4,070$ bilhões, enquanto que no sistema proposto com $1 \mathrm{CD}$ ele passa a ser $\mathrm{R} \$ 262,423$ milhões, com uma queda porcentual de $94,07 \% \%$. Esse último valor refere-se a 60.000 viagen do $\mathrm{CD}$ às lojas vezes o custo médio aproximado de $\mathrm{R} \$ 440,00$ por viagem, somados ao custo médio de 72.000 viagens dos fornecedores ao $\mathrm{CD}$ no valor médio aproximado de R \$3.280,00 por viagem. O Gráfico 4 evidencia esta redução. 


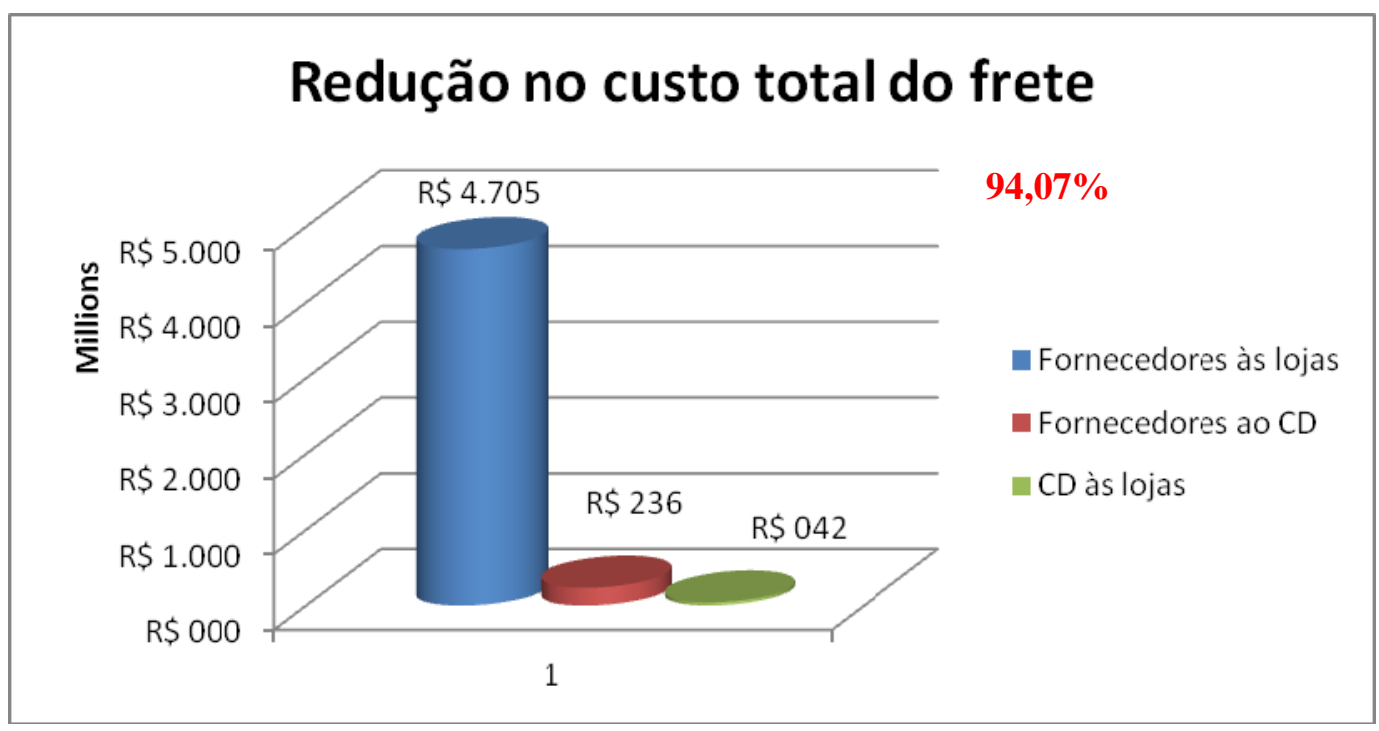

Gráfico 4: Redução no custo total do frete.

Fonte: A autora

\subsection{2}

\section{Redução no custo do estoque}

De acordo com o descrito na Seção 3.2 deste trabalho, a redução no custo do estoque após a centralização dos mesmos em um CD, é proporcional a $\sqrt{n}$. Vale ressaltar que o pressuposto para tal redução baseia-se na fórmula do Lote Econômico de Compras - LEC ou EOQ. Starr \& Miller (1962), e Heskett et al. (1974) já haviam escrito artigos relacionados ao tema, mas foi Maister (1976) que demonstrou tal redução para qualquer tipo de estoque e não somente dos estoques de segurança.

Usando como exemplo um produto vendido pela rede de varejo estudada, foi possível evidenciar o ganho descrito pelos autores acima. Os dados abaixo recebidos da empresa focal demonstram os custos envolvidos e a demanda anual do mesmo.

Demanda anual: 1000 unidades

Custo do pedido: $\$ 20,00$

Custo de armazenagem: 20\%

Custo por unidade: $\$ 5,00$

Lote Econômico: 200 unidades

Número de lojas: 100

Número de CD: 01 
Aplicando-se os valores acima na Equação 11, obtém-se o custo total de uma loja da rede:

$C T=\frac{D}{Q^{*}} \cdot A+\frac{Q^{*}}{2} \cdot h$

$$
\mathrm{CT}=\$ 5.200
$$

(Equação 11)

Obtém-se, por meio da Equação 12, o custo de todas as $n=100$ lojas da rede:

$$
C T_{n}=n \cdot C T
$$$$
\mathrm{CT}_{\mathrm{n}} \$ 520.000
$$

A Equação 13 evidencia o custo total com o estoque centralizado em um CD:

$$
\frac{C T_{C D}=\frac{n D}{\sqrt{n} \cdot Q^{*}} \cdot A+\frac{\sqrt{n} \cdot Q^{*}}{2} \cdot h=\frac{\sqrt{n} \cdot D}{Q^{*}} \cdot A+\frac{\sqrt{n} \cdot Q^{*}}{2} \cdot h}{\mathrm{CT}_{\mathrm{CD}}=\$ 6.108}
$$

A razão entre os dois custos (Custo Total das n lojas e Custo Total do CD), pode ser evidenciado pela Equação 14.

$$
\frac{n \cdot C T}{C T_{C D}}=\frac{n \cdot\left(\frac{D}{Q^{*}} \cdot A+\frac{Q^{*}}{2} \cdot h\right)}{\sqrt{n} \cdot\left(\frac{D}{Q^{*}} \cdot A+\frac{Q^{*}}{2} \cdot h\right)}=\sqrt{n}
$$

(Equação 14)

$$
=\$ 6.108 / \$ 520.000=\mathbf{8 5} \%
$$

Os resultados acima evidenciam o afirmado por Maister (1976) e evidenciam um ganho de $85 \%$ para o exemplo adotado, onde os estoques desta rede de varejo são alocados em um Centro de Distribuição ao invés de em 100 lojas. 


\subsection{3}

\section{Aumento do espaço nobre nas lojas}

Outro ganho considerável com a implantação de um CD refere-se ao aumento de espaço nobre nas lojas para exposição de produtos ao consumidor final, devido à transferência da administração de estoques para o CD. Com isso, o varejista libera espaço na ponta da cadeia - os pontos de venda - que antes era utilizado para recepção e armazenagem de produtos vindos dos fornecedores.

Com a liberação desta área de exposição nas lojas, é possível o aumento de faturamento para o estabelecimento ou a sua devolução ao locador, com a economia resultante. Levando-se em consideração que o valor do metro quadrado nos pontos de venda é bem mais alto do que o metro quadrado na região em que é estabelecido um $\mathrm{CD}$, uma redução significativa em custo é observada.

No exemplo estudado desta rede de varejo tais lojas utilizam uma média de $1.000 \mathrm{~m}^{2}$ de área para estoque/recepção de produtos. A área total necessária para armazenamento nos pontos de vendas estaria em torno de $100.000 \mathrm{~m}^{2}$. Admitindose que o número médio $1.000 \mathrm{~m}^{2}$ apresente uma pequena variação positiva ou negativa, a área necessária envolveria valores aproximados entre 80.000 a 100.000 $\mathrm{m}^{2}$.

Levando-se em consideração a informação do FIPE de que o preço médio do metro quadrado nas regiões onde se localizam as lojas gira em torno de R $\$$ 3.980,00, o custo total de oportunidade do espaço destinado aos estoques para as lojas representaria, em média, R\$ 398.000.000,00. Analisando agora a necessidade de uma faixa de 43.000 a $48.000 \mathrm{~m}^{2}$ para um Centro de Distribuição a um preço médio de $\mathrm{R} \$ 775,00 / \mathrm{m}^{2}$, o custo com armazenagem em um Centro de Distribuição representaria, em média, R\$37.200.000,00. O Gráfico 5 evidencia a redução de $90,65 \%$ nestes custos. 


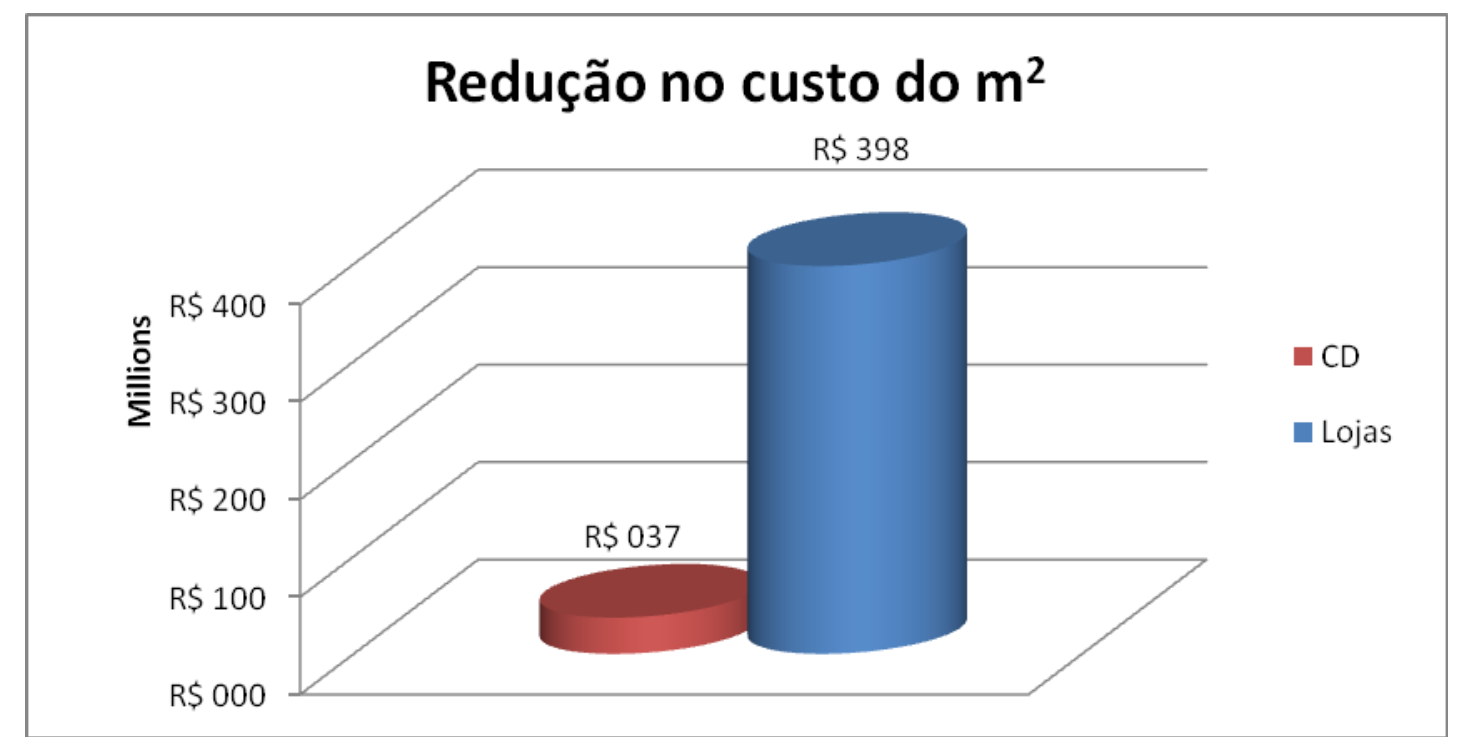

Gráfico 5 - Redução no Custo Total do $m^{2}$ nas lojas e nos CD’s. Fonte: A autora

Vale ainda lembrar que, com a transferência dos estoques para o $C D$, elimina-se nas lojas a necessidade de área destinada à manobra e espera de caminhões vindos de fornecedores, visto que os produtos já vêm conferidos e organizados do próprio $\mathrm{CD}$, bastando a simples recepção dos mesmos. Essa área liberada pode ser destinada a mais estacionamento para os clientes da loja ou retornada ao locador. As Figuras 14(a) e 14(b) ilustra a utilização dessas áreas antes e depois do CD. 

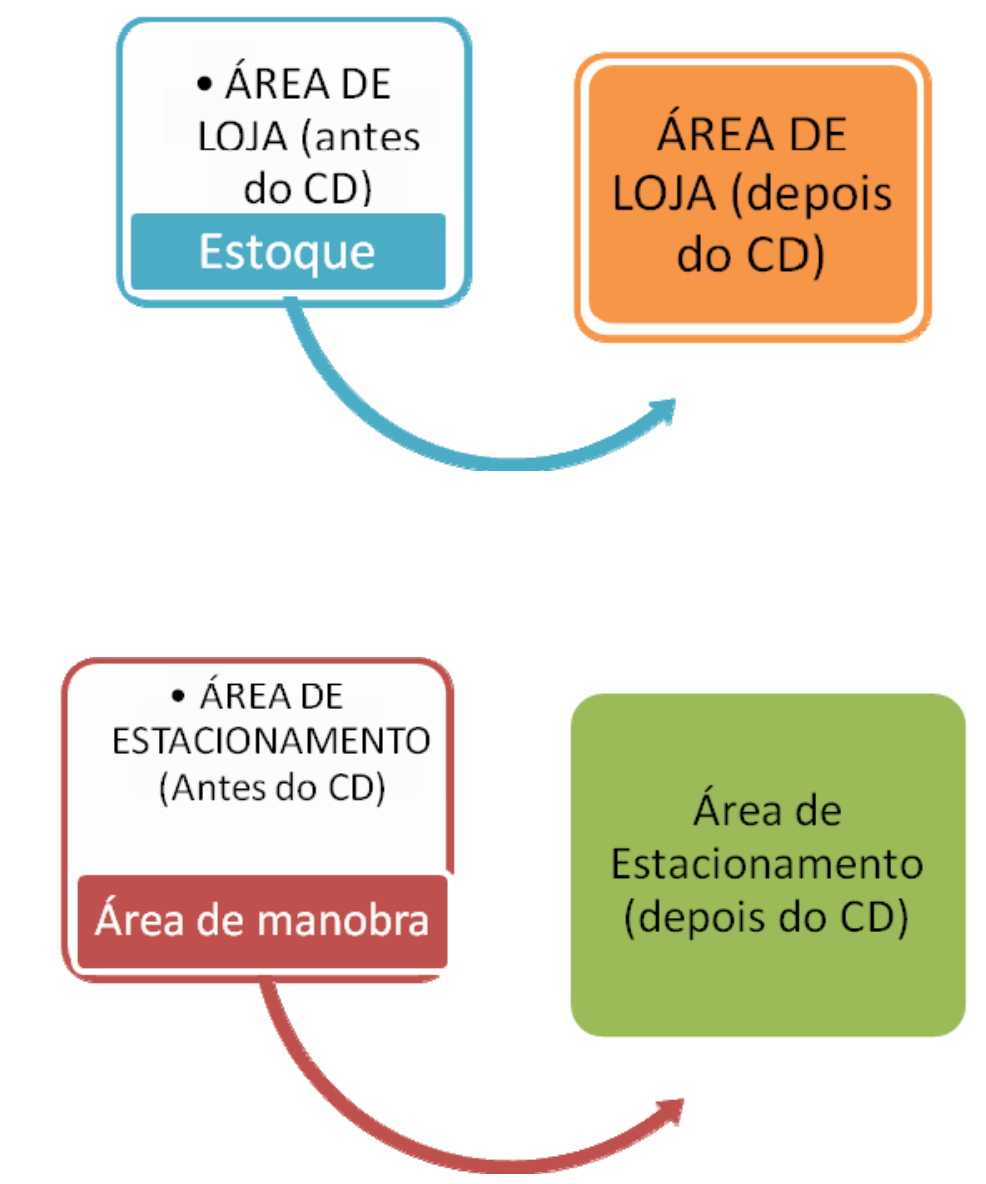

Figuras 13(a) e (b): Área de lojas e estacionamento antes e depois dos CDs. Fonte: A autora

\subsection{4}

\section{Redução do custo com mão-de-obra}

\section{(i) Redução no custo de MO de armazenamento}

O Centro de Distribuição é composto basicamente por duas áreas, a comercial e a operacional. A área comercial cuida do atendimento aos clientes, fornecedores e da gestão da empresa. A área operacional cuida de toda a logística das entregas e do funcionamento do Centro de Distribuição.

Conforme já citado, o salário médio de um operador de empilhadeira/operador logístico é de aproximadamente R \$ 1.300,00/mês. Como se faz necessário ter um funcionário operacional para cada $100 \mathrm{~m}^{2}$ de área, 
portanto, o $\mathrm{CD}$ da empresa emprega aproximadamente 450 funcionários operacionais.

Com a transferência de estoques para o Centro de Distribuição, o manpower envolvido na tarefa de recepção e armazenamento nas lojas também diminui, trazendo mais ganhos para a rede. A redução do número de pessoas com a centralização é bastante considerável. Nesta redução de manpower devem-se levar em consideração dois ganhos relativos à mão de obra: o ganho na redução do número de pessoas envolvidas com recepção de mercadorias nas diversas lojas que, com a adoção do $\mathrm{CD}$, não se fará mais necessária e, ainda, outro ganho que seria a redução de horas de trabalho de vários compradores nas diversas lojas.

O primeiro ganho, conforme já explicitado na Seção 3.5, diz respeito à redução com o pessoal envolvido na recepção e armazenagem de produtos, levando em consideração que já não haverá mais justificativa para que nas lojas existam funcionários dedicados exclusivamente a esta tarefa. Isto se fazia necessário quando a entrega era descentralizada.

Com o envio das mercadorias via $\mathrm{CD}$, tal tarefa é executada por um funcionário da loja que, apesar de possuir outra função, pode receber o caminhão vindo do CD uma vez por dia, sem prejuízo para o negócio, visto que as mercadorias já vêm separadas e conferidas.

Supondo que a quantidade de pessoas destinadas à recepção de mercadorias represente, em média, $10 \%$ do total de funcionários - para as 100 lojas tal porcentual representa, no total, aproximadamente de 750 a 1000 funcionários.

Levando em conta essas informações, o gasto anual com a área operacional, em um sistema centralizado, gira em torno de R $\$ 7.826 .00,00$.

- $\mathrm{R} \$ 1.300$ (salário) x 13 (meses) x 450(funcionários) = R \$ 7.605.000,00

- $\mathrm{R} \$ 1.300$ (salário) x 01 (mês) x 170 (funcionários) = R $221.000,00$

No sistema descentralizado, este gasto anual representaria aproximadamente:

- $\mathrm{R} \$ 1.300$ (salário) x 13 (meses) x 1000 (funcionários) = R \$ 16.900.000,00 
É importante citar que, com o aumento de demanda em determinadas épocas do ano, o quantitativo de funcionários do $\mathrm{CD}$ é acrescido de mais 170 pessoas. Mesmo com este acréscimo, o custo total de mão de obra destinada à recepção é reduzido em 49\% quando se passa de um modelo descentralizado para o centralizado. O Gráfico 6 evidencia esta redução de custo.

\section{(ii) Redução do custo de MO na adminitração de Compras}

Outro ganho refere-se à mão de obra dos compradores. Para tanto, tomemos por base uma condição hipotética de que todas as lojas da rede fazem contato diário com cerca de 10 fornecedores, seriam feitos 300.000 contatos ao longo de um ano (100 lojas x 10 fornecedores x 300 dias no ano). Ainda que tais pedidos sejam feitos por email, a centralização dos pedidos em um $\mathrm{CD}$ reduziria o número de horas de trabalho de vários compradores, podendo utilizar esta mão de obra para outros fins, reduzindo o número de transações ocorridas e, consequentemente, minimizando possíveis erros.

Vale lembrar ainda que, conforme Wanke et al. (2011), o advento de novas tecnologias de informação, como código de barra, EDI, internet, automação de PDVs, entre outras, trouxe vários benefícios inerentes à captura e disponibilidade de informações com maior grau de precisão e pontualidade. Pode-se destacar em particular a eliminação dos erros e o retrabalho no processamento de pedidos, fato esse que reduz consideravelmente os custos associados a esta atividade.

Há ainda uma redução da incerteza com relação à demanda futura, devido ao compartilhamento de séries de vendas para o cliente final por todas as empresas da cadeia. Com a disponibilização via TI das vendas coletadas em tempo real no varejo, tem-se um planejamento mais enxuto de diversas operações do fabricante. Isto também evita o chamado efeito chicote que causa impactos substanciais no planejamento de diversas operações em curto prazo, como programações de compras, produção, distribuição e dimensionamento dos estoques de segurança.

O CD tem uma área administrativa de aproximadamente $1.100 \mathrm{~m}^{2}$, empregando um total de 100 funcionários administrativos e comerciais. Usando também como base dados fornecidos pela empresa, o salário médio dos 
funcionários administrativos gira em torno de R\$ 2.500,00/mês. Portanto, o gasto anual com a área administrativa, no sistema centralizado, representa aproximadamente:

- 2.500 (salário) x 13 (meses) x 100 (funcionários) $=\mathrm{R} \$ 3.250 .000,00$

Levando em consideração que cada loja da rede tinha em seu quadro funcional, pelo menos, duas pessoas dedicadas à função de compras/comercial, tinha-se um quantitativo de 200 pessoas nas lojas. Portanto, no sistema descentralizado, este gasto anual representaria aproximadamente:

- 2.500 (salário) x 13 (meses) x 200 (funcionários) $=\mathrm{R} \$ 7.500 .000,00$

Logo, o custo anual total de manpower do centro de distribuição é de aproximadamente R $\$ 11.297 .000,00$, enquanto que no sistema descentralizado, as lojas teriam um custo anual total com manpower de aproximadamente $\mathrm{R} \$$ 24.400.000,00. O Gráfico 6 evidencia a redução de 53,7\%

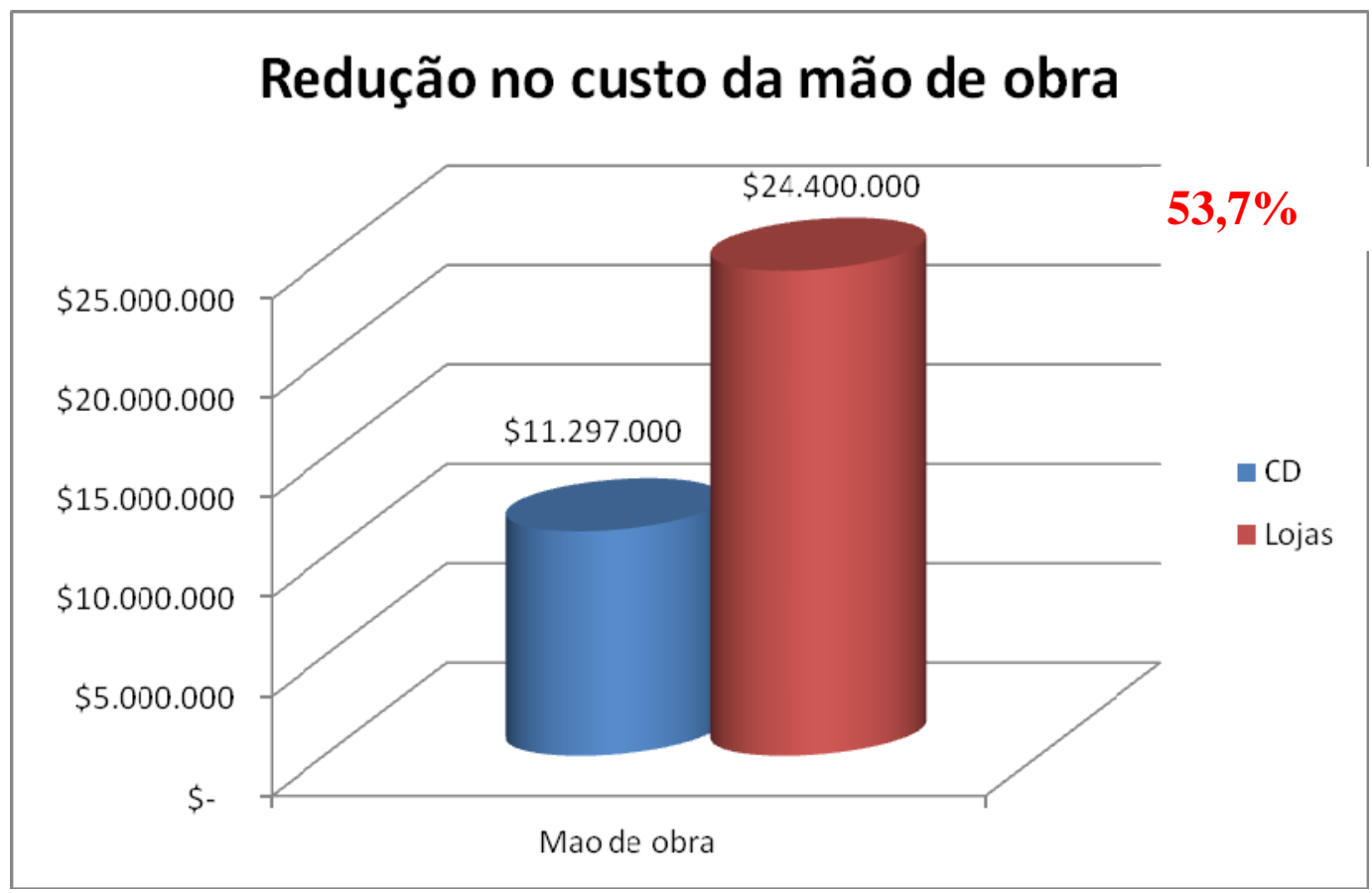

Gráfico 6 - Redução do custo de Mão de obra das Lojas x CD.

Fonte: a autora 


\subsection{5}

\section{Redução da falta de produto}

Quando os estoques de $n$ lojas são centralizados em um depósito, há uma redução de falta de produtos nos pontos de venda como decorrência do melhor gerenciamento dos níveis de estoque.

É bem verdade que os EDIs ajudam este gerenciamento na medida em que as necessidades de reposição são visualizadas em tempo real pelas lojas de uma rede de varejo e o seu Centro de Distribuição. Isto permite uma rápida reposição de estoques nos pontos de venda final, minimizando os custos e aumentando a percepção de nivel de serviço pelo consumidor.

Para evidenciar o que foi destacado por Starr \& Miller (1962) e Maister (1976), este trabalho obteve dados da empresa focal e construiu uma planilha que evidencia tal discussão.

Este produto é comercializado por todas as lojas da rede, com o qual foram feitos cálculos para determinação da correlação e variância para comprovar o que foi proposto pelos autores citados. Como as demandas das lojas demonstraram-se dependentes e existe certa correlação entre elas, o cálculo da variância adequa-se ao proposto pelos autores, e reforça o que está expresso na Equação 15, podendo ser evidenciado através do Anexo 1.

Foi adotado como exemplo um produto da linha higiene pessoal/Perfumaria, sendo esta linha a segunda em representatividade no estoque do Centro de Distribuição (14\%), ficando somente abaixo da linha de Brinquedos (24\%). A escolha deve-se também ao fato de não ter sido observada sazonalidade no consumo do produto, o que poderia levantar questionamentos quanto aos resultados.

Na Equação 15(a) pode ser observado que a fórmula está dividia em duas partes demonstrando a variância da demanda agregada dos produtos pontuando como a variância e o desvio-padrão são baixos. Na equação 16(a) a simples soma da variância das $n$ lojas pode ser encontrada e uma diferença de 96,27\% entre a demanda agregada e a simples soma das variâncias pode ser evidenciada. 


$$
\begin{gathered}
\sigma^{2}=\sum_{i=1}^{n} d_{i}^{2} \cdot \sigma_{i}^{2}+\sum_{i=1}^{n} \sum_{j=1}^{n} d_{i} \cdot d_{j} \cdot \rho_{i j} \cdot \sigma_{i} \cdot \sigma_{j} \\
\sum_{i=1}^{n} d_{i}^{2} \cdot \sigma_{i}^{2}+\sum_{i=1}^{n} \sum_{j=1}^{n} d_{i} \cdot d_{j} \cdot \rho_{i j} \cdot \sigma_{i} \cdot \sigma_{j} \\
=7.191,91+(1.220,364)=5.971,55 \\
\sum_{i}^{n} \sigma_{i}^{2}=160.296,75
\end{gathered}
$$

(Equação 16a)

Para evidenciar a redução do risco da falta de produto, foram avaliadas as demandas das 100 lojas atendidas pelo Centro de Distribuição ao longo do ano de 2011. Foi escolhida, de forma aleatória (por sorteio), uma amostra de tamanho 10, (Ver Anexo 1). Uma característica importante observada no produto escolhido é que o mesmo apresenta demandas independentes por loja e a demanda de uma loja não influencia na outra. No período estudado, percebe-se que há uma tendência decrescente da demanda, sem um motivo aparente que a justifique, conforme pode ser evidenciado no Gráfico 7.

Foram ainda feitos cálculos semelhantes para outro produto comercializado pela rede de varejo. A segunda bateria de cálculos aplica-se a um produto que oferece alta sazonalidade no mercado - refrigerante na versão lata $(350 \mathrm{ml})$ - e, mesmo assim, foi confirmado um porcentual baixo de risco para a centralização dos estoques.

Os resultados podem ser comprovados através das Equações 15(b) e 16(b)

$\mathrm{Na}$ Equação 15(b) pode ser observado que a fórmula está dividia em duas partes demonstrando a variância da demanda agregada dos produtos pontuando como a variância e o desvio-padrão são baixos. Na equação 16(b) a simples soma da variância das $n$ lojas pode ser encontrada e, uma diferença de 95,64\% entre a demanda agregada e a simples soma das variâncias pode ser evidenciada. 


$$
\begin{aligned}
& \sigma^{2}=\sum_{i=1}^{n} d_{i}^{2} \cdot \sigma_{i}^{2}+\sum_{i=1}^{n} \sum_{j=1}^{n} d_{i} \cdot d_{j} \cdot \rho_{i j} \cdot \sigma_{i} \cdot \sigma_{j}= \\
& \sum_{i=1}^{n} d_{i}^{2} \cdot \sigma_{i}^{2}+\sum_{i=1}^{n} \sum_{j=1}^{n} d_{i} \cdot d_{j} \cdot \rho_{i j} \cdot \sigma_{i} \cdot \sigma_{j}= \\
& 23.240,20+9.469,57=32.709,77
\end{aligned}
$$

(Equação 15b)

$$
\sum_{i}^{n} \sigma_{i}^{2}=749.912,35
$$

(Equação 16b)

Através do Gráfico 8 é possível evidenciar a sazonalidade do segundo produto - refrigerante. Ambos os produtos foram analisados durante o mesmo período - ano de 2011.

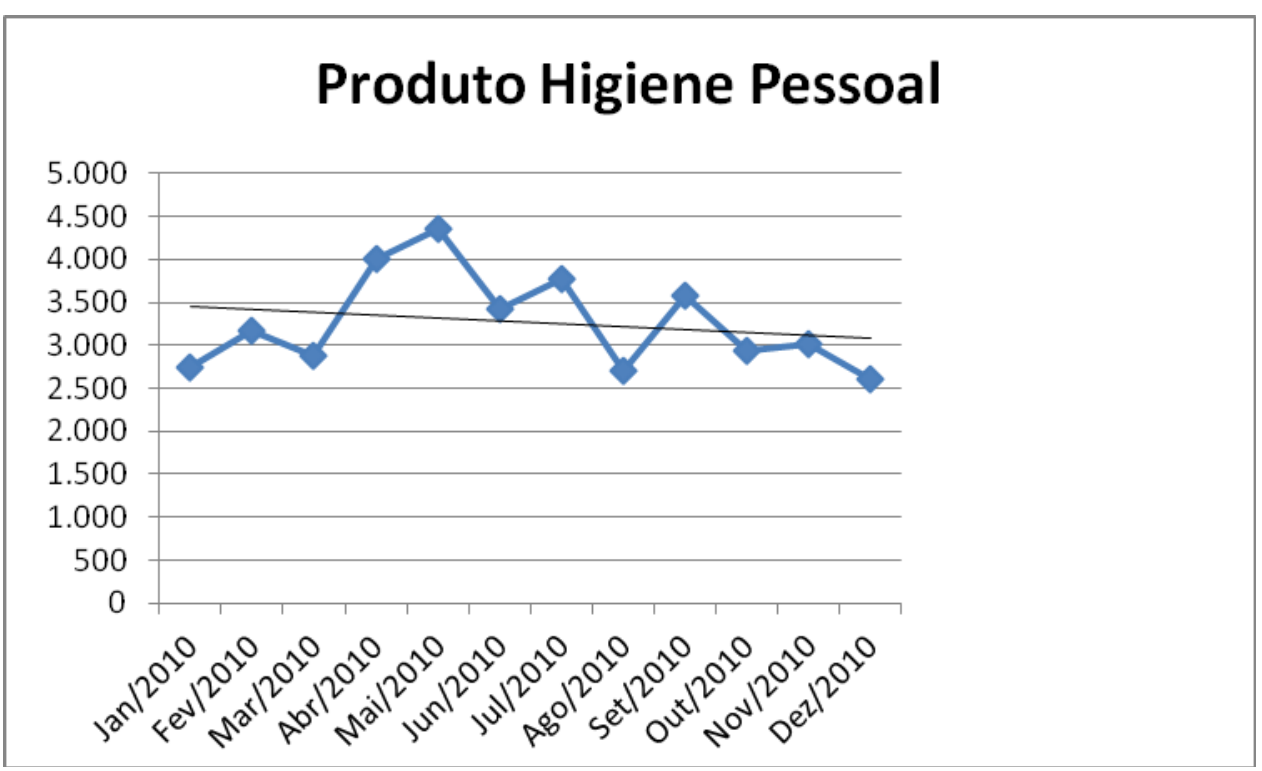

Gráfico 7: Comportamento da demanda anual do produto analisado (higiene pessoal). Fonte: Empresa estudada 


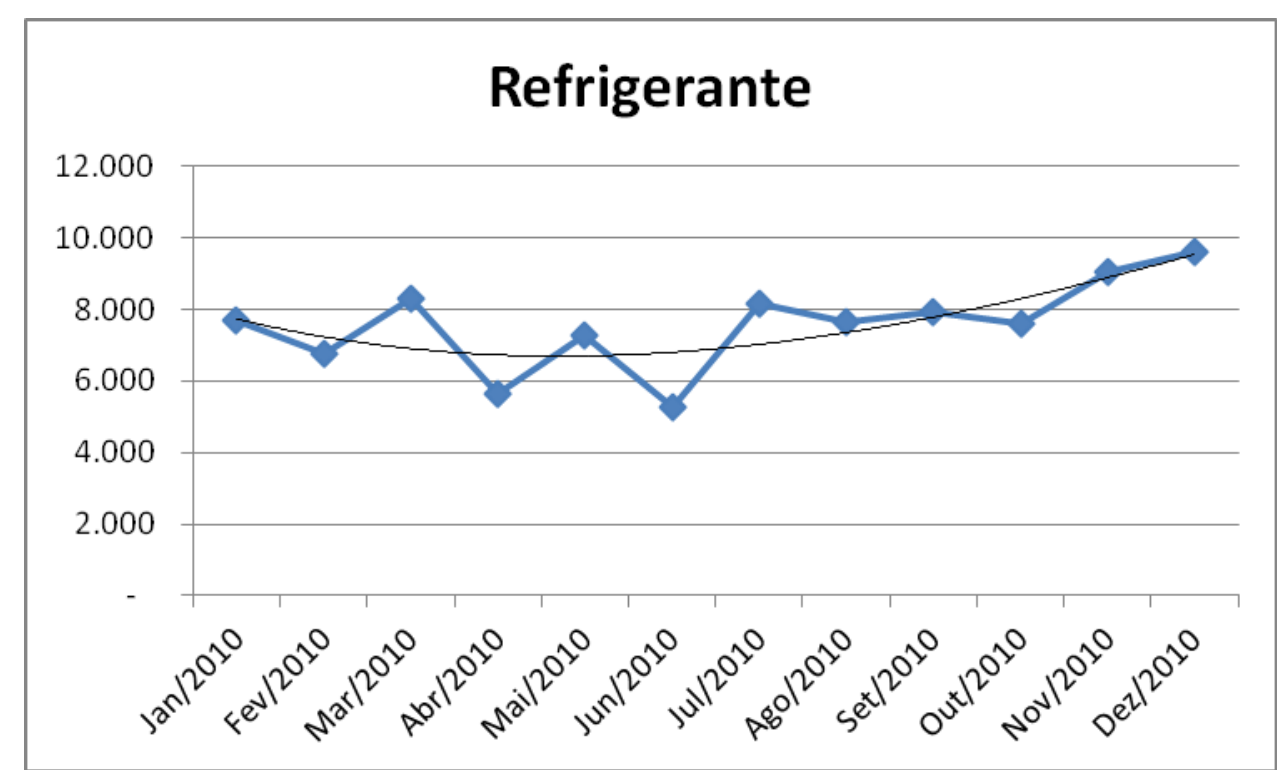

Gráfico 8: Comportamento da demanda anual do produto analisado (refrigerante). Fonte: Empresa estudada

Os Apêndices 1 e 2 também apresentam todos os cálculos de correlação que foram feitos, que confirmam que o risco na implantação de um Centro de Distribuição para esta rede de lojas, é muito pequeno. Isto se deve ao fato da variância da demanda agregada ser muito inferior à simples soma das variâncias das $n$ lojas da rede. Vale ressaltar ainda que havendo uma variabilidade pequena implica dizer que quanto menor esta o for, menor a variância e desvio padrão e, consequentemente, menor o risco desta centralização.

É importante ressaltar que o risco (desvio-padrão) da demanda agregada centralização -, não é uma média dos riscos (desvios-padrão) da demanda agregada de todas as lojas que integram a rede, pois a centralização o reduz. A centralização, no entanto, não é capaz de eliminar totalmente o risco, mas o minimiza consideravelmente.

Outras simulações quanto à correlação e desvio-padrão foram feitas, as quais evidenciaram que no caso das demandas das lojas não serem correlacionadas, o desvio padrão da demanda agregada mostra-se inferior ao desvio padrão de todas as lojas separadamente; e, ainda, havendo correlação, o desvio padrão da demanda agregada mostra-se significativamente inferior à demanda descentralizada, conforme afirmado por Starr \& Miller (1962); Maister (1976), e confirmando ainda, o Teorema do Limite Central de HALD (1952) 
O próximo capítulo consolida todos os ganhos advindos com esta centralização, trazendo ainda considerações importantes para a pesquisa. Sugere também pontos a serem desenvolvidos no prosseguimento de pesquisas pertinentes aos assuntos tratados neste estudo. 


\section{Conclusão e resultados obtidos}

O gerenciamento de estoques, incluindo sua localização, é um dos mais importantes assuntos da gestão contemporânea e altamente considerado pelos gestores. No desenho de uma cadeia de distribuição, a análise de itens como custos de estoque e de armazenagem, custos de transporte, custos da incidência da falta do produto, entre outros, deve ser avaliada na busca constante por reduções e/ou minimizações.

Neste contexto, a atenção se volta para as instalações de armazenagem e como elas podem contribuir para atender de forma eficiente as metas estabelecidas de nível de serviço. Um Centro de Distribuição tem papel importante dentro da logística, centralizando o estoque de toda a cadeia com o objetivo de obter vantagens tanto econômicas como em eficiência de processo.

A experiência e interesse do varejo em relação à adoção de Centros de Distribuição vêm aumentando de forma expressiva. Na realidade, uma boa parte das redes de lojas de departamentos, redes de supermercados, entre outras, criaram, nos últimos anos, seus Centros de Distribuição. Uma das principais questões está associada ao desempenho da Cadeia de Suprimentos no que tange ao trade off entre os níveis de serviços e o custo logístico total.

Entretanto, algumas empresas familiares ainda se opõem a esta prática não se beneficiando da redução de custos, simplesmente pelo fato de acreditar que o risco envolvido na implantação deste tipo de instalação, pode ser maior que os benefícios advindos com o mesmo.

Outras empresas simplesmente não adotam esta estratégia de distribuição por ainda não reconhecerem a importância e as melhorias advindas de um trabalho em parceria dentro das diversas camadas de sua Cadeia de Suprimentos, continuando a focar em soluções individuais e não sistêmicas.

Todavia, uma nova prioridade deve emergir para estas empresas e seus gestores no que diz respeito à busca por uma estratégia da Cadeia de Suprimentos que inclua a resiliência como palavra chave. 
Resiliência, entretanto, implica em flexibilidade e agilidade; implica em uma busca pela reconstrução contínua em renovação de processos que favoreçam sistematicamente a perpetuação da empresa.

Tais implicações se estendem não somente para além do simples redesenho de um processo na cadeia, mas para o estabelecimento de um relacionamento mais colaborativo na cadeia de suprimentos, baseado na transparência de informações. Estes são os maiores desafios para os líderes tanto da indústria quanto do varejo, que requerem especial atenção.

Outro ganho também importante da implantação de um Centro de Distribuição decorre da diminuição de problemas no transporte. Devido ao congestionamento das grandes cidades e a consequente restrição ao tráfego de caminhões pesados, como também à circulação e entrega de mercadorias em determinados horários, o sistema de CDs permite a racionalização desses processos e uma sensível redução no tráfego nas regiões urbanas centrais.

Em um momento em que o mundo necessita de ações que prezem pela manutenção de um meio-ambiente menos poluído - tanto no que se refere à qualidade do ar, quanto na diminuição do consumo de combustíveis poluentes $-\mathrm{a}$ centralização de estoques caminha na direção deste alvo, ainda que este fator não seja seu objetivo primeiro.

Vale lembrar que todos estes ganhos experimentados pelas grandes redes vêm sendo também compartilhados pelas pequenas redes, mediante o uso de depósitos públicos, de depósitos de propriedade de seu operador logístico ou do aluguel de módulos dentro de um condomínio logístico.

É evidente que a estratégia desta implantação passa, necessariamente, pela união de esforços para realizar uma distribuição mais eficiente e com menor custo, compartilhando a redução de custos e eliminando pontos de estrangulamento, vantagens estas derivadas do trabalho em parceria.

Ao longo da presente pesquisa foi possível evidenciar os ganhos obtidos quando da instalação de um Centro de Distribuição, em uma rede de varejo brasileira que atua na cidade do Rio de Janeiro. De uma distribuição descentralizada, a empresa passa a ter uma distribuição centralizada, minimizando diversos custos envolvidos em tal processo. 
Indo de encontro às questões-problema formuladas para esta pesquisa, foram avaliados os indicadores de redução de custos na implantação do Centro de Distribuição. Seus resultados confirmam que tais reduções são significativas quando da mudança de uma distribuição direta loja-a-loja para uma distribuição centralizada.

Os estudos realizados permitem também concluir que não existe, até o momento, nenhuma estrutura analítica, tal qual a apresentada neste trabalho, que consolide os cinco indicadores descritos na pesquisa, a saber: (i) redução dos custos do transporte originado nos fornecedores; (ii) redução dos volumes e custos de estoque; (iii) aumento de espaço nas lojas destinado à exposição de mercadorias e estacionamento; (iv) redução da mão de obra pela centralização dos controles sobre os produtos recebidos; e ( $v$ ) redução da incidência da falta de produto.

Da mesma forma foi possível confirmar que, apesar dos cinco indicadores, descritos anteriormente, terem sido extraídos de autores diversos, a estrutura analítica evidencia uma redução de custos expressiva para a Cadeia de Suprimentos, não alterando o resultado quando de sua consolidação.

Relatos de gestores ligados às Cadeias de Suprimentos do varejo indicam que a dinâmica do setor vai de encontro a uma busca por negociações constantes quando ocorre a centralização de estoques na rede. Uma das evidências destas negociações refere-se à redução do custo total do frete.

Como tal redução incide em porcentual maior sobre o fornecedor, conduzem-se negociações rigorosas quanto à diminuição nos preços dos fretes praticados aos varejistas e, ainda, o compartilhamento destas reduções de custos entre as empresas.

Como pode ser percebida, ao longo das evidências apresentadas no Capítulo 4, a redução nos custos de transporte e de armazenagem chama a atenção, pois tem uma representatividade muito grande no exemplo ora apresentado. De um custo de transporte de aproximadamente $\mathrm{R} \$ 4,7$ bilhões em uma distribuição descentralizada, a empresa passa a ter um custo de R\$ 278 milhões na centralização da distribuição, representando uma redução de 94,07\%.

Para este indicador foram utilizados dados primários, onde foi levada em consideração a diferença do modal utilizado, o percurso feito, a quantidade de 
viagens necessárias e, a quantidade de carga transportada. Vale ressaltar que o custo do transporte é reduzido também pelo fato de utilizarem-se caminhões com maior capacidade para uma distribuição centralizada.

No que diz respeito aos custos de estoque, foi possível identificar, com base no conceito proposto por Starr \& Miller (1962) e Maister (1976), que há uma redução a uma proporção de $\sqrt{n}$. No exemplo adotado, conforme apresentado na seção 4.3, tal redução representou um total de $85 \%$.

Uma redução observada como bastante significativa deve-se ao custo do $\mathrm{m}^{2}$ utilizado nas redes de loja. Como consequência da centralização, espaços nobres nas lojas são liberados para exposição de mercadorias e os estoques são transferidos para os Centros de Distribuição, posicionados, normalmente, na periferia dos grandes centros, onde $\mathrm{o}^{2}$ tem um valor bastante inferior. Esta redução de $90,65 \%$ pode ser comprovada nesta tese.

Outro aspecto que merece ser desatacado refere-se a redução do número de colaboradores envolvidos em um $\mathrm{CD}$, se comparado ao que se necessitava em uma rede de lojas para a tarefa de recepção e armazenagem. No exemplo utilizado foi possível constatar uma redução de aproximadamente $54 \%$ no custo total de mão de obra envolvida na distribuição direta loja-a-loja para uma distribuição centralizada.

Para evidenciar tal redução foi utilizada como base de cálculo a mão de obra da rede de lojas envolvida nas áreas de recepção/armazenagem, assim como na área de compras. O salário adotado para tais funções foi pesquisado na empresa estudada, bem como em uma pesquisa no mercado. Desta forma, um comparativo entre o recurso humano necessário para o modelo centralizado e descentralizado foi feito e a redução pode ser constatada.

No que se refere à redução do custo da falta de produto, esta pesquisa tomou como base dois itens vendidos pela rede, ao longo do ano de 2011, para constatar se haveria risco de falta do mesmo no processo de centralizados dos estoques.

Para ambos os casos - produto de higiene pessoal e refrigerante - foi possível evidenciar que o risco de haver falta de produto é pequeno, não representando ameaça para a centralização. Vale enfatizar que o produto refrigerante, apesar de ter como característica uma alta sazonalidade, também não 
apresentou riscos quando da transferência de uma estocagem descentralizada para centralizada.

Por meio dos Apêndices 1 e 2 foi possível ainda observar que devido à variância da demanda agregada ser muito inferior à soma das variâncias das $n$ lojas, comprova-se que o risco da centralização é reduzido e que a possibilidade de existir falta de produto no ponto de final de venda é bastante minimizada.

Concluindo, é importante lembrar que tais reduções de custo advindas da mudança de uma distribuição descentralizada para centralizada onde um Centro de Distribuição é instalado, requer a participação e dedicação com afinco de todos os gestores envolvidos em tal processo.

Existem evidências a partir das entrevistas feitas que o trabalho em prol da satisfação do cliente e do alcance dos objetivos organizacionais é perseguido por todos os níveis da organização, buscando assim satisfação também para a sociedade como um todo.

A tabela 4 demonstra os gastos da empresa focal antes e depois da implantação do Centro de Distribuição.

Tabela 4: Economicidade após instalação do CD.

\begin{tabular}{|cccc|}
\hline FATORES DE REDUÇÃO & ANTES DO CD & DEPOIS DO CD & $\begin{array}{c}\% \\
\text { Redução }\end{array}$ \\
\hline TRANSPORTE & $4.704 .750 .000,00$ & $277.777 .920,00$ & $\mathbf{9 4 , 0 7 \%}$ \\
\hline CUSTO ESTOQUE & - & - & $\sqrt{n}$ \\
\hline ÁREA DE ESTOCAGEM & $398.000 .000,00$ & $37.200 .000,00$ & $\mathbf{9 0 , 6 5 \%}$ \\
\hline MÃO DE OBRA & $24.400 .000,00$ & $11.297 .000,00$ & $\mathbf{5 3 , 7 0 \%}$ \\
\hline TOTAL & & & \\
\hline
\end{tabular}

Fonte: A autora 


\section{1}

\section{Contribuição da pesquisa}

Muitas pesquisas acadêmicas têm sido desenvolvidas sobre a otimização do processo logístico da cadeia de suprimentos, com o objetivo de alcançar a performance desejada por meio da minimização de custos e do atendimento dos níveis de serviços desejados. No entanto, este é um processo complexo que enfrenta uma série de desafios.

Devido à complexidade e aos altos custos envolvidos nas operações logísticas e à intensa competitividade entre as empresas do varejo brasileiro, é crescente o interesse da Academia e das organizações por este tema. A implementação de melhores técnicas logísticas tem demonstrado ser uma das mais interessantes áreas operacionais da administração pública e privada, onde o principal problema está associado ao desempenho da cadeia de suprimentos no que tange ao trade off entre os níveis de serviços e o custo logístico total.

Do ponto de vista acadêmico este estudo espera ter contribuído para as pesquisas relacionadas à redução nos custos logísticos por meio da otimização da cadeia de suprimentos; e para as pesquisas sobre o trade-off redução de estoques $\mathrm{x}$ aumento do nível de serviços, investigando a dinâmica das cadeias de suprimentos do varejo brasileiro.

Do ponto de vista corporativo este estudo espera ter dado subsídios à área de Logística das organizações no que diz respeito à redução dos custos logísticos com a adoção de Centros de Distribuição.

Os resultados da pesquisa constituem tanto avanços teóricos, quando comparado ao escopo de estudos anteriores, quanto gerenciais, seja no âmbito do varejo como da indústria, pois foi possível evidenciar a importância e impacto da implantação de um CD por toda a Cadeia de Suprimentos. Em particular, acreditase que a estrutura analítica utilizada pode ser aplicada tanto no varejo como na indústria, respeitando as características de cada setor e levando em consideração o momento vivenciado pelas empresas assim como pelo ambiente de negócios que as cercam. 


\section{2}

\section{Sugestões de prosseguimento da pesquisa}

Um trabalho de pesquisa nunca se esgota em si mesmo. Além de procurar responder a um questionamento, abre espaço para outros estudos. A presente tese não foge à regra.

Este trabalho baseou-se em evidências empíricas, juntamente com outras contidas em periódicos, livros e artigos. A partir das evidências contidas neste conjunto limitado, mas extenso de trabalho, foi possível evidenciar a redução dos custos através de uma estrutura analítica estabelecida pela autora.

O trabalho estabeleceu um modelo de redução de custos na cadeia de suprimentos, sob a ótica da empresa foco, auxiliando os gestores na confirmação de tais reduções nos indicadores propostos.

O modelo apresentado nesta pesquisa constitui-se como um passo em direção ao estudo de redução de custos, de maneira consolidada, em uma Cadeia de Suprimentos do varejo, sendo mais abrangente do que os estudados na literatura, pois agrupa um conjunto de indicadores.

A autora entende que uma das limitações prende-se ao fato do modelo ter sido aplicado somente na empresa foco, não submetendo o mesmo a outras camadas da referida Cadeia de Suprimentos para demonstração de redução dos custos, nem tampouco a outras segmentações de mercado.

Seria interessante também que futuros trabalhos buscassem evidenciar o quanto este modelo pode ser generalizável a outras realidades e se poderia ser aplicado à realidade de outros países.

Em particular, este modelo descritivo pode ser usado como evolução de outras discussões no que concerne a dificuldades práticas do varejo não abordadas neste trabalho, tais como: práticas gerenciais deste setor; práticas entre os parceiros (fornecedores e empresa foco); estratégias mercadológicas de impacto na cadeia de distribuição, entre outras.

Experimentos futuros devem ser conduzidos para complementar o quadro conceitual apresentado, sob diferentes condições das variáveis de controle: demanda do consumidor final, níveis de reposição de estoque, nível de satisfação do cliente, entre outras. 
Essa tese, bem como as questões aqui propostas, sinaliza a possibilidade de trilhar novos caminhos. 


\section{Referências bibliográficas}

BALLOU, R. Gerenciamento da Cadeia de Suprimentos, São Paulo, Bookman, 2001.

BARNEY, J.B.; HESTERLY, W. Administração Estratégica e Vantagem Competitiva: conceitos e casos, São Paulo, Pearson, 2011.

BOWERSOX, D.J.; CLOSS, D.J. Logistical management: the integrated supply chain process, New York, McGraw Hill, 1996.

BRANDEAU M.L.; CHIU, S.S. An overview of representative problems in location research. Management Science, v.35, p.645-674, 1989.

CALAZANS, F. Centros de Distribuição, Panorama Setorial, Gazeta Mercantil, 2001.

CENTRO DE ESTUDOS EM LOGÍSTICA - CEL - COPPEAD - UFRJ - 2012, Disponível em: http://www.cadetu.com.br/centrodelogistica. Acessado em: 08 mar, 2012.

CHING, H.Y. Gestão de Estoque na Cadeia Logística Integrada - Supply Chain, São Paulo, Atlas, 1999.

CHOPRA, S.; MEINDL, P. Gerenciamento da cadeia de suprimentos: estratégia, planejamento e operação, São Paulo, Pearson Education do Brasil Prentice Hall, 2004.

CHRISTOPHER, M. Logística e Gerenciamento da cadeia de suprimentos Estratégia para a redução de custos e melhoria dos serviços, São Paulo, Thomson \& Learning, 1992.

COOPER, M.C.; LAMBERT, D.; PAGH, J. Supply Chain Management: more than a new name for logistics, The International Journal of Logistics Management, v.8, n.1, p.1-14, 1997.

COSTA, J.C.; RODRIGUEZ, J.B.; LADEIRA, W.J. A gestão da cadeia de suprimentos: teoria e prática, XXV Encontro Nacional de Engenharia de Produção, Porto Alegre, 2005.

COUNCIL OF SUPPLY CHAIN MANAGEMENT PROFESSIONALS, CSCMP, Disponível em: http://cscmp.org/, acessado em 10, Out. 2011.

CROXTON, K.; ZINN, W. Inventory consideration in network design, Journal of Business Logistics, v. 26 n.1, p.149-168, 2005.

CURRENT, J. Discrete Network Location Models. in Drezner, Zvi e Hamacher. Facility Location: Applications and Theory. Springer Verlag, 2004. 
DASKIN, M.S.; COULLARD, C.R. An inventory-location model: formulation, solution algorithm and Computational Research. Annals of Operations Research. v.110, p.83-106, 2002.

DREZNER, Z.; HAMACHER, H.W. Facility Location : Application and Theory, Springer-Verlag, Berlin, 2001.

EFFROYSON, M.A.; RAY, T.L. A branch-and-bound algorithm for plant location, Operations Research, v.14, p.361-368, 1966.

EISELT, H.A.; LAPORTE, G. Objectives in Location Problems. in Facility Location : A Survey of Applications and Methdos, Zvi Drezner Editor, NewYork, Springer-Verlag Inc., 1995.

EPPEN, G.D. Effects of centralization on expected costs in a multi-location newsboy problem, Management Science, v.25, n.5, p.498-501, 1979.

EPPEN, G.; SCHRAGE, L. Centralized Ordering policies in a Multi-warehouse system with lead times and random demand, Management Science, v. 16, p.51$67,1981$.

ERLEBACHER, S,J.; MILLER, R.D. The interaction of location and inventory in designing distribution systems, IIE Transactions, v.32, p.155-166, 2000.

EVERS, P.; BEIER, F. The portfolio effect and multiple consolidation points: a critical assessment of the square root law, Journal of Business Logistics, v.14; n.2, p.109-125, 1993.

FARAHANI, R.Z.; HEKMATFAR, M. Facility Location: Concepts, Models, Algorithms and Case Studies: Contributions to Management Science. PhysicaVerlag Heidelberg, 2009.

FIPE - Fundação Instituto de Pesquisas Econômicas. Disponível em http://www.fipe.org.br. Acessado em 08 , mar, 2012.

GARDNER, J.T.; COOPER, M.C. Understanding shipper-carrier and shipperwarehouser relationships: partnerships revisited, Journal of Business Logistics, v.15, n.2, p.121-143, 1994

GIL, A.C. Como elaborar projetos de pesquisa, São Paulo, Atlas, 2009.

HAKIMI, S.L. Optimal Location of Switching Centers and the Absolute Centers and Medians of a Graph, Operations Research, v.12, n.3, p. 450-459, 1964.

HALD, A. Statistical Theory with Engineering Applications, New York, John Wiley \& Sons, 1952.

HESKETT, J.L. ; IVIE, R.M. ; \& GLASKOWSKY, N.A.Jr. Business Logistics, New York, Ronald Press, 1974.

IBGE - Market research - Disponivel em: www.ibge.org.br. Acessado em 15 de set, 2012. 
ILLES, A. Seeing sustainability in business operation: US and UK food retailer experiments with usual accountability, Business Strategy and the Environment, v.16, n.4, p.290-301, 2007.

ILOS; Disponível em: www.ilos.org.br, Acessado em 10, agosto, 2012.

KAPLAN, R.; NORTON, D. A estratégia em ação - Balanced Scorecard, Rio de Janeiro, Ed. Campus, Harvard Business School Press, 1997.

KOTLER, P. Administração de Marketing, Rio de Janeiro, Atlas, 1998.

KUEHN \& HAMBUERGER - A heuristic program for locating warehouses Management Science - v.9, n.4, p.643-666, Jul.1963.

LA LONDE, B.J.; COOPER, M.C. Partnerships in providing customer service: a third part perspective, Illinois, Council of Logistics Management, 1989.

LAMBERT, D.M.; COOPER, M.C.; PAGH, J.D. Supply Chain Management: Implementation Issues and Research Opportunities, The International Journal of Logistics Management, v.9, n.2, p.1-20, 1998.

; COOPER, M.C. Issues in supply chain management, Industrial Marketing Management, v.29, n.1, p.65-83, 2000.

. The Eight essential supply chain management process, Supply

Chain Management Review, v. 8, n. 6, p.18-26, set. 2004.

Supply Chain Management: process, partnerships, performance Supply Chain Management Institute, 2006.

LARSON, P.D.; HALLDORSSON, A. Logistics versus supply chain management: an international survey, International Journal of Logistics: Research and Applications, v.7, n.1, p.17-31, 2004.

LOVE, R.F.; MORRIS, J.G. and WESOLOWSKY, G.O. Facilities Location: Models and Methods, New York, North Holland, 1988.

MAISTER, D.H. Centralization of inventories and the square root law, International Journal of Physical distribution and Material Management, v. 6, n.3, p.124-134, 1976.

MARTINS, E. Avaliação de empresas: da mensuração contábil a econômica, Caderno de Estudos FEA/USP, n.24, Jul/Dez., 2000.

MARTINS, G.A.; THEÓPHILO, C.R. Metodologia da investigação científica para ciências sociais aplicadas, São Paulo, Atlas, 2009.

MCGOLDRICK, P.J. Retail Marketing, London, McGraw Hill, 2002.

MELLO, M.T. et al., Facility location and supply chain management - a review, European Journal of Operational Research, v.196, p.401-412, 2009. 
MINTZBERG, H.; LAMPEL, J.; QUINN, J.B.; GOSHAL, S. O processo da estratégia: conceitos, contexto e casos selecionados, São Paulo, 2003.

NEVES, J.L. Pesquisa Qualitativa: características, usos e possibilidades. Caderno de pesquisas em Administração, São Paulo, v.1, n.3, 1996.

NOZICK, L.K.; TURNQUIST, M.A. Integrating inventory impacts into a fixedcharge model for locating distribution centers, Logistics and Transportation Review, v.34, n.3, p.173-186, 1998.

PECK, H. Drivers of supply chain vulnerability: an integrated framework, International Journal of Physical Distribution \& Logistics Management, v. 35 , n.4, p.210-232, 2005.

PETERSON, R.; SILVER, E. Decision Systems For Inventory Management And Production Planning, New York, Wiley Sons, 1979.

PIRES, S.R.I. Gestão da cadeia de suprimentos (Supply Chain Management) conceitos, estratégias, práticas e casos, Rio de Janeiro, Atlas, 2004.

PORTER, M. Estratégia Competitiva, Rio de Janeiro, Atlas, 1981.

REESE, J. Solution Methods for the p-Median Problem, An Annotated Bibliography Networks. v.48, n.3, p.125-142, 2006.

REVELLE, C.S.; EISELT, H.A. Location Analysis: A Synthesis and Survey, European Journal of Operational Research, v.165, n.1, p.1-19, 2005.

RODRIGUES, E.F.; PIZZOLATO, N.D. Distribution centers to improve the supply chain efficiency and sustainability of the system. Annais do European Conference of Operational Research - Roma - 2013(a)

RODRIGUES, E.F.; PIZZOLATO, N.D. The economy of Distribution Center: the case of large retail network in Brazil, African Journal of Business Management, v.7, n.16, p.1541-1552, 2013(b)

ROZENTAL, M.; PIZZOLATO, N.D. Location of neighborhood shopping centers: A case study in Rio de Janeiro, Brazil - Revista del Instituto Chileno de Investigación Operativa, v.2, p.1-12, 2012.

RUMMLER, G.; BRACHE, A.P. Melhores desempenhos das empresas, São Paulo, Makron Books, 1994.

SCHARWZ, L.B. Physical Distribution: the analysis of inventory and location. AIIE Transactions, v.13, p.138-150, 1981.

SILVA, S.C. Um modelo de gestão para alinhamento da gestão do conhecimento ao Balanced Scorecard, Tese de Doutorado, UFSC, 2006.

SIMCHI-LEVI, D.; KAMINSKY, P.; SIMCHI-LEVI, E. Cadeia de suprimentos projeto e gestão, São Paulo, Bookman, 2003. 
SPIELBERG, K. Algorithm for the simple plant location problem with some side conditions - Operations Research - v.17, n.1, p.85-111, Jan-Fev. 1969.

STARR M.K.; MILLER D.W. Inventory Control: Theory and Practice, Englewood Cliffs, New Jersey, Prentice Hall, 1962.

VERGARA, S.C. Projetos e Relatórios de Pesquisa em Administração, Rio de Janeiro, Atlas, 2007.

WANKE, P.; FLEURY, P.F.; FIGUEIREDO, K.F. Logística empresarial: a perspectiva brasileira, Rio de Janeiro, Atlas, 2011.

WEBER Über der Standort der Industrien. 1. Teil : Reine Theorie des Standortes, Tübingen, Germany. English Translation: on the Location of Industries, Chicago, Univesity of Chicago Press, 1909.

ZINN, W.; LEVY, M.; BOWERSOX, D.J. (1989). Measuring the effect of centralization/decentralization on aggregated safety stock: the square root law revisited. Journal of Business Logistic. v.10, n.1, p.1-14, 1989. 
APÊNDICE 1 - DEMONSTRATIVO DE CORRELAÇÃO E VARIÂNCIA - PRODUTO HIGIENE PESSOAL

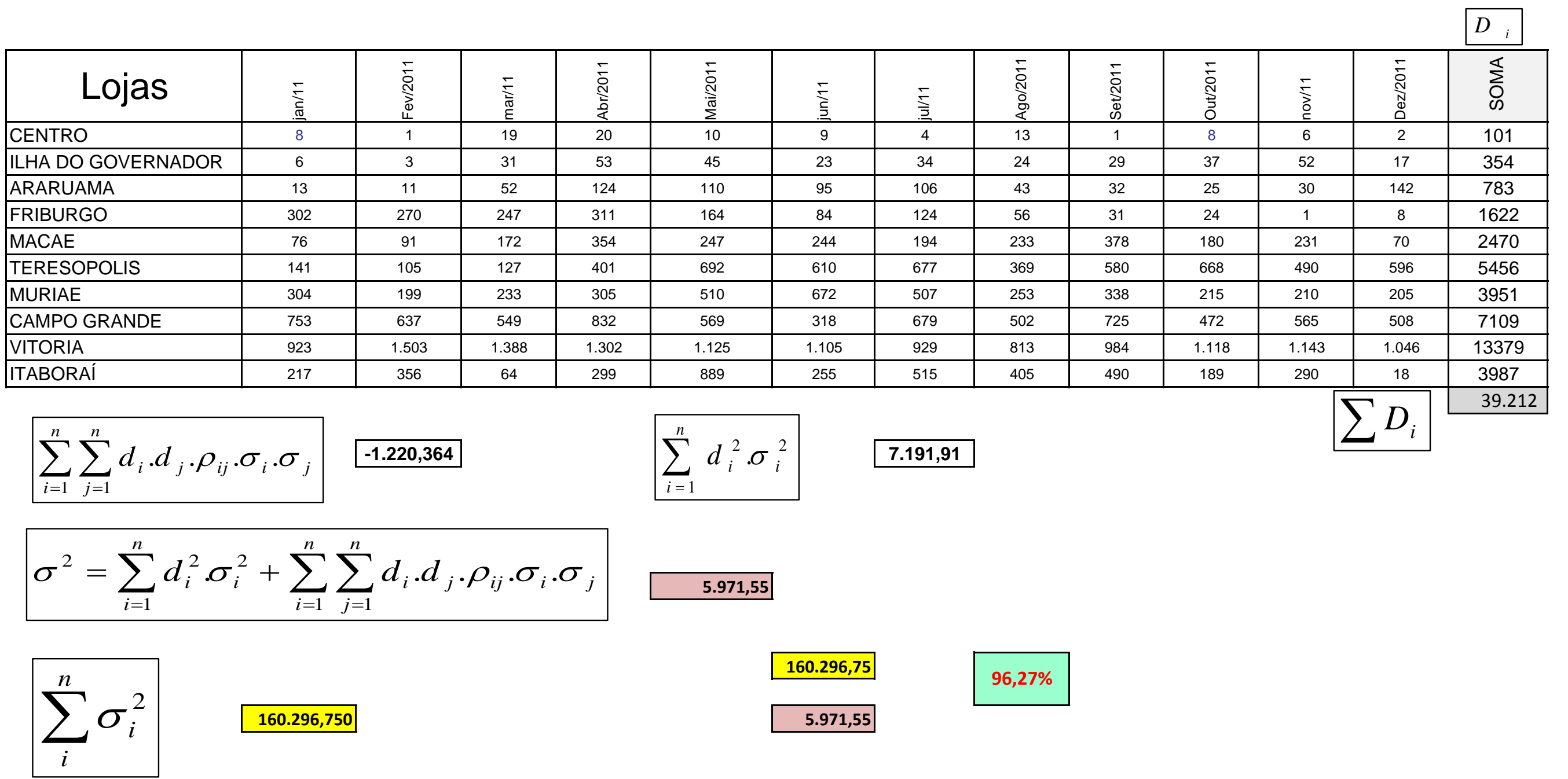


APÊNDICE 2 - DEMONSTRATIVO DE CORRELAÇÃO E VARIÂNCIA - PRODUTO REFRIGERANTE

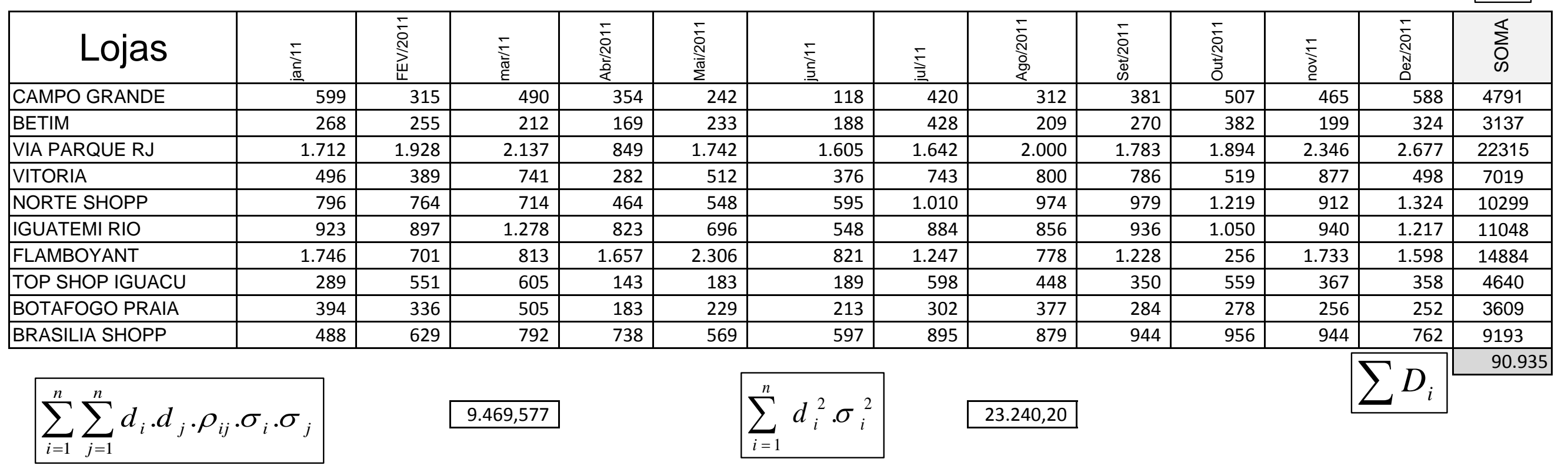

$$
\sigma^{2}=\sum_{i=1}^{n} d_{i}^{2} \cdot \sigma_{i}^{2}+\sum_{i=1}^{n} \sum_{j=1}^{n} d_{i} \cdot d_{j} \cdot \rho_{i j} \cdot \sigma_{i} \cdot \sigma_{j} 32.709,77
$$

$$
\sum_{i}^{n} \sigma_{i}^{2}
$$

